\title{
Correlation between irradiation and maxillary/mandibular bone vascularity, bone mineral density as well as implant stability = De samenhang tussen enerzijds radiotherapie en anderzijds vascularisatie van bot in de boven- en de onderkaak, botdichtheid en stabiliteit van implantaten
}

Citation for published version (APA):

Verdonck, H. W. D. (2008). Correlation between irradiation and maxillary/mandibular bone vascularity, bone mineral density as well as implant stability = De samenhang tussen enerzijds radiotherapie en anderzijds vascularisatie van bot in de boven- en de onderkaak, botdichtheid en stabiliteit van implantaten. [Doctoral Thesis, Maastricht University]. Datawyse / Universitaire Pers Maastricht. https://doi.org/10.26481/dis.20081218hv

Document status and date:

Published: 01/01/2008

DOI:

10.26481/dis.20081218hv

Document Version:

Publisher's PDF, also known as Version of record

Please check the document version of this publication:

- A submitted manuscript is the version of the article upon submission and before peer-review. There can be important differences between the submitted version and the official published version of record.

People interested in the research are advised to contact the author for the final version of the publication, or visit the DOI to the publisher's website.

- The final author version and the galley proof are versions of the publication after peer review.

- The final published version features the final layout of the paper including the volume, issue and page numbers.

Link to publication

General rights

Copyright and moral rights for the publications made accessible in the public portal are retained by the authors and/or other copyright owners and it is a condition of accessing publications that users recognise and abide by the legal requirements associated with these rights.

- Users may download and print one copy of any publication from the public portal for the purpose of private study or research. - You may not further distribute the material or use it for any profit-making activity or commercial gain

- You may freely distribute the URL identifying the publication in the public portal.

If the publication is distributed under the terms of Article $25 \mathrm{fa}$ of the Dutch Copyright Act, indicated by the "Taverne" license above please follow below link for the End User Agreement:

www.umlib.nl/taverne-license

Take down policy

If you believe that this document breaches copyright please contact us at:

repository@maastrichtuniversity.nl

providing details and we will investigate your claim. 
Correlation between irradiation and maxillary/mandibular bone vascularity, bone mineral density as well as implant stability 
ISBN 9789052787855

(C) Henk W.D. Verdonck

Cover: Geertjan van Zonneveld

Printed by: Datawyse | Universitaire Pers Maastricht

\section{Acknowledgement}

The author is grateful to Biocomp Industries (Vught, The Netherlands) for their support from start to finish 


\section{Correlation between irradiation and maxillary/mandibular bone vascularity, bone mineral density as well as implant stability}

\section{De samenhang tussen enerzijds radiotherapie en anderzijds vascularisatie van bot in de boven- en de onderkaak, botdichtheid en stabiliteit van implantaten}

\section{PROEFSCHRIFT}

ter verkrijging van de graad van doctor aan de Universiteit Maastricht op gezag van de Rector Magnificus, Prof. mr. G.P.M.F. Mols volgens het besluit van het College van Decanen, in het openbaar te verdedigen op donderdag 18 december 2008 om 10.00 uur

$$
\text { door }
$$

Henricus Wilhelmus Dymphena Verdonck geboren 28 april 1955 te Valkenswaard

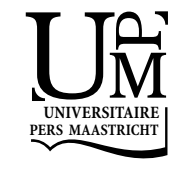




\section{Promotores}

Prof. dr. P.J.W. Stoelinga, Radboud Universiteit Nijmegen

Prof. dr. C. de Baat, Radboud Universiteit Nijmegen

\section{Copromotor}

Dr. G.J. Meijer, Radboud Universiteit Nijmegen

\section{Beoordelingscommissie}

Prof. dr. dr. P.A. Kessler, voorzitter

Dr. J.M.A. de Jong

Prof. dr. B. Kremer

Prof. dr. G.M. Raghoebar, Rijksuniversiteit Groningen

Prof. dr. D. Wismeijer, Academisch Centrum Tandheelkunde Amsterdam 


\section{Contents}

\section{Chapter 1}

$\begin{array}{ll}\text { General introduction and aim of the studies } & 7\end{array}$

1.1 Introduction 8

1.2 Implants in head and neck cancer patients $\quad 10$

$\begin{array}{ll}1.3 & \text { Radiotherapy and implant placement } \\ 11\end{array}$

1.4 Identifying the problem and assessment methods available 13

$\begin{array}{ll}\text { 1.4.1 Quantitative computed tomography } & 13\end{array}$

$\begin{array}{ll}\text { 1.4.2 Resonance frequency analysis } & 14\end{array}$

1.4.3 Laser Doppler flowmetry 14

$\begin{array}{ll}1.4 .4 \text { Intensity modulated radiotherapy } & 15\end{array}$

1.5 Objectives 16

1.6 Hypotheses 16

\section{Chapter 2}

Assessment of vascularity in irradiated and non-irradiated maxillary and mandibular minipig alveolar bone using laser Doppler flowmetry 25

2.1 Introduction 26

2.2 Materials and methods $\quad 26$

$\begin{array}{lll}2.3 & \text { Results } & 30\end{array}$

2.4 Discussion 31

2.5 Conclusion 33

\section{Chapter 3}

Implant stability during osseointegration in irradiated and non-irradiated minipig alveolar bone: An experimental study 35

3.1 Introduction 36

$\begin{array}{ll}3.2 & \text { Materials and methods } \\ 3.3 & 37\end{array}$

$\begin{array}{llr}3.3 & \text { Results } & 39\end{array}$

3.4 Discussion 42

\section{Chapter 4}

Quantitative computed tomography bone mineral density measurements in irradiated and non-irradiated minipig alveolar bone: An experimental study

$\begin{array}{lll}4.1 & \text { Introduction } & 50\end{array}$

4.2 Materials and methods $\quad 51$

4.3 Results 53

4.4 Discussion $\quad 54$ 


\section{Chapter 5}

Assessment of bone vascularity in the anterior mandible using laser Doppler flowmetry

5.1 Introduction

5.2 Materials and methods

5.3 Results

5.4 Discussion

\section{Chapter 6}

Intensity-modulated radiation therapy for oropharyngeal cancer:

Radiation dosage constraint at the anterior mandible

6.1 Introduction

6.2 Materials and methods

6.3 Results

6.4 Discussion

\section{Chapter 7}

Summary and address to the aims

Conclusions and future perspectives

\section{Chapter 8}

Samenvatting en evaluatie van de doelstellingen 92

Conclusies en toekomstperspectief 


\section{CHAPTER 1}

General introduction and aim of the studies 


\subsection{Introduction}

The introduction of endosseous oral implants in the early eighties of the last century has brought about a revolution in dentistry, altering the approach of oral rehabilitation in both partially dentate and edentulous patients. Implants were, initially, particularly used to provide support for complete dentures. Later on, implants were also used for (single) tooth replacement. At present, implant dentistry has developed into a specialty, focusing on implant placement and the fabrication of suprastructures, such as overdentures, fixed or removable partial dentures, and single crowns. Implant-supported prostheses are a predictable treatment based on well-documented clinical research (Albrektson et al. 1981; Jemt et al. 1989; Adell et al. 1990; Hutton et al. 1995; Lindquist et al. 1996; Carlsson et al. 2004; Albrektsson and Wennerberg, 2005). Developments in the field of implant dentistry did also involve the study of improved bone-toimplant contact. (Lazarra et al. 1999).

Endosseous oral implants are nearly exclusively made of titanium, although prior designs used other materials, such as polycrystalline alumina (Tübingen implants), hydroxyapatite, and bioactive glass (Denissen et al. 1989; Quayle et al. 1989; De Wijs et al. 1994; Brook and Hatton, 1998). However, because of their brittleness and lack of strength, polycrystalline alumina, hydroxyapatite, and bioactive glass appeared to be less suitable to serve as prosthesis-bearing implants. New implants with some potential are zirconia implants, although they can currently not be recommended for routine clinical use (Wenz et al. 2008). Implants are supposed to integrate in the surrounding bone during approximately a 3months period. Titanium is a metal, but its surface is covered by a thin layer of titanium oxide, acting as a ceramic (Wataha, 1996; Schupbach et al. 2005). This property explains the good bony adaptation, widely known as "osseointegration", a term coined by Brånemark (Brånemark et al. 1969). The interaction between implant material and surrounding tissues is supposed to be fundamental in implant survival. The first Brånemark titanium implants had a machined surface, but soon roughened surfaces and coatings were introduced (Thomas et al. 1987; Carlsson et al. 1988; Buser et al. 1991, Pilliar, 1998).

Increased surface roughness enhances mechanical interlocking between the macromolecules of the implant surface and the alveolar bone, resulting in increased resistance to compression, tension and shear stress (Puleo and Nanci, 1999; Albrektsson and Wennerberg, 2004a). In 
an animal study the better result of a roughened surface was demonstrated in unloaded conditions, but not in loaded conditions (Vandamme et al. 2008). Implant coatings are deposited upon the implant surfaces under conditions precluding the incorporation of osteoinductive agents (LeGeros and Craig, 1993). Various roughening methods, implant coatings, and combinations of roughening methods and implant coatings have been developed ever since, such as sandblasting, acid-etching, oxidation, hydroxyapatite plasma spray, magnetron sputtered calcium phosphate, radio frequency magnetron sputtered pyrophosphate, titanium plasma spray, titanium dioxide blasting, fluoride-modified titanium dioxide blasting, carbonate-containing apatite, collagen type I (with chondroitin sulphate), and desoxyribonucleic acid (DNA) (Bornstein et al. 2008; Caulier, 1996; Van Dijk, 1997; Hulshoff, 1997; Vercaigne, 1999; Walboomers, 2000; Sul et al. 2001; Ter Brugge, 2002; Albrektsson and Wennerberg, 2004b; Bernhardt et al. 2005; Galli et al. 2005; Rasmusson et al. 2005; Schliephake et al. 2005; Hayakawa et al. 2006; Manders et al. 2006; Siebers, 2006, Yonggang, 2006; Berglundh et al. 2007; Van den Beucken, 2007; Glauser et al. 2007; Oates, 2007; Stadlinger et al. 2008).

More than 220 implant brands, produced by about 80 manufacturers, have been identified in 2003, without providing any clear directives to claims of alleged benefits of specific morphological characteristics (Jokstad et al. 2004). A comparison of different surfaces revealed no significant differences between moderately rough surfaces, such as blasted and etched, and oxidized surfaces (Al-Nawas et al. 2008). In recent years, the implant coating-producing technique has changed profoundly. At present, a method is developed of depositing calcium phosphate coatings under favourable conditions of temperature and $\mathrm{pH}$ and precipitating bioactive agents. Molecules are integrated in the inorganic latticework and are released gradually in vivo during layer degradation, enhancing the capacity of the coating to act as a carrier system of osteogenic agents, such as titanium dioxide and magnesium (De Bruijn et al. 1999; Ter Brugge, 2002; Knabe et al. 2004; Liu et al. 2004; Du et al. 2005; Sul et al. 2005; Sul et al. 2006a; Sul et al. 2006b). New potential bioactive coatings, such as chitosan and phosphatidylserine-based coatings, are currently studied (Merolli et al. 2006; Bumgardner et al. 2007).

The most favourable implant position should be dictated by the implant-supported prosthesis to be fabricated and not by the local availability of alveolar bone. When in the most favourable areas the alveolar bone volume is not satisfactory, bone augmentation should be contemplated in 
order to achieve the best possible environment for implant insertion (Cawood, 2007). The planning of implant insertion was greatly enhanced by the introduction of CT-based 3-dimensional computer planning. The technique uses the information provided by a CT scan for fabricating a surgical guide, produced by a rapid prototyping machine. First, a radioopaque "scan prosthesis" is produced, being a complete denture or acylic teeth simulating the position of the future denture. Next, a CT scan is made whilst the patient is wearing the "scan prosthesis". The CT data are imported into a software programme, for instance the Simplant $₫$ planning system (Materialise, Leuven, Belgium). Using the software programme, virtual implants can be placed in the most favourable position, using all information provided by the CT data. Subsequently, the implant positions determined have to be transferred to the patient. For that reason, a computer guided machine should fabricate an acrylic surgical guide indicating the determined implant positions. The method described improves implant insertion accuracy and predictability. It also provides the clinician insight in local bone density and local bone volume available.

\subsection{Implants in head and neck tumour patients}

Resection of head and neck benign or malignant tumours often results in severe facial disfigurement, functional limitations and psychosocial disorders. The facial defects are causing aesthetical problems mainly, whilst intra-oral defects may lead to considerable oral-function impairment. The rehabilitation efforts rely on the close collaboration between the surgeon resecting the tumour, the surgeon dealing with the reconstructive treatment, the radiation oncologist and the maxillofacial prosthodontist.

In the past, prosthetic reconstructions provided for patients with intraoral defects hardly contributed to their well being, simply because of the very limited oral function. Adequate chewing, especially for edentulous patients, was hardly possible because of lack of denture retention. The dentures were often worn for aesthetic reasons only. Significant steps forward in micro-vascular surgery have allowed for predictable restoration of oro-facial bony and soft tissue structures. Combined with adequate prosthetic mandibular rehabilitation using oral implants, varying degrees of improvement in aesthetics, speech intelligibility and swallowing have been noted (Marunick and Roumanas, 1999; Roumanas et al. 2006; Gbara et al. 2007). Prosthetic rehabilitation in cases of large maxillary 
defects can also be facilitated adequately, using oral implants placed in the remaining parts of the orofacial skeleton (Lorant et al. 1994). However, despite the progress made several studies have shown that after surgical and prosthetic rehabilitation the abilities of chewing, swallowing, and speech may still be slightly limited. Impaired or limited chewing capacity, swallowing as well as speaking have strong negative effects on quality of life (Schliephake and Jamil, 2002, Van Cann et al. 2005; Markkanen-Leppanen et al. 2006).

Prosthetic rehabilitation of facial defects attempts to restore the facial disfigurements and may not only improve function, but also self-esteem and quality of life. In the past, facial defects were covered by facial prostheses glued by adhesives. Sometimes, a pair of glasses was used, holding the prosthesis in place and providing some additional stability. Neither of these treatments was satisfactory or comfortable to the patients. At present, implants are also widely used in craniofacial prosthodontics (Schoen et al. 2001; Roumanas et al. 2002; Chang et al. 2005; Honda et al. 2005; Hooper et al. 2005; Toljanic et al. 2005; Cawood et al. 2006;). Implant-retained facial prostheses offer significant quality of life enhancement, when compared with adhesive-retained prostheses. The survival rates of the implants are at an acceptable level (Schoen et al. 2001; Roumanas et al. 2002; Chang et al. 2005; Honda et al. 2005).

\subsection{Radiotherapy and implant placement}

Patients suffering from malignant tumours in the head and neck region often have to undergo radiotherapy as an important part of their treatment. Irradiation has a pronounced effect on both the soft tissues and the underlying bone. Detrimental side effects of bone irradiation are hypoxicity, hypocellularity, and hypovascularity (Marx, 1983). The detrimental effects of irradiation on the regeneration of bone include decreased osteocyte numbers and suppressed osteoblast activity. (Dudziak et al. 2000). Capillaries appear to be most vulnerable, particulary in alveolar bone (Xie et al. 1998). As a consequence, implants placed in irradiated bone may have less implant-bone contact, which may result in early implant loss. The decreased implant-bone contact in irradiated bone has been shown in various histological studies (Grotz et al. 1999; Brogniez et al. 2000; Weinlaender et al. 2006). The decision whether to place implants in irradiated bone is currently mainly based on the irradiation dose 
received at the implant site. When the implant site has received more than 50 Gray (Gy), an increased risk of implant failure and other complications, such as osteoradionecrosis, are to be expected (Visch et al. 2002). It is questionable, however, whether the irradiation dose is the only parameter determining success or failure. A systematic review of the literature published between 1990 and 2006 showed similar failure rate for implants placed pre- and post-radiotherapy. All implant failures observed, occurred within 36 months post radiotherapy. Most failures occurred between 1 and 12 months after placement (Colella et al. 2007).

When irradiated bone is traumatized or exposed, for instance in case of tooth extraction or implant placement, it is also at risk of developing osteoradionecrosis. Osteoradionecrosis may even develop spontaneously, without a preceding surgical intervention. Yet, trauma is likely to be an important initiating factor of osteoradionecrosis and infection plays only a secondary role (Limm et al. 1999). Consequently, every surgical intervention, such as implant placement, carries a considerable risk. Therefore, it was recommended to place implants before radiotherapy (Schoen et al. 2004; Schepers et al. 2006). Yet, implant placement during the ablative surgery is not always possible or the best choice. Sometimes, implant placement is preferred after the reconstructive surgical treatment for several reasons. First, implants placed during the ablative surgical treatment are not always situated at the most favourable position, creating problems during the subsequent prosthetic treatment. These problems are predominantly due to the lack of proper orientation during the surgical treatment or due to the lack of communication with the prosthodontist during implant placement. When using composite grafts, also problems may appear with the implant surrounding skin and subcutaneous tissues. Second, especially during simultaneous bony reconstructions, immediate implant placement may lead to unfavourable implant positions because the orientation on the non-resected part of the jaw is often difficult. Orientation on the opposing jaw may even be more difficult (Teoh et al. 2005). When implants are placed in the time period between the ablative surgical treatment and the start of radiotherapy, it is recommended to allow a period of at least two weeks for initial implant integration.

Recent research projects have focussed on hyperbaric oxygen therapy, not only treating osteoradionecrosis, but also diminishing a post surgical risk of osteoradionecrosis, such as implant placement (Coulthard et al. 2003; Kanatas et al. 2005; Schoen et al. 2007; Gerlach et al. 2008). 
The results of these studies are not conclusive. Hyperbaric oxygen therapy was even found to be of little or no benefit on post radiotherapy implant placement (Schoen et al. 2007; Shaw et al. 2007).

\subsection{Identifying the problem and assessment methods available}

The deleterious effects of irradiation on bone have been recognized for almost a century and still continue to be a problem until today because of improved survival of patients treated with radiotherapy for oral and neck cancer (Cawood and Stoelinga, 2006; Weinlaender et al. 2006). Irradiation causes a spectrum of changes from mild osteopenia, through disordered wound healing with varying degrees of bone sclerosis to osteoradionecrosis (Zarem and Carr, 1983; Williams and Davies, 2005). Osseointegration of oral implants is dependent on many factors, for instance bone mineral density, bone vascularity, and initial implant stability (Devlin et al. 1998; Duyck and Naert, 1998; Amorim et al. 2006; Traini et al. 2006).

In irradiated patients, 4 methods would be of great significance in preventing early implant loss and osteoradionecrosis:

- a method assessing bone mineral density

- a method assessing implant stability for determining the appropriate time of implant loading

- a method assessing vascularity of intended implant recipient sites

- a method decreasing the irradiation dose of surrounding critical organs.

According to the literature described in the subparagraphs 1.4.1-1.4.4, appropriate methods for these assessment purposes could be:

- quantitative computed tomography (QCT)

- resonance frequency analysis (RFA)

- laser Doppler flowmetry (LDF)

- intensity modulated radiotherapy (IMRT).

\subsubsection{Quantitative computed tomography}

Bone mineral density is defined as mineral mass per unit volume (Rauch and Schoenau, 2001). Quantitative computed tomography provides a site-related measure of bone mineral density and is useful as a non- 
invasive method for determining bone quality prior to implant placement (Lindh et al. 1996; Shahlaie et al. 2004; Turkyilmaz et al. 2007). Significant correlations were found between bone density measurements provided by quantitative computed tomography and implant stability parameters (Turkyilmaz et al. 2007). Bone mineral density is calculated by measuring Hounsfield units and relating those values to a calibration bone phantom with a predetermined bone mineral density (Todisco and Trisi, 2005).

\subsubsection{Resonance frequency analysis}

A certain degree of implant stability is a prerequisite for long-term implant survival. Stability is defined as the stiffness of an implant placed in bone (Meredith et al. 1996). It has been suggested that resonance frequency analysis is a sensitive method, which may be used to detect even minor changes in the level of bone-implant contact (Sennerby et al. 2005; Huwiler et al. 2007). However, the method still has some uncertain issues (Atsumi et al. 2007). For instance, its suitability is questionable when applied on different implant systems (Rabel et al. 2007).

Resonance frequency analysis measures implant stability quantitatively and objectively by application of microscopic flexural stress. The response of a small transducer attached to an implant fixture or abutment is recorded (Meredith et al. 1997). Measured values are converted into an index known as implant stability quotient. Changes in the quotient are related to alterations of implant stiffness in the surrounding tissues. Resonance frequency analysis is usually showing a decrease of implant stability in the first month after implant placement, followed by an increase during the second and third month, suggesting an adaptive bone remodelling process around implants (Balshi et al. 2005).

\subsubsection{Laser Doppler flowmetry}

An appropriate method of assessing bone vascularity could be laser Doppler flowmetry. Modern laser Doppler flowmetry techniques are using a laser diode device producing a beam of near infrared laser light with an operating wavelength of 780 to $820 \mathrm{~nm}$, beaming into human tissues by a fiber optic connector. This light, hitting moving blood cells, undergoes a change in wavelength (Doppler shift), while the wavelength of the light hitting static structures is unchanged. A returning fibre in the probe picks 
up and carries the light back to a photo detector. The magnitude of the signal and the frequency changes are directly related to the relative number and velocity of blood cells in a recorded volume (Michelson et al. 1996; Wong, 2000; Bollinger and Partsch, 2003). Wong introduced the concept of laser Doppler flowmetry as a diagnostic tool verifying bone graft vitality, following a maxillary sinus grafting procedure. Six months after the grafting procedure, detection of blood flow in all graft sites indicated successful angiogenesis (Wong, 2000). In a previous study, laser Doppler flowmetry was used for recording microvascular blood flow in cancellous mandibular bone of young pigs (Hellem et al. 1983). Laser Doppler flowmetry has also been shown to be useful assessing bone vitality in osteomyelitis as well as in assessing pulp vitality and laser Doppler flowmetry can be helpful in many other applications (Swinotkowski et al. 1989; Duwelius and Schmidt, 1992; The, 2006; Von Arx et al. 2007). However, the method has not been demonstrated to be reproducible and no data are available on blood flow values in maxillary and mandibular bone of non-irradiated patients. These values may not only vary from person to person, but may also be depending on the individual amount of local residual alveolar bone.

\subsubsection{Intensity modulated radiotherapy}

New radiotherapy techniques, such as 3-dimensional conformal irradiation, intensity modulated radiotherapy, and proton therapy, are allowing better dose distribution with lower dose to the non-target organs (Jereczek-Fossa et al. 2003). Intensity modulated radiotherapy (IMRT) uses modifications in the intensity of the photon-beam from a linear accelerator across the irradiated fields to enhance dose conformation in three dimensions (DeLaney et al. 2005). IMRT can escalate the total dose and fractional dosage to target volumes and decrease the irradiation dose of surrounding critical organs. The radiation dose distribution to the mandible is rarely considered with IMRT and the potential risks of osteoradionecrosis or osseointegrated implant failure are not well defined (Parliament et al. 2005). By IMRT the mandible may receive a high dose of radiation, which could be a contra-indication for implant placement. 


\subsection{Objectives}

In this thesis four studies are described, which were designed to investigate the effects of irradiation on maxillary and mandibular alveolar bone in order to quantify these effects and to determine those bone conditions in which implants could be placed safely. The emphasis is on bone vascularity and bone mineral density since methods and instruments seem available for measuring these parameters prior to implant placement. One study was designed to investigate the possible better dose distribution with lower dose to the non-target organs by intensity modulated radiotherapy.

First objective of this study was to find a practical, reliable and reproducible method enabling the clinician to place implants in patients irradiated in the head and neck region, with a good implant survival rate and minimal risk of osteoradionecrosis. Second objective was to find a method avoiding a high radiation dose at the anterior interforaminal part of the mandible, using intensity modulated radiotherapy (IMRT).

\subsection{Hypotheses}

With regard to the objectives of this study five hypotheses were formulated.

- Laser Doppler flowmetry is an adequate, reproducible and reliable method for assessing maxillary and mandibular alveolar bone vascularity.

- Maxillary and mandibular alveolar bone vascularity is reduced in irradiated alveolar bone when compared to non-irradiated alveolar bone.

- Bone mineral density is increased in irradiated maxillary and mandibular alveolar bone, when compared to non-irradiated maxillary and mandibular alveolar bone.

- There are no differences in primary implant stability between implants in irradiated and non-irradiated alveolar bone. During osseointegration, implant stability is decreasing more pronounced in irradiated alveolar bone, when compared to non-irradiated alveolar bone, because of impaired alveolar bone vascularity in irradiated alveolar bone.

- Using IMRT, it is feasible to designate the anterior interforaminal part of the mandible as a critical area to spare with the objective to reduce radiation dose at this site and thus, increasing the implant success rate and diminishing the risk of osteoradionecrosis. 


\section{References}

Adell R, Eriksson B, Lekholm U, Brånemark PI, Jemt T. A long-term follow-up study of osseointegrated implants in the treatment of totally edentulous jaws. Int $\mathrm{J}$ Oral Maxillofac Implants 1990; 5: 347-359.

Albrektsson T, Brånemark PI, Hansson HA, Lindstrom J. Osseointegrated titanium implants. Requirements for ensuring a long-lasting, direct bone-to-implant anchorage in man. Acta Orthop Scand 1981; 52: 155-170.

Albrektsson T, Wennerberg A. Oral implant surfaces: Part 1 - review focusing on topographic and chemical properties of different surfaces and in vivo responses to them. Int $\mathrm{J}$ Prosthodont 2004a; 17: 536-543.

Albrektsson T, Wennerberg A. Oral implant surfaces: Part 2 - review focusing on clinical knowledge of different surfaces. Int J Prosthodont 2004b; 17: 544-546.

Albrektsson T, Wennerberg A. The impact of oral implants - past and future, 1966-2042. J Can Dent Assoc 2005; 71: 327a-d.

Al-Nawas B, Groetz KA, Goetz H, Duschner H, Wagner W. Comparative histomorphometry and resonance frequency analysis of implants with moderately rough surfaces in a loaded animal model. Clin Oral Impl Res 2008; 19: 1-8.

Amorim MA, Takayama L, Jorgetti V, Pereira RM. Comparative study of axial and femoral bone mineral density and parameters of mandibular bone quality in patients receiving dental implants. Osteoporos Int 2006 17: 1494-1500.

Atsumi M, Park S-H, Wang H-L. Methods used to assess implant stability: current status. Int J Oral Maxillofac Implants 2007; 22: 743-754.

Balshi SF, Allen FD, Wolfinger GJ, Balshi TJ. A resonance frequency analysis assessment of maxillary and mandibular immediately loaded implants. Int $\mathrm{J}$ Oral Maxillofac Implants 2005; 20: 584-594.

Berglundh T, Abrahamsson I, Albouy J-P, Lindhe J. Bone healing at implants with a fluoridemodified surface: an experimental study in dogs. Clin Oral Impl Res 2007; 18: 147-152.

Bernhardt R, Dolder J van den, Bierbaum S, Beutner R, Scharnweber D, Jansen J, Beckmann $\mathrm{F}$, Worch $\mathrm{H}$. Osteoconductive modifications of Ti-implants in a goat defect model: characterization of bone growth with SR muCT and histology. Biomaterials 2005; 26 : 3009-3019.

Bollinger A, Partsch H. Christian Doppler is 200 years young. Vasa 2003; 32: 225-233.

Bornstein MM, Valderrama P, Jones AA, Wilson TG, Seibl R, Cochran DL. Bone apposition around two different sandblasted and acid-etched titanium implant surfaces: a histomorphometric study in canine mandibles. Clin Oral Impl Res 2008; 19: 233-241.

Brånemark PI, Adell R, Breine U, Hansson BO, Lindstrom J, Ohlsson A. Intra-osseous anchorage of dental prostheses. I. Experimental studies. Scand J Plast Reconstr Surg 1969; 3: 81-1002.

Brogniez V, D'Hoore W, Grégoire V, Munting E, Reychler H. Implants placed in an irradiated dog mandible: a morphometric analysis. Int J Oral Maxillofac Implants 2000; 15: 511518.2

Brook IM, Hatton PV. Glass-ionomers: bioactive implant materials. Biomaterials 1998; 19: 565-571.

Bumgardner JD, Chesnutt BM, Yuan Y, Yang Y, Appleford M, Oh S, McLaughlin R, Elder $\mathrm{SH}$, Ong JL.The integration of chitosan-coated titanium in bone: an in vivo study in rabbits. Implant Dent 2007; 16: 66-79. 
Buser D, Schenk RK, Steinemann S, Fiorellini JP, Fox CH, Stich H. Influence of surface characteristics on bone integration of titanium implants. A histomorphometric study in miniature pigs. J Biomed Mater Res 1991; 25: 889-902.

Carlsson L, Rostlund T, Albrektsson B, Albrektsson T. Removal torques for polished and rough titanium implants. Int J Oral Maxillofac Implants 1988; 3: 21-24.

Carlsson GE, Kronström M, de Baat C, Cune M, Davis D, Garefis P, Heo SJ, Jokstad A, Matsuura M, Närhi T, Ow R, Pissiotis A, Sato H, Zarb GA. A survey of the use of mandibular implant overdentures in 10 countries. Int J Prosthodont 2004; 17: 211-217.

Caulier $\mathrm{H}$. An animal experimental study to improve the success rate of oral implants in bone of low density: The influence of Ca-P coatings. Thesis. Nijmegen: Katholieke Universiteit Nijmegen, 1996.

Cawood JI, Stoelinga PJ. International Academy for Oral and Facial Rehabilitation - consensus report. Int J Oral Maxillofac Surg 2006; 35: 195-198.

Cawood JI, Stoelinga PJ, Blackburn TK. The evolution of preimplant surgery from preprosthetic surgery. Int J Oral Maxillofac Surg 2007; 36: 377-385.

Chang TL, Garrett N, Roumanas E, Beumer J ${ }^{\text {3rd }}$. Treatment satisfaction with facial prostheses. J Prosthet Dent 2005; 94: 275-280.

Colella G, Cannavale R, Pentenero M, Gandolfo S. Oral implants in radiated patients: A systematic review. Int J Oral Maxillofac Implants 2007; 22: 616-622.

Coulthard P, Esposito M, Worthington HV, Jokstad A. Therapeutic use of hyperbaric oxygen for irradiated dental implant patients: a systematic review. J Dent Educ 2003; 67: 64-68.

Davies JE. Mechanism of endosseous integration. Int J Prosthodont 1998; 11: 391-401.

De Bruijn JD, van den Brink I, Mendes S, Dekker R, Bovell YP, van Blitterswijk CA. Bone induction by implants coated with cultured osteogenic bone marrow cells. Adv Dent Res 1999; 13: 74-81.

DeLaney TF, Trofimov AV, Engelsman M, Suit HD. Advanced-technology radiation therapy in the management of bone and soft tissue sarcomas. Cancer Control 2005; 12: 27-35.

Denissen HW, Kalk W, Veldhuis AAH, van den Hooff A. Eleven-year study of hydroxyapatite implants. J Prosthet Dent 1989; 61: 706-712.

Devlin $\mathrm{H}$, Horner K, Ledgerton D. A comparison of maxillary and mandibular bone mineral densities. J Prosthet Dent 1998; 79: 323-327.

De Wijs FL, Van Dongen RC, De Lange GL, De Putter C. Front tooth replacement with Tubingen (Frialit) implants.2 J Oral Rehabil 1994; 21: 11-26.

Du C, Schneider GB, Zaharias R, Abbott C, Seabold D, Stanford C, Moradian-Oldak J. Apatite/amelogenin coating on titanium promotes osteogenic gene expression. J Dent Res 2005; 84: 1070-1074.

Dudziak ME, Saadeh PB, Mehrara BJ, Steinbrech DS, Greenwald JA, Gittes GK, Duyck J, Naert I. Failure of oral implants: aetiology, symptoms and influencing factors. Clin Oral Investig 1998; 2: 102-114.

Longmaker MT. The effects of ionizing radiation on osteoblast-like cells in vitro. Plast Reconstr Surg 2000; 106: 1049-1061.

Duwelius PJ, Schmidt AH. Assessment of bone viability in patients with osteomyelitis: preliminary clinical experience with laser Doppler flowmetry. J Orthop Trauma 1992; 6: 327-332.

Galli C, Guizzardi S, Passeri G, Martini D, Tinti A, Mauro G, Macaluso GM. Comparison of human mandibular osteoblasts grown on two commercially available titanium implant surfaces.2 J Periodontol 2005; 76: 364-372. 
Gbara A, Darwich K, Li L, Schmelzle R, Blake F. Long-term results of jaw reconstruction with microsurgical fibula grafts and dental implants. J Oral Maxillofac Surg 2007; 65: 1005-1009.

Gerlach NL, Barkhuysen R, Kaanders JHAM, Janssens GORJ, Sterk W. The effect of hyperbaric oxygen therapy on quality of life in oral and oropharyngeal cancer patients treated with radiotherapy. Int J Oral Maxillofac Surg 2008, 37: 255-259.

Glauser R, Zembic A, Ruhstaller P, Windisch S. Five-year results of implants with an oxidized surface placed predominantly in soft quality bone and subjected to immediate occlusal loading. J Prosthet Dent 2007; 97: S59-S68.

Grotz KA, Al-Nawas B, Piepkorn B, Reichert TE, Duschner H, Wagner W. Micromorphological findings in jaw bone after radiotherapy. Mund Kiefer Gesichtschir 1999; 3: 40-145.

Hayakawa T, Takahashi K, Yoshinari M, Okada H, Yamamoto H, Sato M, Nemoto K. 2Trabecular bone response to titanium implants with a thin carbonate-containing apatite coating applied using the molecular precursor method. Int $\mathrm{J}$ Oral Maxillofac Implants 2006; 21: 851-858.

Hellem S, Jacobsson LS, Nilsson GE, Lewis DH. Measurement of microvascular blood flow in cancellous bone using laser Doppler flowmetry and 133Xe-clearance. Int J Oral Surg 1983; 12: 165-177.

Honda MJ, Hatanaka T, Okazaki Y, Ueda M. Long-term results of osseointegrated implantretained facial prostheses: a 5-year retrospective study. Nagoya J Med Sci 2005; 67: 109-116.

Hooper SM, Westcott T, Evans PL, Bocca AP, Jagger DC. Implant-supported facial prostheses provided by a maxillofacial unit in a U.K. regional hospital: longevity and patient opinions. J Prosthodont 2005; 14: 32-38.

Hulshoff JEG. Osteocapacity of calcium phosphate coatings. Thesis. Nijmegen: Katholieke Universiteit Nijmegen, 1997.

Hutton JE, Heath MR, Chai JY, Harnett J, Jemt T, Johns RB, McKenna S, McNamara DC, van Steenberghe D, Taylor R, Watson RM, Herrmann I. Factors related to success and failure rates at 3-year follow-up in a multicenter study of overdentures supported by Brånemark implants. Int J Oral Maxillofac Implants 1995; 10: 33-42.

Huwiler MA, Pjetursson BE, Bosshardt DD, Salvi GE, Lang NP. Resonance frequency analysis in relation to jawbone characteristics and during early healing of implant installation. Clin Oral Implants Res 2007; 18: 275-280.

Jemt T, Lekholm U, Adell R. Osseointegrated implants in the treatment of partially edentulous patients: a preliminary study on 876 consecutively placed fixtures. Int $\mathrm{J}$ Oral Maxillofac Implants 1989; 4: 211-217.

Jereczek-Fossa BA, Zarowski A, Milani F, Orecchia R. Radiotherapy-induced ear toxicity. Cancer Treat Rev 2003; 29: 417-430.

Jokstad A, Braegger U, Brunski JB, Carr AB, Naert I, Wennerberg A. Quality of dental implants. Int J Prosthodont 2004; 17: 607-641.

Kanatas AN, Lowe D, Harrison J, Rogers SN. Survey of the use of hyperbaric oxygen by maxillofacial oncologists in the UK. Br J Oral Maxillofac Surg 2005; 43: 219-225.

Knabe $\mathrm{C}$, Howlett $\mathrm{CR}$, Klar F, Zreiqat $\mathrm{H}$. The effect of different titanium and hydroxyapatitecoated dental implant surfaces on phenotypic expression of human bone-derived cells. J Biomed Mater Res A 2004; 71: 98-107.

Lazzara RT, Testori T, Trisi P, Porter SS, Weinstein RL. A human histologic analysis of osseotite and machined surfaces using implants with 2 opposing surfaces. Int J Period Rest Dent 1999; 19: 117-129. 
LeGeros RZ, Craig RG. Strategies to affect bone remodeling: osteointegration. J Bone Miner Res 1993; 8(suppl. 2): S583-S596.

Limm AA, Karakla DW, Watkins DV. Osteoradionecrosis of the cervical vertebrae and occipital bone: a case report and brief review of the literature.2 Am J Otolaryngol 1999; 20 : 408-411.

Lindh C, Nilsson M, Klinge B, Petersson A. Quantitative computed tomography of trabecular bone in the mandible. Dentomaxillofac Radiol 1996; 25: 146-150.

Lindquist LW, Carlsson GE, Jemt T. A prospective 15-year follow-up study of mandibular prostheses supported by osseointegrated implants. Clinical results and marginal bone loss. Clin Oral Implants Res 1996; 7: 329-336.

Liu Y, de Groot K, Hunziker EB. Osteoinductive implants: the mise-en-scene for drugbearing biomimetic coatings. Ann Biomed Eng 2004; 32: 398-406.

Lorant JA, Roumanas E, Nishimura R, Beumer $\mathrm{J}^{\text {3rd }}$, Wagman LD. Restoration of oral function after maxillectomy with osseous integrated implant retained maxillary obturators. Am J Surg 1994; 168: 412-414.

Manders PJ, Wolke JG, Jansen JA. Bone response adjacent to calcium phosphate electrostatic spray deposition coated implants: an experimental study in goats. Clin Oral Implants Res 2006; 17: 548-553.

Markkanen-Leppanen M, Makitie AA, Haapanen ML, Suominen E, Asko-Seljavaara S. Quality of life after free-flap reconstruction in patients with oral and pharyngeal cancer. Head Neck 2006; 28: 210-216.

Marunick MT, Roumanas ED. Functional criteria for mandibular implant placement post resection and reconstruction for cancer. J Prosthet Dent 1999; 82: 107-113.

Marx RE. Osteoradionecrosis - A new concept of its pathophysiology. J Oral Maxillofac Surg 1983; 41: 283-288.

Meredith N, Alleyne D, Cawley P. Quantitative determination of the stability of the implanttissue interface using resonance frequency analysis. Clin Oral Implants Res 1996; 7: 261-267.

Meredith N, Shagaldi F, Alleyne D, Sennerby L, Cawley P. The application of resonance frequency measurements to study the stability of titanium implants during healing in the rabbit tibia. Clin Oral Implants Res 1997; 8: 234-243.

Merolli A, Bosetti M, Giannotta L, Lloyd AW, Denyer SP, Rhys-Williams W, Love WG, Gabbi C, Cacchioli A, Leali PT, Cannas M, Santin M. In vivo assessment of the osteointegrative potential of phosphatidylserine-based coatings. J Mater Sci Mater Med 22006; 17 : 789-794.

Michelson G, Schmauss B, Langhans MJ, Harazny J, Groh MJ. Principle, validity, and reliability of scanning laser Doppler flowmetry. J Glaucoma 1996; 5: 99-105.

Oates TW, Valderrama P, Bischof M, Nedir R, Jones A, Simpson J, Toutenburg H, Cochran DL. Enhanced implant stability with a chemically modified SLS surface: A randomized pilot study. Int J Oral Maxillofac Implants 2007; 22: 755-760.

Parliament M, Alidrisi M, Munroe M, Wolfaardt J, Scrimger R, Thompson H, Field C, Kurien $\mathrm{E}$, Hanson J. Implications of radiation dosimetry of the mandible in patients with carcinomas of the oral cavity and nasopharynx treated with intensity modulated radiation therapy. Int J Oral Maxillofac Surg 2005; 34: 114-121.

Pilliar RM. Overview of surface variability of metallic endosseous dental implants: tectured and porous surface-structured designs. Implant Dent 1998; 7: 305-314.

Puleo DA, Nanci A. Understanding and controlling the bone-implant interface. Biomaterials 1999; 20: 2311-2321. 
Quayle AA, Cawood J, Howell RA, Eldridge DJ, Smith GA. The immediate or delayed replacement of teeth by permucosal intra-osseous implants: the Tubingen implant system. Part 1. Implant design, rationale for use and pre-operative assessment. Br Dent J 1989; 20: 365-370.

Rabel A, Köhler SG, Schmidt-Westhausen AM. Clinical study on the primary stability of two dental implant systems with resonance frequency analysis. Clin Oral Investig 2007; 11: 257-265.

Rasmusson L, Roos J, Bystedt H. A 10-year follow-up study of titanium dioxide-blasted implants. Clin Implant Dent Relat Res 2005; 7: 36-42.

Rauch F, Schoenau E. Changes in bone density during childhood and adolescence: an approach based on bone's biological organization. J Bone Miner Res 2001; 16: 597604.

Roumanas ED, Freymiller EG, Chang TL, Aghaloo T, Beumer J 3rd. Implant-retained prostheses for facial defects: an up to 14-year follow-up report on the survival rates of implants at UCLA. Int J Prosthodont 2002; 15: 325-332.

Roumanas ED, Garrett N, Blackwell KE, Freymiller E, Abemayor E, Wong WK, Beumer J 3rd, Fueki K, Fueki W, Kapur KK. Masticatory and swallowing threshold performances with conventional and implant-supported prostheses after mandibular fibula free-flap reconstruction. J Prosthet Dent 2006; 96: 289-297.

Schepers RH, Slagter AP, Kaanders JH, van den Hoogen FJ, Merkx MA. Effect of postoperative radiotherapy on the functional result of implants placed during ablative surgery for oral cancer. Int J Oral Maxillofac Surg 2006; 35: 803-808.

Schliephake $\mathrm{H}$, Jamil MU. Prospective evaluation of quality of life after oncologic surgery for oral cancer.2 Int J Oral Maxillofac Surg2 2002; 31: 427-433.

Schoen PJ, Raghoebar GM, van Oort RP, Reintsema H, van der Laan BF, Burlage FR, Roodenburg JL, Vissink A.Treatment outcome of bone-anchored craniofacial prostheses after tumor surgery. Cancer 2001; 92: 3045-3050.

Schoen PJ, Reintsema H, Raghoebar GM, Vissink A, Roodenburg JL.The use of implant retained mandibular prostheses in the oral rehabilitation of head and neck cancer patients. A review and rationale for treatment planning. Oral Oncol 2004; 40: 862-871.

Schoen PJ, Raghoebar GM, Bouma J, Reintsema H, Vissink A, Sterk W, Roodenburg JL. Rehabilitation of oral function in head and neck cancer patients after radiotherapy with implant-retained dentures: Effects of hyperbaric oxygen therapy. Oral Oncol 2007; 43: 379-388.

Schliephake H, Aref A, Scharnweber D, Bierbaum S, Roessler S, Sewing A. Effect of immobilized bone morphogenic protein 2 coating of titanium implants on peri-implant bone formation. Clin Oral Implants Res 2005; 16: 563-569.

Schupbach P, Glauser R, Rocci A, Martignoni M, Sennerby L, Lundgren A, Gottlow J. The human bone-oxidized titanium implant interface: A light microscopic, scanning electron microscopic, back-scatter scanning electron microscopic, and energy-dispersive $\mathrm{x}$-ray study of clinically retrieved dental implants. Clin Implant Dent Relat Res 2005; 7(suppl. 1): S36-43.

Sennerby L, Persson LG, Berglundh T, Wennerberg A, Lindhe J. Implant stability during initiation and resolution of experimental periimplantitis: an experimental study in the dog. Clin Implant Dent Rel Res 2005; 7: 136-140.

Shahlaie M, Gantes B, Schulz E, Riggs M, Crigger M. Bone density assessments of dental implant sites: 1. Quantitative computed tomography. Int J Oral Maxillofac Implants 2003; 18: 224-231. 
Shaw RJ, D'Souza J, Kanatas AN, Rogers SN. The case for hyperbaric oxygen (HBO) in prevention and treatment of osteoradionecrosis (ORN) of the irradiated jaws. $\mathrm{Br} \mathrm{J}$ Oral Maxillofac Surg 2007; 45: e1.

Siebers MC. Electrostatic spray deposited calcium phosphate coatings: cyto- and histocompatibility. Thesis. Nijmegen: Radboud Universiteit, 2006.

Stadlinger B, Pilling E, Huhle M, Mai R, Bierbaum S, Scharnweber D, Kuhlisch E, Loukota $\mathrm{R}$, Eckelt U. Evaluation of osseointegration of dental implants coated with collagen, chondroitin sulphate and BMP-4: an animal study. Int J Oral Maxillofac Surg 2008; 37: 54-59.

Sul YT, Johansson CB, Jeong Y, Roser K, Wennerberg A, Albrektsson T. Oxidized implants and their influence on the bone response. J Mater Sci Mater Med 2001; 12: 1025-1031.

Sul YT, Johansson C, Wennerberg A, Cho LR, Chang BS, Albrektsson T. Optimum surface properties of oxidized implants for reinforcement of osseointegration: surface chemistry, oxide thickness, porosity, roughness, and crystal structure. Int J Oral Maxillofac Implants 2005; 20: 349-359.

Sul YT, Jeong Y, Johansson C, Albrektsson T. Oxidized, bioactive implants are rapidly and strongly integrated in bone. Part 1 - experimental implants. Clin Oral Implants Res 2006a; 17: 521-526.

Sul YT, Johansson C, Albrektsson T. Which surface properties enhance bone response to implants? Comparison of oxidized magnesium, TiUnite, and Osseotite implant surfaces. Int J Prosthodont 2006b; 19: 319-328.

Swiontkowski MF, Hagan K, Shack RB. Adjunctive use of laser Doppler flowmetry for debridement of osteomyelitis. J Orthop Trauma 1989; 3: 1-5.

Teoh KH, Huryn JM, Patel S, Halpern J, Tunick S, Wong HB, Zlotolow IM. Implant prosthodontic rehabilitation of fibula free-flap reconstructed mandibles: a Memorial SloanKettering Cancer Center review of prognostic factors and implant outcomes. Int J Oral Maxillofac Implants 2005; 20: 738-746.

Ter Brugge PJ. Tailor-made implant surfaces: the effects of surface roughness and calcium phosphate coating. Thesis. Nijmegen: Katholieke Universiteit Nijmegen, 2002.

The J. Applications of Doppler imaging in the musculoskeletal system. Curr Probl Diagn Radiol 2006; 35: 22-34.

Thomas KA, Kay JF, Cook SD, Jarcho M. The effect of surface macrotexture and hydroxylapatite coating on the mechanical strengths and histologic profiles of titanium implant materials. J Biomed Mater Res 1987; 21: 1395-1414.

Todisco M, Trisi P. Bone mineral density and bone histomorphometry are statistically related. Int J Oral Maxillofac Implants 2005; 20: 898-904.

Toljanic JA, Eckert SE, Roumanas E, Beumer J, Huryn JM, Zlotolow IM, Reisberg DJ, Habakuk SW, Wright RF, Rubenstein JE, Schneid TR, Mullasseril P, Garcia LT, Bedard JF, Choi YG. Osseointegrated craniofacial implants in the rehabilitation of orbital defects: an update of a retrospective experience in the United States. J Prosthet Dent 2005; 94: 177-182.

Traini T, Assenza B, San Roman F, Thams U, Caputi S, Piattelli A. Bone microvascular pattern around loaded dental implants in a canine model. Clin Oral Investig 2006; 10: 151-156.

Turkyilmaz I, Tumer C, Ozbek EN, Tözüm TF. Relations between the bony density values from computerized tomography, and implant stability parameters: a clinical study of 230 regular platform implants. J Clin Periodontol 2007; 34: 716-722. 
Van Cann E, Dom M, Koole R, Merkx MA, Stoelinga PJ. Health related quality of life after mandibular resection for oral and oropharyngeal squamous cell carcinoma. Oral Oncol 2005; 41: 687-693.

Vandamme K, Naert I, Vander Sloten J, Puers R, Duyck J. Effect of implant surface roughness and loading on peri-implant bone formation. J Periodontol 2008; 79: 150-157.

Van den Beucken JJJP. DNA-based coatings in implantology. Utilization of the structural properties of the DNA-molecule to modulate cell and tissue response. Nijmegen: Radboud Universiteit, 2007.

Van Dijk K. RF magnetron sputter deposition and characterization of $\mathrm{Ca}_{5}\left(\mathrm{PO}_{4}\right)_{3} \mathrm{OH}-$ coatings. Thesis. Nijmegen: Katholieke Universiteit Nijmegen, 1997.

Vercaigne $\mathrm{S}$. The influence of implant surface characteristics on bone response. Thesis. Nijmegen: Katholieke Universiteit Nijmegen, 1999.

Visch LL, van Waas MAJ, Schmitz PI, Levendag PC. A clinical evaluation of implants in irradiated oral cancer patients. J Dent Res 2002; 81: 856-859.

Von Arx T, Chappuis V, Winzap-Kälin C, Bornstein MM. Laser Doppler flowmetry for assessment of anterior mandibular teeth in conjunction with bone harvesting in the symphysis: A clinical pilot study. Int J Oral Maxillofac Implants 2007; 22: 383-389.

Walboomers F. Engineered implant surfaces. Modification of cell and tissue response by microgrooves. Thesis. Nijmegen: Katholieke Universiteit Nijmegen, 2000.

Wataha JC. Materials for endosseous dental implants. J Oral Rehabil 1996; 23: 79-90.

Williams HJ, Davies AM. The effect of X-rays on bone: a pictorial review. Eur Radiol 2006; 16: 619-633.

Weinlaender M, Beumer J ${ }^{\text {rd }}$, Kenney FB, Lekovic V, Holmes R, Moy PK,Plenk H Jr. Histomorphometric and fluorescence microscopic evaluation of interfacial bone healing around 3 different dental implants before and after radiation therapy. Int $\mathrm{J}$ Oral Maxillofac Implants 2006; 21: 212-224.

Wenz HJ, Bartsch J, Wolfart S, Kern M. Osseointegration and clinical success of zirconia dental implants: A systematic review. Int J Prosthodont 2008; 21: 27-36.

Wong K. Laser Doppler flowmetry for clinical detection of blood flow as a measure of vitality in sinus bone grafts. Implant Dent 2000; 9: 133-142.

Xie XT, Qu WL, Yuan WH, Wang ZH. Experimental study of radiation effect on the mandibular microvasculature of the guinea pig. Chin J Dent Res 1998; 1: 46-51.

Yonggang Y. RF magnetron sputtered pyrophosphate coatings: Physicochemical and biological characteristics. Thesis. Nijmegen: Radboud Universiteit, 2006.

Zarem HA, Carr R. Salvage of the exposed irradiated mandible. Plast Reconstr Surg 1983; 72: 648-655. 



\section{CHAPTER 2}

\section{Assessment of vascularity in irradiated and} nonirradiated maxillary and mandibular minipig alveolar bone using laser Doppler flowmetry

Int J Oral Maxillofac Implants 2007; 22: 774-778.
H.W.D. Verdonck
G.J. Meijer
T. Laurin
F.H. Nieman
C. Stoll
D. Riediger
P.J.W. Stoelinga
C. de Baat 


\subsection{Introduction}

Current data suggest that osseointegration is impaired in irradiated bone. ${ }^{1,2}$ Implant survival rates are known to be lower in irradiated bone than in nonirradiated bone, particularly if the irradiation dose exceeds 50 $\mathrm{Gy}^{3-6}$ Prospective studies have shown that irradiated bone becomes hypocellular and hypoxic and that the vascularity of irradiated bone decreases over time. ${ }^{7}$ As a result, the continuous bone remodeling capacity diminishes, which explains the lower implant survival rates.

In irradiated patients, a method for assessment of vascularity of intended implant recipient sites would be of great significance in preventing early implant loss. Laser Doppler flowmetry (LDF) could be an appropriate method. Modern LDF techniques use a laser diode device to produce a beam of near-infrared laser light with an operating wavelength of 780 to $820 \mathrm{~nm}$, which is beamed into human tissues by a fiber optic connector. ${ }^{8,9}$ The photons are scattered, and light hitting moving blood cells undergoes a change in wavelength (Doppler shift), while the wavelength of the light hitting static structures is unchanged. A returning fiber in the probe picks up and carries the light back to a photo detector. The magnitude of the signal and the frequency changes is directly related to the relative number and velocity of blood cells in a recorded volume.

Wong introduced the concept of LDF as a diagnostic tool for verification of bone graft vitality following a maxillary sinus grafting procedure. Six months after the grafting procedure, detection of blood flow in all graft sites indicated successful angiogenesis. ${ }^{10}$ In a previous study, LDF was used for recording microvascular blood flow in cancellous mandibular bone of young pigs. ${ }^{11}$ LDF has also been shown to be useful for the assessment of bone vitality in osteomyelitis and in many other applications. ${ }^{12-14}$

The hypotheses of this study were that less vascularity would be found in irradiated maxillary and mandibular alveolar bone compared to nonirradiated bone and that LDF is a reproducible method for the assessment of alveolar bone vascularity.

\subsection{Materials and methods}

Six 1-year-old adult Göttingen minipigs were used for this study. The experiments were conducted in accordance with German and European 
Community guidelines on the protection of laboratory animals. Permission was obtained from the Animal Ethical Committee of the University of Aachen.

All maxillary and mandibular premolars and molars of the minipigs were extracted under general anesthesia induced by isoflurane $0.8 \%$ to $1.1 \%$. Interoperatively, and for 3 days postoperatively, clindamycin was administered as an antimicrobial agent. After a 3-month alveolar bone healing period, the maxillary and mandibular bone of 3 minipigs received bilaterally 3 irradiation (cobalt) exposures up to $8 \mathrm{~Gy}$, with 7-day intervals between exposures, for a total dose of $24 \mathrm{~Gy}$. Each radiation field (left and right) contained half the mandible as well as half the maxilla; thus, the irradiation was evenly distributed among the arches and jaws. At 3 months after irradiation, computed tomographic (CT) scans were performed under general anesthesia. The data from these scans were used for generating stereolithographic 3D models. Subsequently, the data were imported into a software program Simplant; Materialise, Leuven, Belgium) for preoperative planning of implant positions at the edentulous maxillary and mandibular sites in a virtual environment and for the design of accurate customized surgical templates, which were made by rapid prototyping for transfer of the planned implant positions to the minipigs. Surgical treatment of the maxillary and mandibular edentulous sites was begun with an incision on top of the alveolar crest and a release incision that sloped buccally and anteriorly. Subsequently, the periosteum was reflected gently, exposing the underlying alveolar bone. To avoid interference with the local blood flow, no anesthetic agent was administered by local infiltration. Using a customized surgical template and a pilot drill of the implant system used (Biocomp, Vught, The Netherlands), 5 initial holes were drilled in the residual alveolar ridge of each edentulous site (20 holes in each minipig). LDF recordings were carried out, and the initial holes were further widened for implant insertion. Implant placement was carried out as part of an ongoing study on the effects of irradiation on implant stability and implant survival. A total of 120 nonsubmerged Biocomp implants, $3.4 \mathrm{~mm}$ in diameter and $10 \mathrm{~mm}$ in length, were placed in the 6 minipigs. In 1 irradiated and 1 nonirradiated minipig, an additional hole was drilled in the right edentulous maxillary site to be able to perform repeated LDF recordings for determining the recording error and for validating the standardization of recordings.

Local microvascular blood flow in the surrounding alveolar bone of all 120 initial holes was recorded by LDF at a fixed depth of $6 \mathrm{~mm}$, according 
to the protocol used by Wong. ${ }^{10}$ The emitted laser light $(780 \mathrm{~nm})$ was transduced to the recording site by a special side-reading optical fiber probe with a diameter of $2.8 \mathrm{~mm}$ (Fig 1; PF 415-254; Periflux System, Perimed, Sweden). Before installation of the probe, the initial hole was rinsed with a saline solution to avoid contamination. The minipig was optimally stabilized during the recording to avoid disturbing movements. Disturbing movements of the pig, if any, were promptly apparent in the recording graphic. Within a few seconds after installation of the probe, the graphic stabilized and remained stable during the recording period. A 20second noise-free period appeared sufficient for a stable and reliable recording session. In every initial hole 4 recordings were carried out with the probe perpendicularly directed to the mesial, buccal, distal, and palatal or lingual hole wall successively (Fig 2).To test the reproducibility of recordings, in the additional right maxillary hole in 1 irradiated and 1 nonirradiated minipig, 10 similar recordings were carried out, providing 40 recordings per hole.

The LDF module was connected to a personal computer for calculating the recordings. The magnitude of the signal and frequency changes was directly related to the relative number and velocity of the blood cells in the recorded volume. ${ }^{15}$ The recordings in the 4 directions were averaged, revealing the average blood flow per hole, expressed in perfusion units (PU). Although PU is an arbitrary unit, a linear relationship between $\mathrm{PU}$ and blood flow expressed in $\mathrm{mL} / \mathrm{min} / 100 \mathrm{~g}$ has been demonstrated. ${ }^{15}$

Local microvascular blood flow recordings were tested for normality of distribution by the Kolmogorov-Smirnov test.

Data analysis was first performed on the 80 recordings of the additional maxillary hole in 1 irradiated and 1 nonirradiated minipig. The recording error or reproducibility of local microvascular blood flow recordings was estimated by variance components analysis using multifactor repeated-measures analysis of variance (ANOVA)."Minipigs" (P) and "recordings" (R) were considered random factors, with 2 (irradiated and nonirradiated) and 10 categories (10 recordings in 1 direction), respectively. "Direction" (D) was the fixed factor with 4 categories. A mean-direction intraclass correlation coefficient (ICC) for 1 direction was calculated from the ratio of the total of the estimated variance components of $P$ and of $P x$ $D$ divided by the sum of estimated coefficients of $P, P \times D, P \times R$, and $P x$ $\mathrm{R} \times \mathrm{D}$. Beforehand, it was decided that the ICC should be at least 0.90 for sufficiently reproducible microvascular blood flow recordings. 


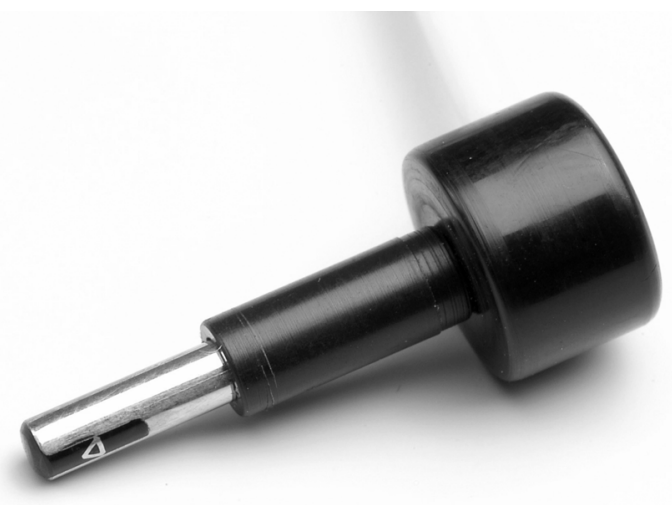

Figure 1. Side-reading LDF probe.

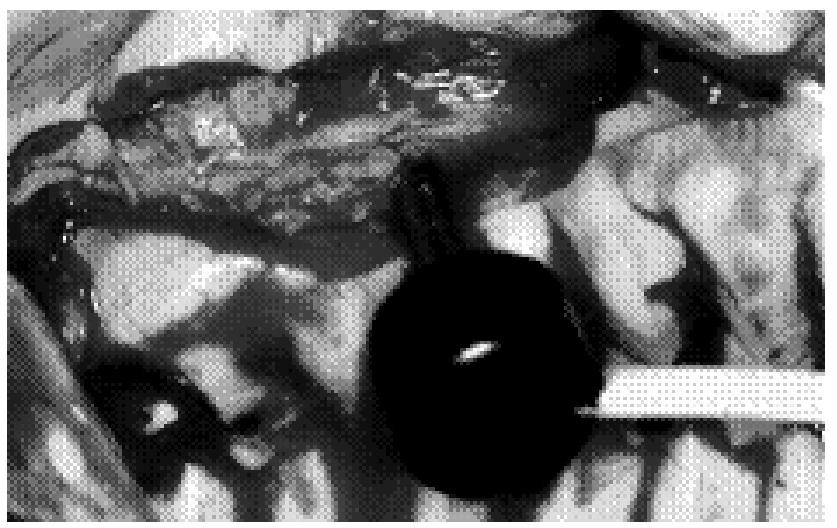

Figure 2. LDF probe placed in an initial hole drilled in the maxilla.

Separate similar analyses by repeated-measures ANOVA were performed to estimate the reproducibility of recordings in each of the 4 recording directions.

Subsequently, data analysis was performed on the recordings in the 120 initial implant holes, to determine the irradiation effect on bone vascularity. Fixed between-factor in the analysis was irradiation with 2 categories (yes-no) and fixed within-factors were jaw (maxillary-mandibular), side (left-right) and within jaw implant position (1 to 5).If associations were statistically significant, an analysis was carried out using repeated- 
measures ANOVA or a Student $t$ test on partial data. $P=.05$ was determined as the level of significance for all comparisons. Reproducibility data were analyzed by the GENOVA program of Crick \& Brennan. Irradiation effect data were analyzed by SPSS version 12.0 (SPSS, Chicago, IL).

\subsection{Results}

The normality of the distribution of the recordings of microvascular blood flow was at an acceptable level (Kolmogorov-Smirnov test; $P=.051$ ). The data of the 80 recordings of the additional maxillary holes are presented in Table 1.

The 10 recordings in each direction were consistent, but there were distinct differences between the recordings for the 4 directions in each hole. In irradiated alveolar bone the recordings were consistently lower compared to the recordings in nonirradiated alveolar bone.

The overall ICC was 0.944 . Separate analyses for the 4 different directions revealed ICCs of 0.981 (mesial), 0.978 (buccal), 0.894 (distal), and 0.878 (palatal). The overall $F$ ratio for irradiation was 22.43 by 1 and $4 \mathrm{df}(P=.009)$. The association between jaw, side, and irradiation was statistically significant ( $F=23.80$ by 1 and $4 \mathrm{df} ; P=.008)$. Irradiation had a maximal effect in the left part of the mandible $(\mathrm{t}=7.47 ; P=.002$; overall mandible, $\mathrm{t}=10.62 ; P<.001$; overall maxilla, $\mathrm{t}=2.52 ; P=.065)$. The rradiation effect was statistically significant at the maxillary left side $(\mathrm{t}=$ 5.96, $P=.004)$, but not at the maxillary right side $(t=1.85, P=.139)$. Table 2 lists means and standard deviations of alveolar bone vascularity of the 6 minipigs. 
Table 1 Recordings $(n=80)$ in the additional Maxillary Holes in an Irradiated and a Nonirradiated Minipig

\begin{tabular}{lllllllll}
\hline & \multicolumn{1}{l}{ Irradiated } & \multicolumn{7}{l}{ Nonirradiated } \\
\hline recording no. & $\mathrm{M}$ & $\mathrm{B}$ & $\mathrm{D}$ & $\mathrm{P}$ & $\mathrm{M}$ & $\mathrm{B}$ & $\mathrm{D}$ & $\mathrm{P}$ \\
1 & 12.84 & 4.51 & 9.23 & 19.47 & 28.85 & 13.74 & 12.21 & 34.63 \\
2 & 11.38 & 4.43 & 8.30 & 18.01 & 30.44 & 14.44 & 9.01 & 34.83 \\
3 & 11.16 & 4.89 & 8.47 & 17.61 & 33.69 & 12.05 & 10.99 & 27.82 \\
4 & 13.67 & 4.55 & 8.89 & 22.29 & 33.94 & 15.39 & 11.34 & 28.78 \\
5 & 12.29 & 4.16 & 8.31 & 19.97 & 29.57 & 13.85 & 10.85 & 25.66 \\
6 & 13.48 & 4.26 & 7.85 & 18.17 & 28.09 & 15.01 & 11.09 & 25.23 \\
7 & 13.84 & 4.31 & 8.49 & 18.07 & 31.94 & 11.58 & 12.27 & 34.11 \\
8 & 11.23 & 4.23 & 9.28 & 17.77 & 28.24 & 15.47 & 12.50 & 32.29 \\
9 & 11.35 & 4.66 & 8.25 & 17.61 & 25.93 & 15.63 & 11.85 & 29.12 \\
10 & 11.87 & 3.99 & 8.42 & 17.46 & 28.61 & 14.39 & 12.86 & 26.64 \\
Mean recording & 12.31 & 4.40 & 8.55 & 18.64 & 29.93 & 14.16 & 11.49 & 29.91 \\
\hline
\end{tabular}

The probe was perpendiculary directed to the mesial, buccal, distal and palatal walls of the hole. $\mathrm{M}=$ mesial, $\mathrm{B}=$ buccal, $\mathrm{D}=$ distal, $\mathrm{P}=$ palatal

Table 2 Means an SDs of Alveolar Bone Vascularity of the 6 Minipigs

\begin{tabular}{lrr}
\hline Jaw/side/irradiation & Mean & SD \\
\hline Maxilla & & \\
Right & & \\
$\quad$ No & 22.136 & 10.475 \\
Yes & 9.762 & 4.998 \\
Left & & \\
$\quad$ No & 16.085 & 1.938 \\
$\quad$ Yes & 9.221 & 0.468 \\
Mandible & & \\
Right & & \\
No & 15.147 & 4.130 \\
Yes & 5.392 & 3.263 \\
Left & & \\
No & 17.755 & 3.128 \\
Yes & 3.544 & 1.030 \\
\hline
\end{tabular}

\subsection{Discussion}

The results presented in this study suggest that LDF can be used for the assessment of alveolar bone vascularity in pilot holes before implant placement. However, recordings varied by edentulous site as well as by minipig. In order to be useful in human beings, normal values of alveolar bone vascularity of the various alveolar sites of both the maxilla and mandible should be determined. These values may vary not only from person to person but also depending on the individual amount of local 
residual alveolar bone. Therefore, further research validating the use of LDF in human beings, especially in those who have undergone radiation therapy for head and neck cancer, is necessary. Standardization of instrument and measuring method is required for comparing results between different laser Doppler users. Probes and equipment parameters must be consistent, and the instrument must be calibrated according to the manufacturer's instructions.

The variations in recordings for the 4 different directions were presumably caused by the nonhomogeneous calcified and trabecular alveolar bone structure around the holes. As a consequence, recordings in different directions are needed for determining the average alveolar bone vascularity around 1 hole. The 10 recordings in the additional right maxillary holes provided consistent values. Consequently, in future research projects, using 1 recording in each of the 4 directions will be suitable. The overall ICC was 0.944 ; thus, the reproducibility of the recordings was sufficient.

In general, in irradiated patients at least a 6-month interval is recommended between tooth extraction and implant placement to allow for bone healing. ${ }^{16}$ In this study, a similar interval was used: a 3-month interval between extractions and radiation therapy and another 3-month interval until implant placement. Three months after irradiation, the edentulous alveolar bone appeared less vascularized in irradiated than in nonirradiated minipigs. Whether this observation can be transferred to human beings needs to be demonstrated, but the results of this study are in accordance with the results of previous studies. ${ }^{17,18}$

Three minipigs received 3 irradiation (cobalt) exposures up to $8 \mathrm{~Gy}$ with 7-day intervals, for a total dose of $24 \mathrm{~Gy}$ administered to the bone. Using an $\alpha / \beta$ ratio of 2.5 , this dose is biologically equivalent to approximately 56 Gy given in 28 fractions of 2 Gy each. A better research design would have been the split-mouth design: unilateral irradiation in all minipigs. An advantage of this method would have been reduction of the variability between the minipigs. Furthermore, each minipig would have been serving as his own control. However, unilateral irradiation of the maxilla and the mandible without any exposure of the contralateral side is not practical technically.

A distinct difference in blood perfusion (LDF recordings) was seen not only between irradiated and nonirradiated bone but also between maxillary and mandibular alveolar bone (Table 2). The effect of irradiation was more pronounced in the mandible than in the maxilla. This phenomenon 
was in accordance with the authors' expectations because the spongious maxillary bone is known to be better vascularized compared with the more dense mandibular bone.

Irradiation has a significant negative effect on bone vascularity, which has important clinical implications. Since reduced bone vascularity impairs oral implant osseointegration in patients who have undergone head and/or neck radiotherapy, recording bone vascularity prior to implant placement could be of significance in the decision-making process while preparing a treatment plan for prosthetic reconstructive therapy.

In this animal study, LDF was demonstrated to be a reproducible method for the assessment of alveolar bone vascularity. Hence, it may be used clinically to increase the predictability of implant treatments and even decrease the risk of osteoradionecrosis by avoiding implant insertion in poorly vascularized bone. Research is needed to determine whether LDF could be used to determine a minimum level of vascularity necessary to facilitate reliable implant placement. Another area for future research with LDF is the use of hyperbaric oxygen therapy in cases of osteoradionecrosis; the effectiveness of this therapy, which is based on increasing the bone vascularity, may also be demonstrated by LDF. The authors' future research will focus on determining a human standard of bone vascularity in the nonirradiated maxilla and mandible using LDF.

\subsection{Conclusion}

The hypothesis that less vascularity would be observed in irradiated maxillary and mandibular alveolar bone compared to nonirradiated bone was confirmed. Furthermore, it was confirmed that LDF is a reproducible method for the assessment of bone vascularity. 


\section{References}

1. Cawood JI, Stoelinga PJW. International Academy for Oral and Facial Rehabilitation Consensus Report. Int J Oral Maxillofac Surg 2006;35:195-198.

2. Weinlaender M, Beumer J III, Kenney EB, et al. Histomorphometric and fluorescence microscopic evaluation of interfacial bone healing around 3 different dental implants before and after radiation therapy. Int J Oral Maxillofac Implants 2006;21:212-224.

3. Granström G,Tjellström A, Brånemark P-I. Osseointegrated implants in irradiated bone: A case-controlled study using adjunctive hyperbaric oxygen therapy. J Oral Maxillofac Surg 1999;57:493-499.

4. Visch LL,Van Waas MAJ, Schmitz PIM, Levendag PC. A clinical evaluation of implants in irradiated oral cancer patients. J Dent Res 2002;81: 856-859.

5. Yerit KG, Posch M, Seemann M, et al. Implant survival in mandibles of irradiated oral cancer patients.Clin Oral Implants Res 2006;17:337-344.

6. Granström G. Osseointegration in irradiated cancer patients: An analysis with respect to implant failures. J Oral Maxillofac Surg 2005;63:579-585.

7. Marx RE. Osteoradionecrosis: A new concept of its pathophysiology. J Oral Maxillofac Surg 1983;41:283-288.

8. Bollinger A, Partsch H. Christian Doppler is 200 years young. Vasa 2003;32:225-233.

9. Michelson G, Schmauss B, Langhans MJ, Harazny J, Groh MJ. Principle, validity, and reliability of scanning laser Doppler flowmetry. J Glaucoma 1996;5:99-105.

10. Wong K. Laser Doppler flowmetry for clinical detection of blood flow as a measure of vitality in sinus bone grafts. Implant Dent 2000;9:133-142.

11. Hellem S, Jacobsson LS, Nilsson GE, Lewis DH. Measurement of microvascular blood flow in cancellous bone using laser Doppler flowmetry and 133Xe-clearance. Int J Oral Surg 1983;12:165-177.

12. Swiontkowski MF, Hagan K, Shack RB.Adjunctive use of laser Doppler flowmetry for debridement of osteomyelitis. J Orthop Trauma 1989;3:1-5.

13. Duwelius PJ, Schmidt AH.Assessment of bone viability in patients with osteomyelitis: Preliminary clinical experience with laser Doppler flowmetry. J Orthop Trauma 1992;6:327-332.

14. Teh J. Applications of Doppler imaging in the musculoskeletal system. Curr Probl Diagn Radiol 2006;35:22-34.

15. Ahn H, Johansson K, Lundgren O, Nilsson GE. In vivo evaluation of signal processors for laser Doppler tissue flowmeters. Med Biol Eng Comput 1987;25:207-211.

16. Harrison JS, Strateman S, Redding SW. Dental implants for patients who have had radiation treatment for head and neck cancer. Spec Care Dentist 2003;23:223-229.

17. Marx RE, Johnson RP. Studies in the radiobiology of osteoradionecrosis and their clinical significance. Oral Surg Oral Med Oral Pathol 1987;64:379-390.

18. Dudziak ME, Saadeh PB, Mehrara BJ, et al.The effects of ionizing radiation on osteoblast-like cells in vitro. Plast Reconstr Surg 2000;106:1049-1061. 


\section{CHAPTER 3}

\section{Implant stability during osseointegration in irradiated and non-irradiated minipig alveolar bone: An experimental study}

Clin Oral Implants Res 2008; 19: 201-206.
H.W.D. Verdonck
G.J. Meijer
T. Laurin
F.H. Nieman
C. Stoll
D. Riediger
P.J.W. Stoelinga
C. de Baat 


\subsection{Introduction}

Threaded and cylindrical endosseous titanium implants are commonly used in craniofacial and oral surgery (Lindquist et al.1996; Carlsson et al. 2004; Albrektsson \& Wennerberg 2005). Implants are placed in both nonirradiated and irradiated bone (Granström 2005). Achievement and maintenance of implant stability are prerequisites for long-term positive results. Stability is defined as the stiffness of an implant placed in bone (Meredith et al.1996). Primary implant stability, at insertion, is a mechanical phenomenon, which is related to local bone density. After insertion of an implant, implant stability is subject to changes due to bone remodeling. If primary implant stability is poor, the final result will be more dependent on osseointegration, which is subsequently related to bone vitality (Meredith 1998). After osseointegration, mechanically stable implants may be loaded. In general, a 3-6-month undisturbed implant healing phase is accepted as a prerequisite for achieving bone apposition without interposition of fibrous scar tissue (Brånemark et al. 1977). However, based on experimental research, there is a current tendency towards early or even immediate functional loading of implants (Szmukler-Moncler et al. 1998; Attard et al. 2005).

An inflammatory reaction on plaque accumulation induces bone loss around implants and reduced implant stability. Occlusal overload increases the risk for microfractures at the implant-bone interface, resulting in significant marginal bone loss, reduced implant stability, and even implant failure (Van Steenberghe et al.1999). In patients who have been treated for cancer in the head and neck region and who have undergone radiotherapy, implant stability is often impaired because irradiation reduces bone vitality (Grotz et al.1999). In order to improve tissue oxygenation and bone vascularity following radiotherapy, hyperbaric oxygen $(\mathrm{HbO})$ therapy may be used (Chavez \& Adkinson 2001).

Until recently, reliable and reproducible standardized methods measuring implant stability were not available in the scientific literature. Commonly used methods, such as percussion and Periotest, are not reliable (Faulkner et al. 2001). Radiographs are of certain significance, but a standardized technique ensuring reproducibility is needed. A reliable and validated method is resonance frequency analysis (RFA). The method quantitatively and objectively measures stability by application of microscopic flexural stress. RFA values are converted into an index known as an implant stability quotient (ISQ). Using RFA, the response of a small 
transducer attached to an implant fixture or abutment is recorded (Meredith et al. 1997). Differences in implant stability can be recorded in vivo at insertion of an implant and during the course of osseointegration. Changes in ISQ are related to alterations of implant stiffness in the surrounding tissues (Meredith et al. 1997). ISQ values can be used for determining different healing phases and the stability of the implants (Ersanli et al. 2005). Theoretically, ISQ values may range from 0 to 100. Successfully integrated implants have ISQ values above 40 (Balleri et al. 2002; Olsson et al. 2003; Farzad et al. 2004; Gallucci et al. 2004; Becker et al. 2005; Ostman et al. 2005; Vanden Bogaerde et al. 2005; Zix et al. 2005). The method may be used as a deciding factor determining the appropriate time of implant loading individually, because during osseointegration the maximum stability can be assessed. RFA usually shows a decrease of implant stability in the first month after implant placement, followed by an increase during the second and third months, suggesting an adaptive bone remodeling process around the implant (Balshi et al. 2005). RFA on implants inserted into the maxillae of minipigs showed that implant stability decreased after 1-3 months of healing. The implant stability increased after a healing period of 4 months (Nkenke et al. 2005). It has been suggested that RFA is sensitive and may be used for detecting even minor changes in the level of bone-implant contact (Sennerby et al. 2005).

The current randomized-controlled trial was designed to monitor and test implant stability immediately after implant placement and during osseointegration in irradiated and non-irradiated minipig alveolar bone. The hypothesis was that there are no differences in primary implant stability between irradiated and non-irradiated minipigs, but that during osseointegration implant stability is decreasing in a more pronounced manner in the irradiated minipigs, when compared with the non-irradiated minipigs because of impaired alveolar bone vascularity in the irradiated minipigs.

\subsection{Material and methods}

Six adult, 1-year-old Göttingen minipigs were used for this study. The experiments were conducted in accordance with German and European Community guidelines on the protection of (laboratory) animals. Permission was obtained from the Animal Ethical Committee of the University of Aachen. 
All maxillary and mandibular premolars and molars of the six minipigs were extracted under general anesthesia, induced by Isoflorane 0.8$1.1 \%$. Inter- and postoperatively for 3 days, clindamycine prophylaxis was administered as an antimicrobial agent. After a 3-month alveolar bonehealing period, the maxilla and mandible of three minipigs received three irradiation (Cobalt) exposures up to 8 Gray (Gy) with 7-day intervals at a total dose of 24Gy. At 3 months after irradiation, computed tomography (CT) scans were performed under general anesthesia. The data from these scans were used for generating stereolithographic 3D models. Subsequently, the data were also imported into a software program (Simplant, Materialise N.V., Leuven, Belgium) for planning implant positions preoperatively at the edentulous maxillary and mandibular sites in a virtual environment and for designing accurate customized surgical templates, made by rapid prototyping for transferring the planned implant positions to the minipigs.

Surgical treatment of the maxillary and mandibular edentulous sites was begun by an incision on top of the alveolar crest and a release incision, anteriorly sloping into the buccal vestibule. Subsequently, the periosteum was reflected gently, exposing the underlying alveolar bone. In order not to interfere with the local blood flow, no anesthetic agent was administered by local infiltration. Using the customized surgical template and a pilot drill of the implant system used (Biocomp, Vught, the Netherlands), five initial holes were drilled in the residual alveolar ridge of each edentulous site, in total, 20 holes in each minipig. In order to assess bone vascularity, laser Doppler flowmetry (LDF) recordings were carried out in the initial holes that, subsequently, were further widened for implant insertion (Verdonck et al. 2007). A total of 120 non-submerged Biocomp implants, diameter $3.4 \mathrm{~mm}$ and length $10 \mathrm{~mm}$, were placed in the six minipigs. Subsequently, primary implant stability was recorded by RFA using the Osstell instrument (Integration Diagnostics AB, Gothenburg, Sweden). Implant stability recordings were repeated at 8,16 , and 24 weeks after implant placement.

According to a power analysis for irradiated as well as non-irradiated minipigs, three animals were needed in each group to ascertain a statistically significant irradiation effect during the 24-week follow-up. Seventy percent reduction of implant stability was expected as an irradiation effect, using a power of $80 \%$ and a type I error of 0.05 .

Immediate postoperative implant stability recordings were tested for normality of distribution using the Kolmogorov- Smirnov test (K-S test). 
Because three of the 120 planned implant stability recordings were missing, an imputation rule was applied substituting ISQ values either by the average value of neighbouring implant sites, or - if the missing value happened to be located at the end of a row of five initial holes in an edentulous maxillary or mandibular site - by the ISQ value of the corresponding initial hole at the adjacent maxillary or mandibular edentulous site. The imputation rule was also applied for three missing values in baseline bone vascularity recordings. All missing ISQ values of lost implants during the 24-week follow-up were substituted by the empirically assumed lowest possible value (i.e. 30 ).

Firstly, primary implant stability at all 20 edentulous sites in irradiated as well as non-irradiated minipigs was analyzed with irradiation as a factor, using the Student t-test and the Mann-Whitney test. Subsequently, the ISQ values at the four recording times were compared by repeated measures ANOVA, using orthogonal polynomial contrasts for the 'time' within-factor and 'irradiation' as a between-factor.

Adjusting deviations from sphericity within the variance-covariance matrix of repeated measurements, Mauchly's test was used and degrees of freedom were corrected by Greenhouse-Geisser epsilons ascertaining a more conservative testing. Finally, the ISQ values of the four recording times were compared by repeated measures ANCOVA, using primary implant stability and bone vascularity as possible confounding covariates. The results of ANCOVA were converted into a dummy regression model quantifying the (corrected) effect of irradiation on the linear decrease of implant stability. If possible, interactions between 'time', experimental factor, and covariates were tested for statistical significance.

A P-value of 0.05 was set as the level of significance for all comparisons. All data were analyzed by SPSS-pc, version 12.0.

\subsection{Results}

During the first 8 weeks, 22 implants in mandibular edentulous sites of irradiated minipigs were lost and nine implants in mandibular edentulous sites of non-irradiated minipigs. In the edentulous maxillary sites, $14 \mathrm{im}-$ plants were lost in irradiated and 6 in non-irradiated minipigs. At 16 weeks after implant placement, one more implant was lost.

The normality of distribution of primary implant stability recordings was statistically significant, because two very low outlier ISQ values were 
present in one irradiated minipig $(\mathrm{K}-\mathrm{S}$ test; $\mathrm{P}<0.001)$. Upon removal of the outlier ISQ values, the $\mathrm{K}-\mathrm{S} \mathrm{P}$-value was 0.16 . Table 1 shows the mean ISQ values, standard deviations, medians, and ranges at all 20 edentulous implant sites of irradiated as well as nonirradiated minipigs of the recordings immediately after implant placement and at 8,16 , and 24 weeks after implant placement.

Table 1. Mean implant stability quotient (ISQ) values, standard deviations, medians, and ranges at all 20 edentulous implant sites of irradiated as well as non-irradiated minipigs of the recordings immediately after implant placement (primary) and at 8, 16, and 24 weeks after implant placement

\begin{tabular}{lllll}
\hline Minipigs & Primary & 8 weeks & 16 weeks & 24 weeks \\
\hline Non-irradiated & & & & \\
Mean & 74.5 & 56.2 & 53.3 & 54.7 \\
Standard deviation & 2.5 & 2.2 & 1.7 & 1.7 \\
Median & 73.4 & 57.3 & 54.2 & 54.6 \\
Range & $72.9-77.3$ & $53.7-57.8$ & $51.4-54.4$ & $53.1-56.4$ \\
Irradiated & & & & \\
Mean & 73.5 & 41.6 & 41 & 41.3 \\
Standard deviation & 4.5 & 7.9 & 7.3 & 7.9 \\
Median & 72.3 & 45.5 & 44.3 & 45 \\
Range & $69.7-78.4$ & $32.5-46.8$ & $32.7-46.2$ & $32.3-46.6$ \\
\hline
\end{tabular}

ISQ values of the recordings immediately after implant placement showed no statistically significant differences between irradiated and nonirradiated minipigs, analyzed either by the Student t-test $(P=0.74)$ or by the Mann-Whitney test $(P=0.70)$. Repeated measures ANOVA of the $I S Q$ values at the 4 recording times showed a statistically significant decrease of ISQ values in all minipigs ( $F=53.1$ by 1 and $4.1 \mathrm{df} ; P=0.002)$. However, the decrease was not statistically significant in the separate groups of irradiated and non-irradiated minipigs $(F=3.08$ by 1 and $4.1 \mathrm{df}$; $P=0.153)$. Both P-values were corrected by Greenhouse-Geisser epsilons. P-values of the linear component in the orthogonal polynomial contrasts were 0.002 for the overall irradiation effect and 0.174 for the differential group effect. The Mann-Whitney test on the difference between ISQ values immediately after implant placement and at 24 weeks after implant placement also revealed a nonsignificant difference between irradiated and non-irradiated minipigs $(P=0.10)$. However, if repeated measures ANCOVA was applied using primary implant stability as a covariate confounder to possible differences in ISQ values during follow-up, a statistically significant effect of the experimental irradiation factor was found. The overall 'time-by-group' effect showed $F=18.72$ by 3 and $9 \mathrm{df}$, 
$\mathrm{P}<0.001$ (correction by Greenhouse-Geisser epsilons is unnecessary) and the linear effect yielded $F=16.26$ by 1 and $3 \mathrm{df}, \mathrm{P}=0.027$. Irradiated minipigs tended to have slightly lower ISQ values immediately after implant placement and lower primary values tended to have a relatively less steep linear decrease in implant stability during follow-up. Therefore, the original ANOVA effect by irradiation had to be corrected or compensated for this tendency. On doing so, the corrected linear irradiation effect in ANCOVA would eventually be much steeper and become statistically significant. Conversion of the results to a dummyregression analysis showed that the original steepness effect (or linear decrease), expressed as a $\beta$ parameter, changed from $\beta=-0.64(P=0.174)$ to $\beta=-0.76(P=$ $0.027)$. Introducing another primary covariate into the model, i.e. primary bone vascularity, studying the conduct of the irradiation effect, was putting too much strain on the power of the corrected irradiation effect.

Analyzing the mean ISQ values, standard deviations, medians, and ranges at all 20 edentulous implant sites of the recordings immediately after implant placement and at 8, 16, and 24 weeks after implant placement separately for the maxilla and the mandible, the effect of irradiation on the decrease of ISQ values in the maxilla -corrected for primary maxillary implant stability - was not statistically significant $(F=1.39$ by 1 and 3 $\mathrm{df}, \mathrm{P}=0.323)$. However, the effect of the mandible as one within factor was significant $(F=16.52$ by 1 and $3 \mathrm{df}, \mathrm{P}=0.027$ ) (Table 2 ). 
Table 2. Implant stability quotient (ISQ) values, standard deviations, medians, and ranges at all 20 edentulous implant sites of the recordings immediatly after implant placement (primary) and at 8,16 , and 24 weeks after implant placement separately for the maxilla and the mandible

\begin{tabular}{lllll}
\hline Maxilla & Primary & $\mathbf{8}$ weeks & $\mathbf{1 6}$ weeks & 24 weeks \\
\hline Non-irradiated & & & & \\
Mean & 73.9 & 59.1 & 54.3 & 56 \\
Standard deviation & 3.8 & 6.1 & 6.8 & 8.1 \\
Median & 72 & 55.7 & 52.3 & 55.5 \\
Range & $71.3-78.3$ & $55.4-66.1$ & $48.7-61.8$ & $48.1-64.3$ \\
Irradiated & & & & \\
Mean & 75.5 & 45.6 & 44.2 & 44.7 \\
Standard deviation & 2.1 & 11.1 & 9.9 & 11.2 \\
Median & 76.2 & 50.8 & 49.7 & 50.7 \\
Range & $73.1-77.1$ & $32.9-53.2$ & $32.7-50.1$ & $31.8-51.5$ \\
\hline Mandible & Primary & $\mathbf{8}$ weeks & $\mathbf{1 6}$ weeks & $\mathbf{2 4}$ weeks \\
\hline Non-irradiated & & & & \\
Mean & 75.2 & 53.4 & 52.3 & 53.4 \\
Standard deviation & 1.4 & 6.1 & 6.6 & 6.7 \\
Median & 75.5 & 51.6 & 50.5 & 50.7 \\
Range & $73.7-76.4$ & $48.4-60.1$ & $46.9-59.6$ & $48.5-61.1$ \\
Irradiated & & & & \\
Mean & 71.4 & 37.5 & 37.9 & 37.9 \\
Standard deviation & 8.3 & 5.3 & 5 & 4.9 \\
Median & 71.5 & 37.8 & 38.4 & 38.5 \\
Range & $63.1-79.7$ & $32.1-42.7$ & $32.7-42.6$ & $32.7-42.4$ \\
\hline
\end{tabular}

\subsection{Discussion}

It can be concluded that immediately after implant placement, ISQ values were not statistically significant different in irradiated and non-irradiated alveolar bone. However, at 8 weeks after implant placement, a statistically significant difference in ISQ values was found between irradiated and non-irradiated alveolar bone. The reduction in ISQ values was more pronounced in irradiated than in non-irradiated alveolar bone. ISQ values of 16 and 24 weeks after implant placement showed a stabilization or even a slight increase, when compared with the values of 8 weeks after implant placement. The differences between irradiated and non-irradiated alveolar bone were still statistically significant. Significantly reduced bone regenerative capability and reduced implant osseointegration in irradiated dog and human alveolar bone have also been reported in previous studies (Granström et al. 1994, 1999; Nishimura et al. 1998; Granström, 
2005; Brasseur et al. 2006; Yerit et al. 2006). Bone loss and Periotest scores of early loaded implants were significantly higher in irradiated patients when compared with non-irradiated patients (Landes \& Kovács 2006). However, in contradiction with these findings, comparable satisfactory implant osseointegration was achieved in non-irradiated and irradiated dog alveolar bone (Brogniez et al. 2000; Brogniez et al. 2002). Furthermore, noncomparative studies showed (fairly) good implant survival results in irradiated alveolar human bone, whether or not in conjunction with hyperbaric oxygen therapy (Arcuri et al. 1997; Keller et al. 1997; Visch et al. 2002). Thus, the results of the studies are inconclusive. Many factors influencing implant osseointegration, such as irradiation dose, irradiation administration schedule, timing from radiotherapy to implantation, bone quality, bone volume, composition of implants, mandibular or maxillary location of implants, and usage of hyperbaric oxygen, make it difficult to compare studies.

The lack of difference in primary implant stability between irradiated and non-irradiated alveolar bone, as registered immediately after implant placement, was expected because primary implant stability is not related to bone vascularity, but only to bone density.

The more pronounced reduction of implant stability at 8 weeks after implant placement in irradiated alveolar bone suggests impaired integration in irradiated alveolar bone. This phenomenon was expected as well, because bone remodeling as a part of osseointegration is dependent on bone vascularity. Radiation has a significant decreasing effect on vascularity, as demonstrated by LDF (Verdonck et al. 2007).

The results of a recent study suggested reliable non-submerged implantation and early loading of implants in irradiated as well as nonirradiated oral cancer patients, in order to accelerate masticatory function improvement and quality of life (Landes \& Kovács 2006). However, in the current animal study $25 \%$ of implants lost in non-irradiated alveolar bone and even $60 \%$ of implants lost in irradiated alveolar bone failed during the first 8 weeks after implantation. Because relevant data of human studies on implant loss in irradiated patients are lacking, at least one should be very restraint with early loading of implants in these patients. Furthermore, implants placed in these patients require careful monitoring of implant stability and implant hygiene procedures during the first 2 months postplacement.

The Osstell instrument was used in several previous animal and human clinical implant stability studies (Balleri et al. 2002; Bischof et al. 
2004; Cornelini et al. 2004; Da Cunha et al. 2004; Farzad et al. 2004; Nedir et al. 2004; De Smet et al. 2005; Lachmann et al. 2006a, 2006b). The instrument was demonstrated to be reliable, useful, and precise in the long-term follow-up of oral implant osseointegration. Also in the current study, the instrument and RFA proved to be feasible for determining the stability of non-submerged implants during osseointegration. The measurements were consistent and the instrument as well as RFA demonstrated satisfactory clinical practice.

The minipigs received three irradiation (Cobalt) exposures up to $8 \mathrm{~Gy}$ at 7-day intervals, a total of $24 \mathrm{~Gy}$. Using an $\alpha / \beta$ ratio of 2.5 , this dose is biologically equivalent to approximately $56 \mathrm{~Gy}, 28$ exposures of $2 \mathrm{~Gy}$ each (Table 3).

The hypothesis of this study that during osseointegration implant stability is decreasing in a more pronounced manner in the irradiated minipigs when compared with the non-irradiated minipigs, has to be confirmed. The clinical significance and the origin of this phenomenon need to be elucidated in future studies. As shown previously, LDF is an adequate, reproducible, and reliable method for assessing alveolar bone vascularity (Verdonck et al. 2007). Whether research by LDF will provide a minimum level of vascularity allowing implant placement needs to be demonstrated.

Table 3. Calculation of the biological dose equivalent based on an alpha/beta ratio of 2.5 and a dose fraction of $2 \mathrm{~Gy}$, in the total effect (TE) equation: $\mathrm{TE}_{\mathrm{nfd}}=(\alpha / \beta+\mathrm{fd}) \mathrm{td}$

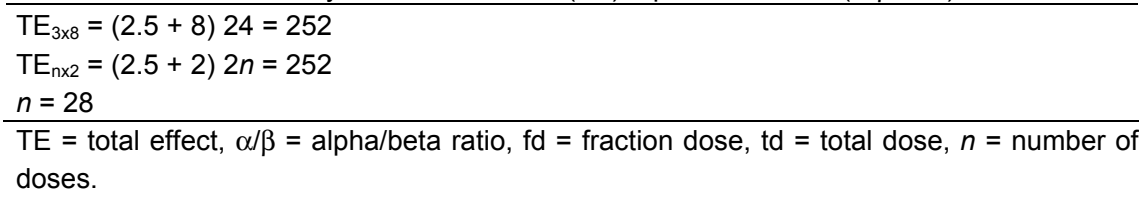




\section{References}

Albrektsson, T. \& Wennerberg, A. (2005) The impact of oral implants - past and future 1996-2042.Journal of the Canadian Dental Association 71:327.

Arcuri, M.R., Fridrich, K.L., Funk, G.F., Tabor, M.W. \& LaVelle, W.E. (1997) Titanium osseointegrated implants combined with hyperbaric oxygen therapy in previously irradiated mandibles. The Journal of Prosthetic Dentistry 77: 177-183.

Attard, N.J., David, L.A. \& Zarb, G.A. (2005) Immediate loading of implants with mandibular overdentures: one-year clinical results of a prospective study. International Journal of Prosthodontics 18: 463-470.

Balleri, P., Cozzolino, A., Ghelli, L., Momicchioli, G. \& Varriale, A. (2002) Stability measurements of osseointegrated implants using Osstell in partially edentulous jaws after 1 year of loading: a pilot Study. Clinical Implant Dentistry \& Related Research 4: 128-132.

Balshi, S.F., Allen, F.D., Wolfinger, G.J. \& Balshi, T.J. (2005) A resonance frequency analysis assessment of maxillary and mandibular immediately loaded implants. International Journal of Oral \& Maxillofacial Implants 20: 584-594.

Becker, W., Sennerby, L., Bedrossian, E., Becker, B.E. \& Lucchini, J.P. (2005) Implant stability measurements for implants placed at the time of extraction: a cohort, prospective clinical trial. Journal of Periodontology 76: 391-397.

Bischof, M., Nedir, R., Szmukler-Moncler, S., Bernard, J.P. \& Samson, J. (2004) Implant stability measurements of delayed and immediately loaded implants during healing. Clinical Oral Implants Research 15: 529-539.

Brånemark, P.I., Hansson, B.O., Adell, R., Breine, U., Lindstrom, J., Hallen, O. \& Ohman, A. (1977) Osseointegrated implants in the treatment of the edentulous jaw. Experience from a 10-year period. Scandinavian Journal of Plastic and Reconstructive Surgery 16 (Suppl.): 1-132.

Brasseur, M., Brogniez, V., Grégoire, V., Reychler, H., Lengele , B., D’Hoore, W. \& NyssenBehets, C. (2006) Effects of irradiation on bone remodelling around mandibular implants: an experimental study in dogs. International Journal of Oral and Maxillofacial Surgery 35: 850-855.

Brogniez, V., D'Hoore, W., Grégoire, V., Munting, E. \& Reychler, H. (2000) Implants placed in an irradiated dog mandible: a morphometric analysis. International Journal of Oral and Maxillofacial Implants 15: 511-518.

Brogniez, V., Nyssen-Behets, C., Grégoire, V., Reychler, H. \& Lengelé , B. (2002) Implant osseointegration in the irradiated mandible. A comparative study in dogs with a microradiographic and histologic assessment. Clinical Oral Implants Research 13: 234-242.

Carlsson, G.E., Kronström, M., de Baat, C., Cune, M., Davis, D., Garefis, P., Heo, S.J., Jokstad, A., Matsuura, M., Närhi, T., Ow, R., Pissiotis, A., Sato, H. \& Zarb, G.A. (2004) A survey of the use of mandibular implant overdentures in 10 countries. International Journal of Prosthodontics 17:211-217.

Chavez, J.A. \& Adkinson, C.D. (2001) Adjunctive hyperbaric oxygen in irradiated patients requiring dental extractions: outcomes and complications. International Journal of Oral and Maxillofacial Surgery 59: 518-522.

Cornelini, R., Cangini, F., Covani, U., Barone, A. \& Buser, D. (2004) Immediate restoration of single-tooth implants in mandibular molar sites: a 12-month preliminary report. International Journal of Oral \& Maxillofacial Implants 19: 855-860. 
Da Cunha, H.A., Francischone, C.E., Filho, H.N. \& de Oliveira, R.C. (2004) A comparison between cutting torque and resonance frequency in the assessment of primary stability and final torque capacity of standard and TiUnite single-tooth implants under immediate loading. International Journal of Oral \& Maxillofacial Implants 19:578-585.

De Smet, E., Jaecques, S., Vandamme, K., Vander Sloten, J. \& Naert, I. (2005) Positive effect of early loading on implant stability in the bicortical guinea-pig model. Clinical Oral Implants Research 16: 402-407.

Ersanli, S., Karabuda, C., Beck, F. \& Leblebicioglu, B. (2005) Resonance frequency analysis of one stage dental implant stability during the osseointegration period. Journal of Periodontology 76: 1066-1071.

Farzad, P., Andersson, L., Gunnarssson, S. \& Sharma, P. (2004) Implant stability, tissue conditions, and patient self-evaluation after treatment with osseointegrated implants in the posterior mandible. Clinical Implant Dentistry Related Research 6: 24-32.

Faulkner, M.G., Giannitsios, D., Lipsett, A.W. \& Wolfaardt, J.F. (2001) The use and abuse of the Periotest for 2-piece implant/abutment systems. International Journal of Oral \& Maxillofacial Implants 16: 486-494.

Gallucci, G.O., Bernard, J.P., Bertosa, M. \& Belser, U.C. (2004) Immediate loading with fixed screwretained provisional restorations in edentulous jaws: the pickup technique. International Journal of Oral \& Maxillofacial Implants 19: 524-533.

Granstro m, G., Bergstro m, K., Tjellstro m, A. \& Brånemark, P.-I. (1994) A detailed analysis of titanium implants lost in irradiated tissues. International Journal of Oral \& Maxillofacial Implants 9: 653-662.

Granström, G., Tjellström, A. \& Brånemark, P.-I. (1999) Osseointegrated implants in irradiated bone: a case-controlled study using adjunctive hyperbaric oxygen therapy. International Journal of Oral and Maxillofacial Surgery 57: 493-499.

Granström, G. (2005) Osseointegration in irradiated cancer patients: an analysis with respect to implant failures. International Journal of Oral and Maxillofacial Surgery 63: 579-585.

Grotz, K.A., Al-Nawas, B., Piepkorn, B., Reichert, T.E., Duschner, H. \& Wagner, W. (1999) Micromorphological findings in jaw bone after radiotherapy. Mund-, Kiefer- und Gesichtschirurgie 3:140-145.

Keller, E.E., Tolman, D.E., Zuck, S.L. \& Eckert, S.E. (1997) Mandibular endosseous implants and autogenous bone grafting in irradiated tissue: a 10-year retrospective study. International Journal of Oral \& Maxillofacial Implants 12:800-813.

Lachmann, S., Jager, B., Axmann, D., Gomez-Roman, G., Groten, M. \& Weber, H. (2006a) Resonance frequency analysis and damping capacity assessment. Part I: an in vitro study on measurement reliability and a method of comparison in the determination of primary dental implant stability. Clinical Oral Implants Research 17: 75-79.

Lachmann, S., Laval, J.Y., Jager, B., Axmann, D., Gomez-Roman, G., Groten, M. \& Weber, H.(2006b) Resonance frequency analysis and damping capacity assessment. Part 2: peri-implant bone loss follow-up. An in vitro study with the Periotest and Osstell instrument. Clinical Oral Implants Research 17: 80-84.

Landes, C.A. \& Kovács, A.F. (2006) Comparison of early telescope loading of nonsubmerged ITI implants in irradiated and non-irradiated oral cancer patients. Clinical Oral Implants Research 17: 367-374.

Lindquist, L.W., Carlsson, G.E. \& Jemt, T. (1996) A prospective 15-year follow-up study of mandibular prostheses supported by osseointegrated implants. Clinical results and marginal bone loss. Clinical Oral Implants Research 7: 329-336. 
Meredith, N. (1998) A review of nondestructive test methods and their application to measure the stability and osseointegration of bone anchored endosseous implants. Critical Reviews in Biomedical Engineering 26: 275-291.

Meredith, N., Alleyne, D. \& Cawley, P. (1996) Quantitative determination of the stability of the implant-tissue interface using resonance frequency analysis. Clinical Oral Implants Research 7: 261-267.

Meredith, N., Shagaldi, F., Alleyne, D., Sennerby, L. \& Cawley, P. (1997) The application of resonance frequency measurements to study the stability of titanium implants during healing in the rabbit tibia. Clinical Oral Implants Research 8: 234-243.

Nedir, R., Bischof,M., Szmukler-Moncler, S., Bernard, J.P. \& Samson, J. (2004) Predicting osseointegration by means of implant primary stability. Clinical Oral Implants Research 15: $520-528$.

Nishimura, R.D., Roumanas, E., Beumer III, J., Moy, P.K. \& Shimizu, K.T. (1998) Restoration of irradiated patients using osseointegrated implants: current perspectives. The Journal of Prosthetic Dentistry 79: 641-647.

Nkenke, E., Lehner, B., Fenner, M., Roman, F.S., Thams, U., Neukam, F.W. \& RadespielTroger, M. (2005) Immediate versus delayed loading of dental implants in the maxillae of minipigs: follow-up of implant stability and implant failures. International Journal of Oral \& Maxillofacial Implants 20: 39-47.

Olsson,M., Urde, G., Andersen, J.B. \& Sennerby, L. (2003) Early loading of maxillary crossarch dental prostheses supported by six or eight oxidized titanium implants: results after 1 year of loading, case series. Clinical Implant Dentistry \& Related Research 5 (Suppl. 1): $81-87$.

Ostman, P.O., Hellman, M. \& Sennerby, L. (2005) Direct implant loading in the edentulous maxilla using a bone density-adapted surgical protocol and primary implant stability criteria for inclusion. Clinical Implant Dentistry \& Related Research 7 (Suppl. 1): S60-S69.

Sennerby, L., Persson, L.G., Berglundh, T., Wennerberg, A. \& Lindhe, J. (2005) Implant stability during initiation and resolution of experimental periimplantitis: an experimental study in the dog. Clinical Implant Dentistry \& Related Research 7: 136-140.

Szmukler-Moncler, S., Salama, H., Reingewirtz, Y.\& Dubruille, J. (1998) Timing of loading and effect of micromotion on bone-dental implant interface: review of experimental literature. Journal of Biomedical Materials Research 43:192-203.

Van Steenberghe, D., Naert, I., Jacobs, R. \& Quirynen, M. (1999) Influence of inflammatory reactions vs. occlusal loading on peri-implant marginal bone level. Advances in Dental Research 13: 130-135.

Vanden Bogaerde, L., Rangert, B. \& Wendelhag, I. (2005) Immediate/early function of Brånemark System TiUnite implants in fresh extraction sockets in maxillae and posterior mandibles: an 18-month prospective clinical study. Clinical Implant Dentistry \& Related Research 7 (Suppl. 1): S121-S130.

Verdonck, H.W.D., Meijer, G.J., Laurin, T., Nieman, F.H.M., Stoll, C., Riediger, D., Stoelinga, P.J.W. \& de Baat, C. (2007) Assessment of vascularity in irradiated and nonirradiated maxillary and mandibular alveolar minipig bone using laser Doppler flowmetry. International Journal of Oral and Maxillofacial Implants 22: 774-778

Visch, L.L., van Waas, M.A.J., Schmitz, P.I.M. \& Levendag, P.C. (2002) A clinical evaluation of implants in irradiated oral cancer patients. Journal of Dental Research 81: 856-859.

Yerit, K.C., Posch, M., Seemann, M., Hainich, S., Dörtbudak, O., Turhani, D., Özyuvaci, H., Watzinger, F. \& Ewers, R. (2006) Implant survival in mandibles of irradiated oral cancer patients. Clinical Oral Implants Research 17: 337-344. 
Zix, J., Kessler-Liechti, G. \& Mericske-Stern, R. (2005) Stability measurements of 1-stage implants in the maxilla by means of resonance frequency analysis: a pilot study. International Journal of Oral \& Maxillofacial Implants 20: 747-752. 


\section{CHAPTER 4}

Quantitative computed tomography bone mineral density measurements in irradiated and non-irradiated minipig alveolar bone: an experimental study

Clin Oral Implants Res 2008; 19: 465-468.
H.W.D. Verdonck
G.J. Meijer
F.H. Nieman
C. Stoll
D. Riediger
C. de Baat 


\subsection{Introduction}

Osseointegration of oral implants depends on many factors, such as bone mineral density (BMD), bone volume, bone vascularity, implant design, implant surface, and residual alveolar ridge shape (Devlin et al. 1998; Duyck \& Naert 1998; Steigenga et al. 2003; Brånemark 2005; Amorim et al. 2006; Butz et al. 2006; Le Guehennec et al. 2007; Shalabi et al. 2006; Traini et al. 2006). The deleterious effects of irradiation on bone have been recognized for almost a century and still continue to be a problem even today because of improved survival of patients treated with radiotherapy for oral and neck cancer. Irradiation causes a spectrum of changes from mild osteopaenia, through disordered wound healing with varying degrees of bone sclerosis, to osteoradionecrosis, which ultimately may lead to bone fracture following minimal trauma (Zarem \& Carr 1983; Williams \& Davies 2006). Bone sclerosis manifests as increased BMD, which is defined as mineral mass per unit volume (Rauch \& Schoenau 2001). Osteoradionecrosis is a complex of cellular deaths and cellular functional impairments from radiation energy transfers. Therefore, the pathogenesis of osteoradionecrosis is far more multifaceted than originally believed (Marx \& Johnson 1987; Teng \& Futran 2005). Restoration of blood supply or transplantation of vascularized tissue to the affected area is of primary significance in the resolution of osteoradionecrosis (Teng \& Futran 2005).

Quantitative computed tomography (QCT) provides a site-related measure of BMD and is useful as a non-invasive method for determining a parameter reflecting bone quality before implant placement (Lindh et al. 1996; Shahlaie et al. 2003). BMD is calculated by measuring Hounsfield units $(\mathrm{HU})$ and relating those values to a calibration bone phantom with a pre-determined BMD (Todisco \& Trisi 2005). HU can be measured by the Simplant ${ }^{\mathrm{TM}}$ implant planning software. Using QCT, an objective scale of BMD based on the Hounsfield scale can be established (Norton \& Gamble 2001).

In a previous research project, it was demonstrated that 3 months after irradiation, alveolar bone appeared less vascularized in irradiated than in non-irradiated minipigs (Verdonck et al. 2007). Furthermore, 8, 12 , and 24 weeks after implant placement, in 3-month previously irradiated minipigs, a more pronounced decrease in implant stability was observed than in non-irradiated minipigs (Verdonck et al. 2008). Subsequently, the question arises as to whether irradiation affects BMD due to 
bone sclerosis. In order to address this question, the hypothesis of this study was that BMD is increased in irradiated maxillary and mandibular minipig alveolar bone, when compared with non-irradiated maxillary and mandibular minipig alveolar bone.

\subsection{Material and methods}

Six adult 1-year-old Göttingen minipigs were used for this study. The experiments were conducted in accordance with German and European community guidelines on the protection of (laboratory) animals. Permission was obtained from the Animal Ethical Committee of the University of Aachen.

All maxillary and mandibular pre-molars and molars of the minipigs were extracted under general anaesthesia, induced by Isoflorane ${ }^{\mathrm{TM}} 0.8-$ $1.1 \%$. Inter- and postoperatively during 3 days, clindamycine was administered as the antimicrobial agent, prophylactically. After a 3-month alveolar bone healing period, the maxillary and mandibular bones of three minipigs received bilaterally three irradiation (Cobalt) exposures up to 8 Gray (Gy) with 7-day intervals at a total dose of $24 \mathrm{~Gy}$. The right- as well as the left-sided irradiation field contained half of the maxilla as well as the mandible completely, obtaining an even irradiation distribution of arches and jaws.

At 3 months after irradiation, QCT scans of all minipigs were performed under general anaesthesia. The scanner used was the SOMATOM Sensation $^{\mathrm{TM}}$ (Siemens Nederland N.V., The Hague, The Netherlands), which produces a reconstructed slice distance of $1 \mathrm{~mm}$. During scanning, a calibration bone phantom with a pre-determined BMD (Image Analysis, Inc, Columbia, KY, USA) was attached to the head of the minipigs. QCT images are a pixel map of the linear $\mathrm{X}$-ray attenuation coefficient of tissue. The pixel values are scaled so that the linear $\mathrm{X}$-ray attenuation coefficient of air equals -1024 and of water equals 0 . This scale is called the Hounsfield scale. Using this scale, fat tissue is around -110 , muscle tissue is around 40 , trabecular bone is in the range of $100-$ 300 , and cortical bone extends above trabecular bone to about 2000 (Hounsfield 1980).The QCT data were imported into a software program (Simplant ${ }^{\mathrm{TM}}$, Materialise N.V., Leuven, Belgium), compressing the original 12-bit images to eight-bit images. Simplant ${ }^{T M}$ displays the QCT images using up to 256 grey levels. The default grey scale used by Simplant ${ }^{\mathrm{TM}}$ 
allows one to see the full range of tissue from air in the maxillary sinus to the densest cortical bone. Also using QCT and Simplant ${ }^{\mathrm{TM}}$ software, virtually precise implant positions were determined in the alveolar bone and an additional implant in the calibration bone phantom. Using a customized surgical template (Materialise N.V.) and a pilot drill, five initial osteotomy sites were drilled in the residual alveolar ridge of each edentulous site, in total 20 osteotomy sites in each minipig. Implant placement was carried out as part of an ongoing study on the effects of irradiation on implant stability and implant survival (Verdonck et al. 2007, 2008).

The peri-implant BMD, both of the alveolar bone and of the calibration bone phantom, was calculated using the examiner-independent Simplant $^{\mathrm{TM}}$ software. The alveolar BMD around all 20 virtual osteotomy sites in each minipig was calculated in the software program automatically. BMD calculation was carried out at each osteotomy site because during the procedure of implant placement, bone vascularity and implant stability would be measured at each osteotomy site as well (Verdonck et al. 2007, 2008). In order to compare the BMD values of individual minipigs, it was necessary to calculate an absolute value of BMD. The so-called bone mineral density quotient (BMDQ) was created, dividing the peri-implant $B M D$ value of the alveolar bone by the peri-implant $B M D$ value of the calibration bone phantom (Todisco \& Trisi 2005).

The Kolmogorov-Smirnov test on the normality of the distribution of BMDQ was carried out separately on maxillary, mandibular, and overall peri-implant BMDQ. For each minipig, mean maxillary, mandibular, and overall peri-implant BMDQ values together with the standard deviations of the 20 implants were calculated. Because the intra-minipig peri-implant $B M D Q$ values are correlated intrinsically, it was obvious to consider the 10 maxillary, the 10 mandibular, and the 20 overall peri-implant BMDQ values per minipig as 1 mean peri-implant BMDQ value, respectively. In other words, each minipig alone was an independently recorded unit for the data analysis. Independent groups Student $t$-tests and Mann-Whitney tests for determining the irradiation effect were also carried out on three separate BMDQ parameters. Paired $t$-test and Wilcoxon signed-rank test were performed on the differences between mandibular and maxillary BMDQ values. A $P$-value of 0.05 was considered to be statistically significant. Data analysis was performed by SPSS-pc version 12 . 


\subsection{Results}

Although the calibration bone phantom had a pre-determined BMD, different individual peri-implant BMD values were measured per minipig, using the Simplant ${ }^{\mathrm{TM}}$ software, varying from 160 to 250 (Table 1). Table 2 presents the means and standard deviations of the maxillary, the mandibular, and the overall peri-implant BMDQ separately for the three nonirradiated and the three irradiated minipigs. The Kolmogorov-Smirnov test showed no deviations from the normality of statistical distribution for mean maxillary peri-implant BMDQ $(P=0.79)$, mean mandibular periimplant BMDQ $(P=0.76)$, and mean overall peri-implant BMDQ $(P=0.95)$ of the six minipigs. Both the maxillary and mandibular as well as the overall peri-implant BMDQ showed higher mean values in irradiated minipigs, when compared with non-irradiated minipigs, but the differences were not statistically significant. The $P$-values of the Student $t$-test, determining the irradiation effect, were 0.11 for the maxillary, 0.14 for the mandibular, and 0.07 for the overall peri-implant BMDQ. P-values of the non-parametric Mann-Whitney test were all 0.05. In irradiated and nonirradiated minipigs, the mean mandibular peri-implant BMDQ values were higher when compared with the mean maxillary peri-implant BMDQ values (paired $t$-test, $P=0.003$; Wilcoxon, $P=0.028$ ).

Table 1. Peri-implant BMD values of the six calibration bone phantoms, measured in Hounsfield units

\begin{tabular}{ll}
\hline Calibration bone phantom & BMD \\
\hline 1 & 250 \\
2 & 184 \\
3 & 173 \\
4 & 189 \\
5 & 160 \\
6 & 202 \\
\hline
\end{tabular}

BMD, bone mineral density 
Table 2. Means and standard deviations (SD) of maxillary, mandibular, and overall peri-implant BMDQ of the three non-irradiated (one to three) and the three irradiated (four to six) minipigs

\begin{tabular}{llll}
\hline Minipigs & Maxillary BMDQ & Mandibular BMDQ & Overall BMDQ \\
\hline Non-irradiated & & & \\
1 & 3.53 & 4.53 & 4.03 \\
2 & 3.08 & 3.74 & 3.41 \\
3 & 2.89 & 4.4 & 3.65 \\
Mean \pm SD & $3.17 \pm 0.33$ & $4.22 \pm 0.42$ & $3.69 \pm 0.31$ \\
& & & \\
Irradiated & & & \\
4 & 3.55 & 4.55 & 4.05 \\
5 & 4.41 & 4.67 & 4.54 \\
6 & 3.6 & 4.86 & 4.23 \\
Mean \pm SD & $3.85 \pm 0.48$ & $4.69 \pm 0.15$ & $4.27 \pm 0.25$ \\
Non-irradiated + Irradiated & & & \\
Mean \pm SD & $3.51 \pm 0.53$ & $4.46 \pm 0.38$ & $3.98 \pm 0.41$ \\
\hline
\end{tabular}

$\mathrm{BMDQ}$, bone mineral density quotient.

\subsection{Discussion}

The data presented in Table 1 show a wide range of peri-implant BMD values in the six calibration bone phantoms. Consequently, it was shown that calculating absolute BMD values based on computed tomography (CT) scans and using the Simplant ${ }^{\mathrm{TM}}$ software is not possible, unless calibration bone phantoms with a pre-determined BMD value are coscanned. The number of minipigs participating in this study was determined by statistical power calculation, based on implant stability and bone vascularity. As a consequence, the statistical power for BMD could be low. An alternative would have been to increase the number of minipigs, but this alternative was rejected from an ethical point of view. Nevertheless, statistical analysis showed a nearly significant difference between peri-implant BMDQ in the irradiated and the non-irradiated minipigs. Presumably, a statistically significant correlation would have been reached if more minipigs would have been used for this study.

The minipigs received three irradiation (Cobalt) exposures up to $8 \mathrm{~Gy}$ with 7-day intervals, at a total dose of $24 \mathrm{~Gy}$. Using an $\alpha / \beta$ ratio of 2.5 , this dose is biologically equivalent to approximately $56 \mathrm{~Gy}, 28$ exposures of $2 \mathrm{~Gy}$ each (Table 3). The higher peri-implant BMDQ values in irradiated minipigs, when compared with non-irradiated minipigs, suggest a sclerotic effect of irradiation on BMD. Although likely, it is not certain that a similar irradiation effect will be observed in humans. 
Table 3. Calculation of the biological dose equivalent based on an alpha/beta ratio of 2.5 and a dose fraction of $2 \mathrm{~Gy}$, in the total effect (TE) equation: $\mathrm{TE}_{\mathrm{nfd}}=(\alpha / \beta+\mathrm{fd}) \mathrm{td}$

$\mathrm{TE}_{3 \times 8}=(2.5+8) 24=252$

$\mathrm{TE}_{\mathrm{n} \times 2}=(2.5+2) 2 n=252$

$n=28$

$\mathrm{TE}=$ total effect, $\alpha / \beta=$ alpha/beta ratio, $\mathrm{fd}=$ fraction dose, $\mathrm{td}=$ total dose, $n=$ number of doses.

When importing original 12-bit images in Simplant ${ }^{\mathrm{TM}}$, the images are compressed to eight-bit ones. The lower part of the Hounsfield scale is cut off, in the sense that pixels between 0 and 200 are mapped on 0 . The compression of images has limited influence because the 0-200 range does not contain CT-critical data, but mainly air scattering. Afterwards, Simplant ${ }^{\mathrm{TM}}$ maps optimally the 12 -bit range ( $4096 \mathrm{HU}$ values) to eight-bit (256 grey values) ones. Hence, the range from 201 to the maximal $\mathrm{HU}$ value (4095) in the CT images is divided in 255 intervals. In the worst case, the 255 intervals have a width of approximately $16 \mathrm{HU}$ $\left(\approx \frac{4095-201}{255}=15.27\right)$, introducing an error of $16 \mathrm{HU}$ maximally. Moreover, the maximum error of $16 \mathrm{HU}$, resulting from the image reduction from 12bit to eight-bit, is in general much smaller than the differences between the measured peri-implant BMD values, indicating that the differences result from differences in material properties. Consequently, this procedure has limited or no influence on CT image quality, but reduces the data set to simplify the statistical analyses substantially (Chen et al. 2004). Very recently, several manufacturers announced new display systems with higher bit depth and increased the available number of gray scales to 1.024 (Kimpe \& Tuytschaever 2007).

Based on the results of this study, it could be concluded that, 3 months after irradiation, the peri-implant BMD of irradiated alveolar minipig bone was increased, when compared with non-irradiated alveolar minipig bone, suggesting an increase of BMD by irradiation. However, the increase was not statistically significant. Moreover, as measured with laser Doppler flowmetry, at 3 months after irradiation, edentulous alveolar bone appeared less vascularized in irradiated than in non-irradiated minipigs (Verdonck et al. 2007). Furthermore, it was demonstrated that during osseointegration, implant stability decreased at a more pronounced rate in irradiated minipigs, when compared with non-irradiated minipigs (Verdonck et al. 2008). The results of these three studies are in agreement with previous studies, indicating bone sclerosis following irradiation 
and highlighting BMD as well as bone vascularity as parameters of bone quality (Zarem \& Carr 1983; Williams \& Davies 2006). High BMD values are in accordance with reduced bone vascularity. Sclerosis and reduced vascularity are biological changes in irradiated bone, which are responsible for reduced implant stability during and after osseointegration and high implant loss figures.

The important question of this minipig study and the two previous minipig studies (Verdonck et al. 2007, 2008) is whether the results will be similar in humans. If so, the clinical implications could be that, in order to reduce implant loss and the risk of osteoradionecrosis in patients irradiated in the head and neck region before implant placement, bone vascularity and/or BMD should be measured. Perhaps, below a specific to determine level of bone vascularity and/or above a specific to determine level of BMD implant placement should be abandoned. Bone vascularity and BMD with regard to implant placement should be subject to further investigation with a proper study design and sufficient animal or patient numbers.

\section{Acknowledgements}

The authors are grateful to Biocomp Industries for generously putting at disposal their instruments and implants, and to Dr. Michael J. Eble and Dr. Elmar Spüntrup, Klinikum Aachen, Germany, for their contributions to this study. 


\section{References}

Amorim, M.A., Takayama, L., Jorgetti, V. \& Pereira, R.M. (2006) Comparative study of axial and femoral bone mineral density and parameters of mandibular bone quality in patients receiving dental implants. Osteoporosis International 317: 1494-1500.

Brånemark, P-I. (2005) The Osseointegration Book. From Calvarium to Calcaneus. Berlin: Quintessenz Verlags-GmbH.

Butz, F., Aita, H., Wang, C.J. \& Ogawa, T. (2006) Harder and stiffer bone osseointegrated to roughened titanium. Journal of Dental Research 385: 560-565.

Chen, T.J., Chuang, K.S., Chiang, Y.C., Chang, J.H. \& Liu, R.S. (2004) A statistical method for evaluation quality of medical images: a case study in bit discarding and image compression. Computerized Medical Imaging and Graphics 328: 167-175.

Devlin, H., Horner, K. \& Ledgerton, D. (1998) A comparison of maxillary and mandibular bone mineral densities. The Journal of Prosthetic Dentistry 379: 323-327.

Duyck, J. \& Naert, I. (1998) Failure of oral implants: aetiology, symptoms and influencing factors. Clinical Oral Investigations 32: 102-114.

Le Guehennec, L., Soueidan, A., Layrolle, P. \& Amouriq, Y. (2007) Surface treatments of titanium dental implants for rapid osseointegration. Dental Materials 323: 844-854.

Hounsfield, G.N. (1980) Nobel lecture, 8, December 1979. Computed medical imaging. Journal of Radiology 361: 459-468.

Kimpe, T. \& Tuytschaever, T. (2007) Increasing the number of gray shades in medical display systems - how much is enough? Journal of Digital Imaging 320: 422-432.

Lindh, C., Nilsson, M., Klinge, B. \& Petersson, A. (1996) Quantitative computed tomography of trabecular bone in the mandible. Dentomaxillofacial Radiology 325: 146-150.

Marx, R.E. \& Johnson, R.P. (1987) Studies in the radiobiology of osteoradionecrosis and their clinical significance. Oral Surgery, Oral Medine, and Oral Pathology 364: 379-390.

Norton, M.R. \& Gamble, C. (2001) Bone classification: an objective scale of bone density using the computerized tomography scan. Clinical Oral Implants Research 312: 79-84.

Rauch, F. \& Schoenau, E. (2001) Changes in bone density during childhood and adolescence: an approach based on bone's biological organization. Journal of Bone and Mineral Research 316: 597-604.

Shahlaie, M., Gantes, B., Schulz, E., Riggs, M. \& Crigger, M. (2003) Bone density assessments of dental implant sites: 1. Quantitative computed tomography. International Journal of Oral \& Maxillofacial Implants 318: 224-231.

Shalabi, M.M., Gortemaker, A., Van 't Hof, M.A., Jansen, J.A. \& Creugers, N.H.J. (2006) Implant surface roughness and bone healing: a systematic review. Journal of Dental Research 385: 496-500.

Steigenga, J.T., al-Shammari, K.F., Nociti, F.H., Misch, C.E. \& Wang, H.L. (2003) Dental implant design and its relationship to long-term implant success. Implant Dentistry 312: 306-317.

Teng, M.S. \& Futran, N.D. (2005) Osteoradionecrosis of the mandible. Current Opinion in Otolaryngology \& Head and Neck Surgery 313: 217-221.

Todisco, M. \& Trisi, P. (2005) Bone mineral density and bone histomorphometry are statistically related. International Journal of Oral \& Maxillofacial Implants 320: 898-904.

Traini, T., Assenza, B., San Roman, F., Thams, U., Caputi, S. \& Piattelli, A. (2006) Bone microvascular pattern around loaded dental implants in a canine model. Clinical Oral Investigations 310: 151-156. 
Verdonck, H.W.D., Meijer, G.J., Nieman, F., Laurin, T., Stoll, C., Riediger, D., Stoelinga, P.J.W. \& de Baat, C. (2007) Assessment of vascularity in irradiated and non-irradiated maxillary and mandibular alveolar minipig bone using laser Doppler flowmetry. International Journal of Oral \& Maxillofacial Implants 322: 774-778.

Verdonck, H.W.D., Meijer, G.J., Nieman, F., Laurin, T., Stoll, C., Riediger, D., Stoelinga, P.J.W. \& de Baat, C. (2008) Implant stability during osseointegration in irradiated and non-irradiated minipig alveolar bone: an experimental study. Clinical Oral Implants Research 319: 201-206.

Williams, H.J. \& Davies, A.M. (2006) The effect of X-rays on bone: a pictorial review. European Radiology 316: 619-633.

Zarem, H.A. \& Carr, R. (1983) Salvage of the exposed irradiated mandible. Plastic and Reconstructive Surgery 372: 648-655. 


\section{CHAPTER 5}

\section{Assessment of bone vascularity in the anterior mandible using laser Doppler flowmetry}

Accepted for publication in Clin Oral Implants Res
H.W.D. Verdonck
G.J. Meijer
P. Kessler
F.H. Nieman
C. de Baat
P.J.W. Stoelinga 


\subsection{Introduction}

According to the literature, it is generally accepted that oral implant integration in irradiated bone is impaired (Cawood \& Stoelinga 2006; Weinlaender et al. 2006). Oral implant survival percentages in irradiated bone are lower than in non-irradiated bone, particularly if the irradiation dose exceeds 50 Gray (Granström et al. 1999; Visch et al. 2002; Granström 2005; Yerit et al. 2006). Prospective studies have shown that irradiated bone becomes hypocellular and hypoxic and that the vascularity of irradiated bone is decreasing over time (Marx 1983). In irradiated patients, a method of measuring vascularity of intended implant recipient bone would be of clinical significance in preventing early implant loss and in reducing the risk of osteoradionecrosis due to surgical interventions, such as oral implant insertion. Eventually, it could be possible to establish a threshold bone vascularity value beyond which oral implants should not be inserted.

For assessment of tissue vascularity, non-invasive laser Doppler flowmetry (LDF) has been applied in skin, colonic, muscular, gingival, pulpal, and oral mucosal tissues (Donos et al. 2005; Kocabalkan \& Turgut, 2005; Mavropoulos et al. 2007; Retzepi et al. 2007; Seike et al. 2007; von Arx et al. 2007; Emshoff et al. 2008; Rajan et al. 2008, Røe et al. 2008; Singh et al. 2008). Several animal and a few clinical human studies assessing bone vascularity by LDF have also been carried out (Beaulé et al. 2006; Murnaghan et al. 2006; Beaulé et al. 2007). At present, assessing jaw bone vascularity clinically, using LDF, seems to be realistic. A recent animal study, using LDF, showed a significant decrease of jaw bone vascularity after irradiation (Verdonck et al. 2007). Hence, it was suggested to use the method clinically, increasing the predictability of oral implant treatments. However, to prove the method to be useful in human beings, normal values of human jaw bone vascularity measured by LDF should be known. Assessment of bone vascularity in the anterior mandible is important particularly, because the effect of radiation therapy is more pronounced in the mandible compared to the maxilla (Verdonck et al. 2007). Modern LDF techniques are using a laser diode device producing a beam of near-infrared laser light with an operating wavelength of 780 to $820 \mathrm{~nm}$, beaming into human tissues by a fiber optic connector (probe) (Bollinger \& Partsch 2003; Michelson et al. 1996). The photons are scattered and light, hitting moving blood cells, undergoes a change in wavelength (Doppler shift), while the wavelength of the light hitting static 
structures is unchanged. A returning fiber in the probe picks up the light and carries it back to a photo detector. The magnitude of the signal and the frequency changes are directly related to the relative number and velocity of blood cells in a recorded volume (Ahn et al. 1987).

The hypotheses of this study were that bone vascularity in the human anterior mandible can be assessed during implant insertion by LDF and that the recorded LDF values are providing standard data for bone vascularity in the human anterior mandible.

\subsection{Material and methods}

Twenty-three randomly selected non-irradiated edentulous patients scheduled for treatment with oral implants in the anterior mandible were assigned; 12 men and 11 women aged 42 to 78 years, mean age 63.6 years and median age 64.6 years. The patient's history of edentulousness ranged from 3 months to 40 years, median 2 years. According to the classification of Cawood and Howell (1988) the resorption of the residual alveolar ridges was determined class III in 6 patients, class IV in 7 patients, class $\mathrm{V}$ in 5 patients, and class $\mathrm{VI}$ in 5 patients.

The surgical implant treatment included an incision over the top of the anterior mandibular alveolar crest and lateral release incisions sloping into the buccal vestibule and a gently reflection of the periosteum, exposing the underlying alveolar bone. If and where necessary the alveolar process was trimmed for inserting implants with a diameter of $4.3 \mathrm{~mm}$. Subsequently, pilot osteotomy sites were drilled for recording bone vascularity, using a drill with a diameter of $3.0 \mathrm{~mm}$. The LDF module, calibrated according to the manufacturer's instructions, emitted laser light of $780 \mathrm{~nm}$, which was transduced to the pilot osteotomy site by a special side reading optical fiber probe with a diameter of $2.8 \mathrm{~mm}$ (PF 415-254, Periflux System $\circledast$, Perimed, Sweden) (Fig. 1). Penetration of the light into bone tissue was found to be $3 \mathrm{~mm}$ from the bone surface approximately (Nötzli et al. 1989). Because of the merely $0.1 \mathrm{~mm}$ gap between probe and bone in the pilot osteotomy site, reflection of the light was precluded practically. No repeated recordings at various moments were carried out, preventing the requirement of producing a fixation device. The probe was inserted in the pilot osteotomy site at a standard depth of $8 \mathrm{~mm}$. Before inserting the probe, the pilot osteotomy site was rinsed with a saline solution avoiding contamination. 


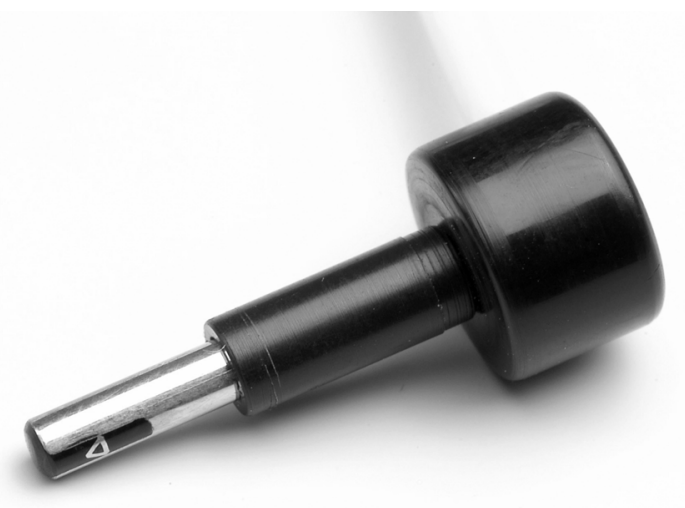

Figure 1. Side reading LDF probe.

While recording the blood flow, the patient sitting in a semi-reclined position in a dental chair, was requested to avoid disturbing movements. Disturbing movements of the patient, if any, became promptly apparent in the recording graphic. Within a few seconds after installing the probe, however, the graphic stabilized and remained stable during the recording period. A 20 seconds noise free period appeared sufficient for a reliable recording session. Because of the non-homogenous calcified and trabecular bone, as demonstrated in a previous animal study (Verdonck et al. 2007), in each pilot osteotomy site 4 LDF recordings were carried out with the probe perpendicularly directed to the mesial, buccal, distal, and lingual pilot osteotomy site wall successively. In the same animal study was concluded that because of the sufficient intraclass correlation coefficient one recording session per pilot osteotomy site was adequate. The LDF module was connected to a personal computer for calculating the recordings. The recordings in the 4 directions were averaged, revealing the blood flow per pilot osteotomy site, expressed in perfusion units (PU). Although PU is an arbitrary unit, a linear relationship between PU and blood flow expressed in $\mathrm{ml} / \mathrm{min} / 100 \mathrm{~g}$ has been demonstrated (Weinlaender et al. 2006). If more than one implant was scheduled, the recording value of each pilot osteotomy site was considered a separate value. LDF recordings were carried out at 1 pilot site in 7 patients, at 2 sites in 15 patients, and at 4 sites in 1 patient. At a total of 41 pilot osteotomy sites LDF values were thus recorded, 19 in the 12 men and 22 in 
the 11 women. After the LDF recordings, the pilot osteotomy sites were widened for inserting the implants.

The statistical distribution and characteristics of the main outcome parameter of the study (LDF value) were explored, separately for men and women. Due to the limited number of recordings not only the mean values and the standard deviations were provided, but also the medians and ranges. The Kolmogorov-Smirnov test on the normality of the distribution of LDF was carried out. Student $t$-test, Mann-Whitney test, and Levene test for determining the gender effect on LDF values were carried out. The relationship between patient's LDF values at one hand and patient's age and history of edentulousness at the other hand was determined by Spearman's rank correlation coefficient $(R)$. All data were analyzed by SPSS-pc, version 12.0 and 15.0. $P$-value 0.05 was determined as level of significance for all comparisons.

\subsection{Results}

Mean LDF value of the 41 pilot osteotomy sites was $25.80 \mathrm{PU}$, median 20.82, range 7.97-61.95, and standard deviation 12.58 (Table 1-2).

The Kolmogorov-Smirnov test showed no deviations from normality of statistical distribution for mean LDF value $(P=0.15)$. However, a strong tendency of positive skewness with a tail to the right was obvious (skewness: 1.14; standard error: 0.37) (Fig. 2).

Mean LDF value of the 19 pilot osteotomy sites of the 12 men was 29.74 PU, median 28.92, range 10.24-61.95, and standard deviation 15.28. Mean LDF value of the 22 pilot osteotomy sites of the 11 women was $22.39 \mathrm{PU}$, median 19.82, range 7.97-41.84, and standard deviation 8.64 PU (Table 1 and 2). The $P$-values of Student $t$-test and MannWhitney test, determining the gender effect, were 0.074 and 0.182 respectively. Levene test showed statistical significance for gender difference in standard deviations $(F=6.57, P=0.014)$. Spearman's rank correlation test of mean LDF values of the 23 patients did not show a relationship with patients' age $(R=-0.10, P=0.65)$ or history of edentulousness $(R=0.11, P=0.61)$. The number of patients in the 4 different resorption classes were too small for statistical analysis. The LDF recordings in the 4 classes were not very divergent mutually. 
Table 1. LDF values at the 41 pilot sites of 23 patients.

\begin{tabular}{|c|c|c|c|c|}
\hline Patient & Site 1 & Site 2 & Site 3 & Site 4 \\
\hline 1 & 30.62 & & & \\
\hline 2 & 11.44 & & & \\
\hline 3 & 18.61 & 32.45 & & \\
\hline 4 & 10.24 & 16.87 & & \\
\hline 5 & 41.84 & 31.17 & & \\
\hline 6 & 21.39 & & & \\
\hline 7 & 14.05 & 20.82 & & \\
\hline 8 & 17.12 & 17.52 & & \\
\hline 9 & 35.96 & 46.67 & & \\
\hline 10 & 16.79 & & & \\
\hline 11 & 26.04 & 30.03 & & \\
\hline 12 & 61.95 & & & \\
\hline 13 & 41.24 & 59.80 & & \\
\hline 14 & 16.48 & 28.92 & & \\
\hline 15 & 7.97 & 17.20 & & \\
\hline 16 & 19.29 & & & \\
\hline 17 & 38.30 & 22.05 & & \\
\hline 18 & 18.37 & 39.40 & & \\
\hline 19 & 29.73 & & & \\
\hline 20 & 17.62 & 26.68 & 19.49 & 10.84 \\
\hline 21 & 15.87 & 20.66 & & \\
\hline 22 & 16.00 & 20.15 & & \\
\hline 23 & 32.11 & 37.86 & & \\
\hline
\end{tabular}

Table 2. Means, medians, ranges, and standard deviations of LDF values (PU), separately for men and women.

\begin{tabular}{lcccccc}
\hline Gender & $\begin{array}{c}\text { Number of } \\
\text { Patients }\end{array}$ & $\begin{array}{c}\text { Number of } \\
\text { implant sites }\end{array}$ & Mean PU & Median & Range & $\begin{array}{c}\text { Standard } \\
\text { deviation }\end{array}$ \\
\hline Men & 12 & 19 & 29.74 & 28.92 & $10.24-61.95$ & 15.28 \\
Women & 11 & 22 & 22.39 & 19.82 & $7.97-41.84$ & 8.64 \\
Total & 23 & 41 & 25.80 & 20.82 & $7.97-61.95$ & 12.58 \\
\hline
\end{tabular}




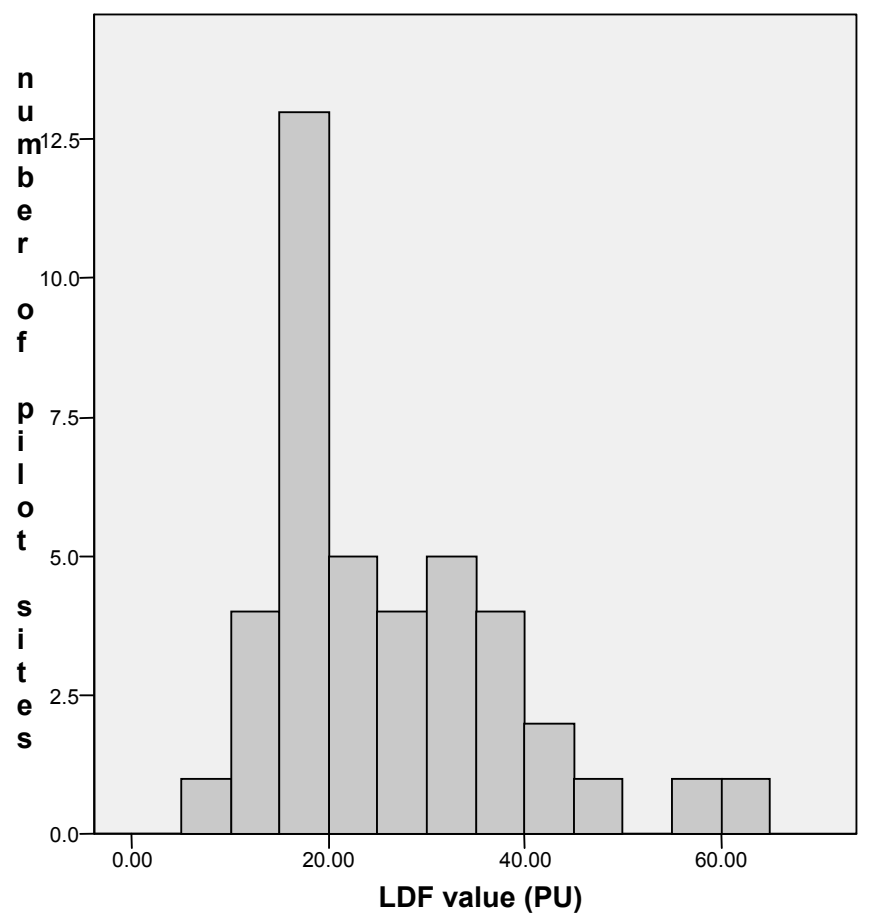

Figure 2. Graph of the distribution of LDF values (PU) of the 41 pilot sites

\subsection{Discussion}

Standardization of the laser diode device and the recording method is required for comparing results of various device users. The probes and the LDF equipment should be equal and the device should be calibrated according to the manufacturer's instructions. Applying the procedure used in this study, values recorded by various device users may provide a standard for human mandibular and maxillary bone vascularity.

This study is the first showing results of bone vascularity using LDF in humans. For statistical analysis, all implant sites in the patients were included. According to scientific statistical standards the method chosen may seem not permitted, because the rule of independence of measurements could be violated by including multiple recordings. Nevertheless, the statistical method was used because of several deliberate reasons. Important deliberations were the explorative and descriptive characteristics of this first human study into vascularity using LDF, and the site de- 
pendancy of vascularity. At multiple implant sites in one patient, LDF recordings may yield different LDF values. Consequently, there is no harmonious LDF value per jaw or per patient. However, the most important deliberation was that bone vascularity at an implant site was the expected factor influencing implant osseointegration and that an average LDF value does not represent the actual value at a certain implant site.

Student $t$-test and Mann-Whitney test did not show a gender effect on the LDF values recorded. In contrast with this result, Levene test revealed a statistical significance for gender difference in standard deviations. No explanation could be suggested for this apparent controversy. Possibly, future studies may elucidate this problem.

Because the LDF values of the 41 pilot osteotomy sites did not show linear relationship with patient's age or patient's history of edentulousness, at least in edentulous patients bone vascularity seems not to increase or decrease substantially due to the course of time.

LDF values distribution had a strong tendency to be positively skewed with a tail to the right and very few low values were present (Fig. 2). Therefore, interference with low LDF values, as likely will be recorded in irradiated patients, is not expected because of the rather sharp cut off at the lower border of the graphical curve (Fig. 2).

The results of a previous animal study demonstrated that comparison of LDF values between individual animals was possible, suggesting that also comparison of LDF values between humans is possible (Verdonck et al. 2007). A clinical trial with a group of irradiated and a group of nonirradiated patients needs to be performed in order to confirm the decreasing effect of irradiation on human bone vascularity.

Radiotherapy in head-and-neck cancer patients has been evolved from bilateral opposing radiation fields into intensity-modulated radiotherapy (IMRT) (Yao et al. 2005; Bortfeld, 2006). The multi-beam IMRT technique is used to ensure adequate radiation doses to target volumes and safe radiation doses to healthy tissues. IMRT used in the treatment of head and neck tumours may result in irradiation of the anterior mandibular bone, likely compromising bone vascularity, even if the tumour is not located in the anterior mouth area. Consequently, implant insertion at the anterior mandible will be at risk. In order to reduce the risk of osteoradionecrosis due to surgical intervention and to raise implant success rates in irradiated head-and-neck cancer patients, it would be very beneficial to define a minimal bone vascularity threshold allowing implant insertion safely. LDF may be helpful in this connection and may also dem- 
onstrate or confirm the effectiveness of hyperbaric oxygen therapy used for increasing bone vascularity. In addition, LDF may be also used in other conditions of (compromised) bone, for instance in vascularized and non-vascularized bone grafts.

One of the aims of the present study was providing standard data for bone vascularity in the human anterior mandible. Since these data are available as from now on, future studies should focus on bone quality more specifically, for instance on the influence of bone density on bone vascularity.

The study hypotheses that bone vascularity in the human anterior mandible can be assessed during implant insertion by LDF and that the recorded LDF values are providing standard data for bone vascularity in the human anterior mandible, were confirmed. However, studies in irradiated patients are needed for defining a vascularity threshold beyond which oral implants should not be inserted.

\section{Acknowledgement}

The authors are grateful to Biocomp Industries (Vught, The Netherlands) for generously putting their instruments and implants at disposal. 


\section{References}

Ahn, H., Johansson, K., Lundgren, O. \& Nilsson, G.E. (1987) In vivo evaluation of signal processors for laser Doppler tissue flowmeters. Medical and Biological Engineering and Computing 25: 207-211.

von Arx, T., Chappuis, V., Winzap-Kälin, C. \& Bornstein, M.M. (2007) Laser Doppler flowmetry for assessment of anterior mandibular teeth in conjunction with bone harvesting in the symphysis: a clinical pilot study. The International Journal of Oral \& Maxillofacial Implants 22: 383-389.

Beaulé, P.E., Campbell, P.A., Hoke, R. \& Dorey, F. (2006) Notching of the femoral neck during resurfacing arthroplasty of the hip: a vascular study. The Journal of Bone \& Joint Surgery $(\mathrm{Br})$ 88: 35-39.

Beaulé, P.E., Campbell, P. \& Shim, P. (2007) Femoral head blood flow during hip resurfacing. Clinical Orthopaedics and Related Research 456: 148-152.

Bollinger, A. \& Partsch, H. (2003) Christian Doppler is 200 years young. VASA 32: 225-233.

Bortfeld, T. (2006) IMRT: a review and preview. Physics in Medicine and Biology 51: R363R379.

Cawood, J.I. \& Stoelinga, P.J.W. (2006) International academy for oral and facial rehabilitation - Consensus Report. International Journal of Oral and Maxillofacial Surgery 35: 195-198.

Cawood, J.I. \& Howell, R.A. (1988) A classification of the edentulous jaws. International Journal of Oral and Maxillofacial Surgery 17: 232-236.

Donos, N., D'Aiuto, F., Retzepi, M. \& Tonetti, M. (2005) Evaluation of gingival blood flow by the use of laser Doppler flowmetry following periodontal surgery. A pilot study. Journal of Periodontal Research 40: 129-137.

Emshoff, R., Kranewitter, R., Brunold, S., Laimer, K. \& Norer, B. (2008) Characteristics of pulpal blood flow levels associated with non-segmented and segmented Le Fort I osteotomy. Oral Surgery, Oral Medicine, Oral Pathology, Oral Radiology, and Endodontology 105: 379-384.

Granström, G., Tjellström, A. \& Brånemark, P-I. (1999) Osseointegrated implants in irradiated bone: a case-controlled study using adjunctive hyperbaric oxygen therapy. Journal of Oral and Maxillofacial Surgery 57: 493-499.

Granström, G. (2005) Osseointegration in irradiated cancer patients: an analysis with respect to implant failures. Journal of Oral and Maxillofacial Surgery 63: 579-585.

Kocabalkan, E. \& Turgut, M. (2005) Variation in blood flow of supporting tissue during use of mandibular complete dentures with hard acrylic resin base and soft relining: A preliminary study. The International Journal of Prosthodontics 18: 210-213.

Marx, R.E. (1983) Osteoradionecrosis - A new concept of its pathophysiology. Journal of Oral and Maxillofacial Surgery 41: 351.

Mavropoulos, A., Brodin, P., Rösing, C.K., Aass, A.M. \& Aars, H. ( 2007) Gingival blood flow in periodontitis patients before and after periodontal surgery assessed in smokers and non- smokers. Journal of Periodontology 78: 1774-1782.

Michelson, G., Schmauss, B., Langhans, M.J., Harazny, J. \& Groh, M.J. (1996) Principle, validity, and reliability of scanning laser Doppler flowmetry. Journal of Glaucoma 5: 99105.

Murnaghan, M., Li, G. \& Marsh, D.R. (2006) Nonsteroidal anti-inflammatory drug-induced fracture nonumion: an inhibition of angiogenesis? The Journal of Bone \& Joint Surgery (Am) 88 (suppl. 3): 140-147. 
Nötzli, H.P., Swiontkowski, M.F., Thaxter, S.T., Carpenter, G.K. $3^{\text {rd }}$. \& Wyatt, R. (1989) Laser Doppler flowmetry for bone blood flow measurements: helium-neon laser light attenuation and depth of perfusion assessment. Journal of Orthopaedic Research 7: 413424.

Rajan, V., Varghese, B., van Leeuwen, T.G. \& Steenbergen, W. (2008) Review of methodological developments in laser Doppler flowmetry. Lasers in Medical Science 24: Epub ahead of print

Retzepi, M., Tonetti M. \& Donos,N. (2007) Comparison of gingival blood flow during healing of simplified papilla preservation and modified Widman flap surgery: a clinical trial using laser Doppler flowmetry. Journal of Clinical Periodontology 34: 903-911.

Røe, C., Damsgård, E. \& Knardahl, S. (2008) Reliability of bloodflux measurements from the upper trapezius muscle during muscle contractions. European Journal of Applied Physiology 102: 497-503.

Seike, K., Koda, K., Saito, N., Oda, K., Kosugi, C., Shimizu, K. \& Miyasaki, M. (2007) Laser Doppler assessment of the influence of division at the root of the inferior mesenteric artery on anstomotic blood flow in rectosigmoid cancer surgery. International Journal of Colorectal Disease 22: 689-697.

Singh, D.B., Stansby, G. \& Harrison, D.K. (2008) Assessment of oxygenation and perfusion in the tongue and oral mucosa by visible spectrophotometry and laser Doppler flowmetry in healthy subjects. Advances in Experimental Medicine and Biology 614: 227233.

Verdonck, H.W.D., Meijer, G.J., Laurin, T., Nieman, F.H.M., Stoll, C., Riediger, D., Stoelinga, P.J.W. \& de Baat, C. (2007) Assessment of vascularity in irradiated and nonirradiated maxillary and mandibular alveolar minipig bone using laser Doppler flowmetry. International Journal of Oral and Maxillofacial Implants 22: 774-778.

Visch, L.L., Van Waas, M.A.J., Schmitz, P.I.M. \& Levendag, P.C. (2002) A clinical evaluation of implants in irradiated oral cancer patients. Journal of Dental Research 81: 856859.

Weinlaender, M., Beumer, J. ${ }^{\text {rd }}$., Kenney, E.B., Lekovic, V., Holmes, R., Moy, P.K. \& Plenk, $\mathrm{H}$. Jr. Histomorphometric and fluorescence microscopic evaluation of interfacial bone healing around 3 different dental implants before and after radiation therapy. International Journal of Oral and Maxillofacial Implants 21: 212-224.

Yao, M., Dornfeld, K.J., Buatti, J.M., Skwarchuk, M., Tan, H., Nguyen, T., Wacha, J., Bayouth, J.E., Funk, G.F., Smith, R.B., Graham, S.M., Chang, K. \& Hoffman, H.T. (2005) Intensity-modulated radiation treatment for head-and-neck squamous cell carcinoma - the University of lowa experience. International Journal of Radiation Oncology ${ }^{*}$ Biology ${ }^{*}$ Physics 63: 410-421.

Yerit, K.G., Posch, M., Seemann, M., Hainich, S., Dortbudak, O., Turhani, D., Ozyuvaci, H, Watzinger, F. \& Ewers, R. (2006) Implant survival in mandibles of irradiated oral cancer patients. Clinical Oral Implants Research2 17: 337-344. 



\section{CHAPTER 6}

\section{Intensity-modulated radiation therapy for oropharyngeal cancer: Radiation dosage constraint at the anterior mandible}

Accepted for publication in Oral Oncology
H.W.D. Verdonck
J. de Jong
M. Granzier
F.H. Nieman
C. de Baat
P.J.W Stoelinga 


\subsection{Introduction}

New radiotherapy techniques, such as 3-dimensional conformal radiotherapy, intensity-modulated radiotherapy, and proton radiotherapy are allowing lower dosage and better dose distribution at non-target tissues and organs. ${ }^{1-5}$ Intensity-modulated radiotherapy (IMRT) uses modifications in the intensity of the photon-beam from a linear accelerator across the irradiated fields to enhance dose conformation in 3 dimensions. ${ }^{6}$ It can escalate the total dosage and fractional dose to target volumes and decrease the irradiation dosage of surrounding tissues and organs. The accurate target volume delineation of IMRT treating oropharyngeal cancer is essential for reducing recurrences and marginal failures and for improving local control. ${ }^{7}$

A large portion of patients with oropharyngeal cancer are suffering from disturbed anatomy and functional limitations due to tumour resection and primary or adjuvant radiotherapy. These patients can functionally and aesthetically benefit greatly from implant-supported prostheses. Oral implant treatment may increase their quality of life. ${ }^{8}$

Current data suggest that osseointegration is impaired in irradiated bone. ${ }^{9,10}$ Implant survival percentages in irradiated bone are known to be lower than in non-irradiated bone, particularly if the radiation dosage exceeds 50 Gray. ${ }^{11-14}$ Prospective studies have shown that irradiated bone becomes hypocellular and hypoxic and that the vascularity of irradiated bone is decreasing over time.$^{15}$ As a result, the continuous bone remodelling capacity will diminish, which explains the lower implant survival percentages.

Oropharyngeal cancers are currently often primarily treated by IMRT, irradiating the anterior mandible as well. Irradiation of the anterior mandible is inducing a risk of osteoradionecrosis or implant failure in this region. The irradiation dose distribution at the mandible is rarely considered and the risks are not always appreciated. ${ }^{16}$ Yet, IMRT has the potential to limit the irradiation dosage at the anterior mandible, because it allows detailed dose distribution, tailored at target tissues as well as at surrounding non-target tissues. ${ }^{17}$ This is important, since the anterior mandible is the location of preference when planning implants. Consequently, the risk of osteoradionecrosis can be reduced and the integration of oral implants can be improved. ${ }^{18}$

The aim of this study was to investigate the radiation dosage distribution at the anterior mandible and to study the feasibility of radiation dos- 
age constraint at the anterior mandible in oropharyngeal cancer patients primarily treated using IMRT. The study hypothesis was that adequate IMRT planning in oropharyngeal cancer patients is allowing for sufficiently low anterior mandibular bone radiation dosages to safely insert endosseous implants.

\subsection{Material and methods}

Ten randomly selected oropharyngeal cancer patients planned for primary radiotherapy using IMRT, were included. Tumour sites of the 10 patients were posterior pharyngeal wall (3), vallecula (2), base of the tongue (2), uvula (1), supraglottic area (1), and tonsillar region (1).

The dose distribution of the arranged fractionated radiation schedules at the anterior mandible of the 10 patients was analyzed. In each patient, planning positron emission tomography CT (Biograph True Point PETCT, Siemens Medical Solutions, Hoffman Estates, Illinois, USA) was performed with $3 \mathrm{~mm}$ slice thickness throughout the whole sequentially acquired region concerned, including the target and non-target regions. Patients were immobilized by a thermoplastic mask covering the head and shoulder region. Contouring and radiation planning were optimized using the CMS XiO treatment planning system, version 4.22 (CMS, Inc., St Louis, Missouri, USA). ${ }^{19}$ Radiation planning aimed at a tumour target dosage of $70 \mathrm{~Gy}$ in 35 fractions of $2 \mathrm{~Gy}$, considering a tolerance limit of dose for the parotid and submandibular salivary glands, the organs at risk of dysfunction after irradiation. Irradiation was delivered by $6-\mathrm{MeV}$ photon beams on a ONCOR Avant-Garde linear accelerator with the step and shoot multileaf collimator technique (Siemens Medical Solutions USA, Hoffman Estates, Illinois, USA). This technical solution resulted in 7-field arrangements ('class solution') in the patients. ${ }^{20}$

First, at 5 determined positions distributed over the anterior mandible, the appropriate radiation dosages were calculated according to the originally arranged fractionated radiation schedule. The determined mandibular positions were: (1) symphysis (midline), (2 and 3) $1.5 \mathrm{~cm}$ distal at each side of the midline, (4 and 5) at each mental foramen (Fig. 1). Second, for each patient an adjusted fractionated radiation schedule was established, taking into account that the anterior mandible needs protection against radiation-induced osteoradionecrosis. Considerations for the 


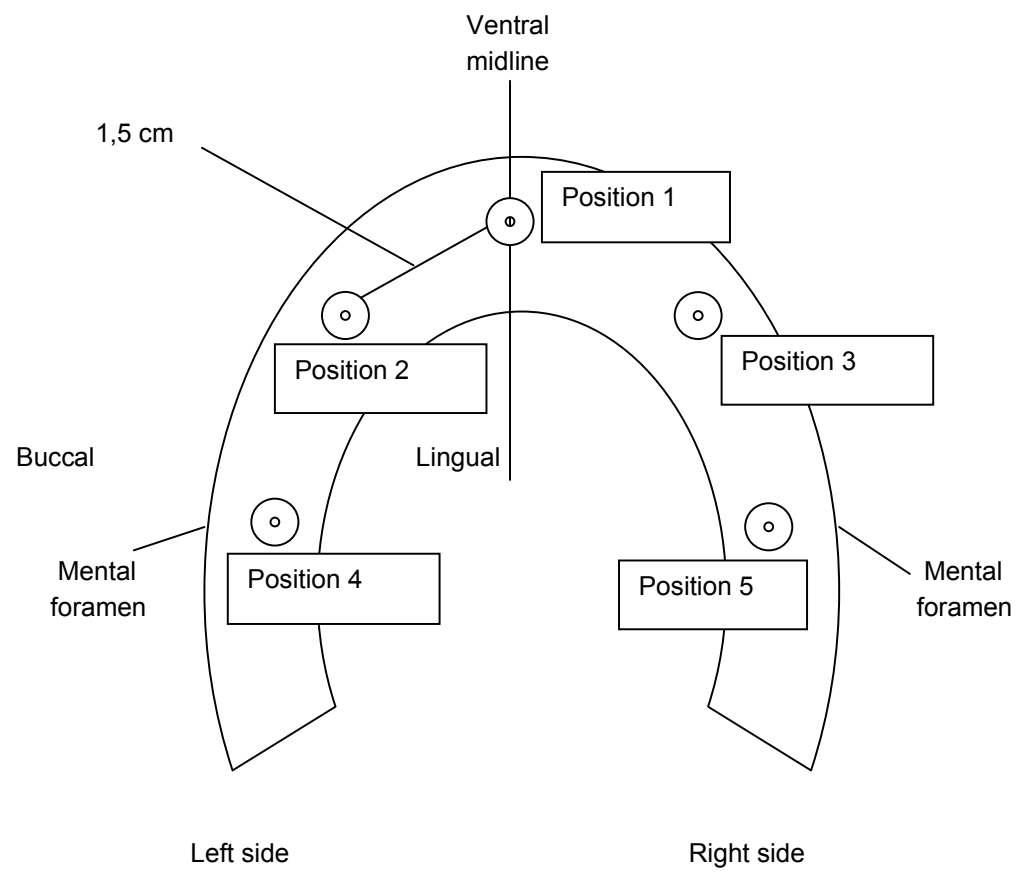

Fig. 1. Measuring points in the anterior mandible

adjusted fractionated radiation schedule were similar as those of the original fractionated radiation schedule, including a desired tumour target dosage of $70 \mathrm{~Gy}$ and the maximum mean local dosages for organs at risk. The aim was to maximally reduce the radiation dosage at the anterior mandible, preferably not exceeding $30 \mathrm{~Gy}$ in 35 fractions. According to the adjusted fractionated radiation schedule, appropriate radiation dosages at the 5 determined mandibular positions were calculated. All absolute radiation dosages were recalculated into dose equivalents in $2 \mathrm{~Gy}$ fractions using an $\alpha / \beta$ ratio of 3 to compensate effects of fraction size in normal tissue.

Means, medians, standard deviations, and ranges of radiation dosages (Gy) at the 5 determined mandibular positions were registered, both of the original and of the adjusted fractionated radiation schedules of the 10 patients. Differences between original and adjusted fractionated radiation schedules at each determined mandibular position were tested by Wilcoxon matched-pairs signed-ranks test as well as Wilcoxon exact test. 
Next, the average radiation dosages of the original and the adjusted fractionated radiation schedules over the 5 determined mandibular positions were calculated. Differences between average dosages were also tested by Wilcoxon matched-pairs signed-ranks test and Wilcoxon exact test. Radiation dosages at each of the 5 determined mandibular positions of the original and the adjusted fractionated radiation schedules were dichotomized: dosages lower than $30 \mathrm{~Gy}$ and equal or higher than $30 \mathrm{~Gy}$. For each determined mandibular position 2-by-2 cross tabulations of the dichotomized radiation dosages of the original and the adjusted fractionated radiation schedule were arranged. Finally, a 2-way within-factor repeated-measures ANOVA was performed for radiation dosages of the original and the adjusted fractionated radiation schedules at one hand and of the 5 determined mandibular positions at the other. If required, overall F-ratios degrees of freedom were corrected for deviations from sphericity within the variance-covariance matrix of repeated measurements by the more conservative Greenhouse-Geisser tests using epsilons. As the criterion for this correction statistical significance in Mauchly's $W$ test is used. A $P$-value of 0.05 was considered to be statistically significant. Data analysis was performed by SPSS-pc version 15.0 .

\subsection{Results}

Table 1 shows means, medians, standard deviations, and ranges of radiation dosages at the 5 determined mandibular positions, both of the original and the adjusted fractionated radiation schedule of the 10 patients.

Wilcoxon matched-pairs signed-ranks test and Wilcoxon exact test showed statistically significant differences between the mean radiation dosages of the original and the adjusted fractionated radiation schedules at each of the 5 determined mandibular positions (Table 2). Mean radiation dosages at the 5 determined mandibular positions of the original and the adjusted fractionated radiation schedule were $35.6 \pm 15.1$ (range 14.9 - 60.0) and 26.7 \pm 8.8 (range 14.9 - 41.5), respectively. The difference between these mean radiation dosages was statistically significant (Wilcoxon matched-pairs signed-ranks test: $P=0.012$; Wilcoxon exact test: $P=0.008$ ).

The 2-by-2 cross tabulations of the dichotomized radiation dosages ( $<30 \mathrm{~Gy}$; $\geq 30 \mathrm{~Gy}$ ) of the original and the adjusted fractionated radiation schedule at the 5 determined mandibular positions revealed a more pronounced radiation dosage constraint of the adjusted fractionated radiation 
schedule of dosages equal or higher than $30 \mathrm{~Gy}$, when compared with the original fractionated radiation schedule. The radiation dosage constraint between original and adjusted fractionated radiation schedule was $60 \%$ at position $1,50 \%$ at positions 2 and $4,33.3 \%$ at position 3 , and no constraint at position 5 (Table 3).

The 2-way within-factor repeated-measures ANOVA for radiation dosages of the original and the adjusted fractionated radiation schedules and of the 5 determined mandibular positions demonstrated a statistically significant difference between radiation dosages of the original and the adjusted fractionated radiation schedules over all positions $(F=8.15,1$ \& $9 \mathrm{df} ., P=0.019)$ and between the 5 determined mandibular positions over both schedules ( $F=5.28,4 \& 36 \mathrm{df}$., Greenhouse-Geisser corrected $P=0.030$ ).

Table 1. Means, medians, standard deviations, and ranges of radiation dosages at the 5 determined mandibular positions, both of the original and the adjusted fractionated radiation schedule of the 10 patients.

\begin{tabular}{llllll}
\hline $\begin{array}{l}\text { Mandibular } \\
\text { position }\end{array}$ & Radation schedule & Mean & Median & $\begin{array}{l}\text { Standard } \\
\text { deviation }\end{array}$ & Range \\
\hline 1 & Original & 31.5 & 30.9 & 14.9 & $11.7-57.7$ \\
1 & Adjusted & 23.0 & 21.8 & 8.3 & $11.7-39.4$ \\
2 & Original & 33.1 & 28.7 & 15.1 & $13.1-60.9$ \\
2 & Adjusted & 24.9 & 24.7 & 7.9 & $13.1-38.9$ \\
3 & Original & 37.4 & 41.0 & 16.1 & $15.4-59.1$ \\
3 & Adjusted & 27.6 & 26.1 & 10.2 & $15.4-44.8$ \\
4 & Original & 35.9 & 32.5 & 16.0 & $13.7-62.0$ \\
4 & Adjusted & 28.1 & 27.8 & 9.5 & $13.7-44.8$ \\
5 & Original & 39.8 & 41.4 & 17.0 & $19.1-59.6$ \\
5 & Adjusted & 31.3 & 33.7 & 11.2 & $18.7-48.5$ \\
\hline
\end{tabular}

Table 2. $P$-values of Wilcoxon matched-pairs signed-ranks test and Wilcoxon exact test for differences in mean radation dosages (Gy) of the original and adjusted fractionated radiation schedules at each determined mandibular position of the 10 patients.

\begin{tabular}{lll}
\hline Mandibular position & $\begin{array}{l}\text { Wilcoxon matched-paires } \\
\text { signed-ranks }\end{array}$ & Wilcoxon exact test \\
\hline 1 & 0.012 & 0.008 \\
2 & 0.021 & 0.023 \\
3 & 0.018 & 0.016 \\
4 & 0.036 & 0.039 \\
5 & 0.012 & 0.008 \\
\hline
\end{tabular}


Table 3. Cross tables of the original and adjusted fractionated radiation schedules at mandibular position 1-5.

\begin{tabular}{|c|c|c|c|}
\hline \multirow{2}{*}{$\begin{array}{l}\text { Original } \\
\text { Position } 1\end{array}$} & \multicolumn{2}{|c|}{ Adjusted } & \multirow[t]{2}{*}{ Total } \\
\hline & $<30 \mathrm{~Gy}$ & $\geq 30 \mathrm{~Gy}$ & \\
\hline$<30 \mathrm{~Gy}$ & $5(100 \%)$ & $0(0 \%)$ & $5(100 \%)$ \\
\hline$\geq 30 \mathrm{~Gy}$ & $3(60 \%)$ & $2(40 \%)$ & $5(100 \%)$ \\
\hline Total & 8 & 2 & 10 \\
\hline \multicolumn{4}{|l|}{ Position 2.} \\
\hline$<30 \mathrm{~Gy}$ & $6(100 \%)$ & $0(0 \%)$ & $6(100 \%)$ \\
\hline$\geq 30 G y$ & $2(50 \%)$ & $2(50 \%)$ & $4(100 \%)$ \\
\hline Total & 8 & 2 & 10 \\
\hline Position 3. & $<30 \mathrm{~Gy}$ & $\geq 30 \mathrm{~Gy}$ & \\
\hline$<30 \mathrm{~Gy}$ & $4(100 \%)$ & $0(0 \%)$ & $4(100 \%)$ \\
\hline$\geq 30 \mathrm{~Gy}$ & $2(33.3 \%)$ & $4(66.7 \%)$ & $6(100 \%)$ \\
\hline Total & 6 & 4 & 10 \\
\hline Position 4. & $<30 \mathrm{~Gy}$ & $\geq 30 \mathrm{~Gy}$ & \\
\hline$<30 \mathrm{~Gy}$ & $3(75 \%)$ & $1(25 \%)$ & $4(100 \%)$ \\
\hline$\geq 30 \mathrm{~Gy}$ & $3(50 \%)$ & $3(50 \%)$ & $6(100 \%)$ \\
\hline Total & 6 & 4 & 10 \\
\hline Position 5. & $<30 \mathrm{~Gy}$ & $\geq 30 \mathrm{~Gy}$ & \\
\hline$<30 \mathrm{~Gy}$ & $4(100)$ & $0(0 \%)$ & $4(100 \%)$ \\
\hline$\geq 30 \mathrm{~Gy}$ & $0(0 \%)$ & $6(100 \%)$ & $6(100 \%)$ \\
\hline Total & 4 & 6 & 10 \\
\hline
\end{tabular}

\subsection{Discussion}

The results of this study revealed a clinically relevant potential radiation dosage constraint at the anterior mandible when using IMRT. Yet, by the adjusted as well as by the original fractionated radiation schedule the target dosages of $70 \mathrm{~Gy}$ could be achieved. The results of this study also showed that by an adjusted fractionated radiation schedule, using IMRT, oropharyngeal cancers can be effectively irradiated. A concomitant advantage is that the anterior mandible is much less exposed to the risk of osteoradionecrosis or failure of dental implants. Thus, the hypothesis that adequate IMRT planning in oropharyngeal cancer patients is allowing sufficiently low anterior mandibular bone radiation dosages to safely insert implants is corroborated by our data. An important implication of this finding is, that a vast majority of oropharyngeal cancer patients, who have to undergo radiotherapy and who will need a prosthesis supported by oral 
implants inserted in the anterior mandible, may expect a successful prosthetic treatment.

The patients included all had an oropharyngeal tumour. Since IMRT is also commonly used for tumours in other locations the same principle may be applicable for patients with tumours of the tongue and floor of the mouth. Much, however, will depend on the seize of these tumours and their proximity to the mandible. Further research would be necessary to study its usefulness for these patients as well.

An additional advantage of IMRT is the possibility to also reduce the irradiation dosage to the salivary glands and even the pharyngeal constrictor muscles in selected patients. This in turn improves the quality of life of these patients, because hyposalivation and swallowing disorders can be prevented this way. ${ }^{21,22}$

The fractionated radiation schedules at different mandibular positions can also be used to determine the most favourable implant positions. Determining the most favourable implant positions is balancing the prosthetically preferred positions and the least irradiated positions. Consequently, it would be beneficial if the fractionated radiation schedules at different mandibular positions could be systematically integrated in software programmes of implant planning systems.

Several authors have pointed out the risks of osteoradionecrosis or implant failure due to high radiation dosage at the mandible. ${ }^{17,16,18}$ The feasibility of avoiding this unwanted side effect at intended implant recipient sites of the anterior mandible has, however, not been addressed as such. The outcome of this study is strongly encouraging to consider using IMRT because of the feasibility of dosage constraint at the anterior mandible when treating oropharyngeal cancer patients by irradiation.

As shown in a previous study, using laser Doppler flowmetry (LDF), bone vascularity is reduced in irradiated alveolar bone as compared to non-irradiated mandibular alveolar bone. ${ }^{23}$ LDF may ultimately be used to define the minimum vascularity needed to safely insert implants. A study in irradiated animals and human beings has already shown its potential for clinical use. ${ }^{24}$ The combination of IMRT and LDF may, in the foreseeable future, be the decisive tool to define whether implant insertion is warranted in a certain location and situation. For this to become clinically applicable, however, LDF data needs to be collected in patients treated with IRMT.

In conclusion, IMRT is a step forward in the treatment of oropharyngeal cancer, while at the same time the irradiation dosage at the anterior 
mandible can be constraint. The treatment of oropharyngeal cancer patients requires, however, close collaboration between radiation oncologist and prosthodontist, which implies the involvement of both disciplines from the beginning of the treatment. This will avoid frustrating experiences with loss of implants or even osteoradionecrosis at the anterior mandible, whilst it has the potential to improve the quality of life $(\mathrm{QOL})$ of the patients concerned.

Conflict of interest statement

The authors have no financial and personal relationships with other people or organizations that could inappropriately have influenced this work. 


\section{References}

1. Jereczek-Fossa BA, Zarowski A, Milani F, Orecchia R. Radiotherapy-induced ear toxicity. Cancer Treat Rev 2003;29(5):417-30.

2. Teo PM, Ma BB, Chan AT. Radiotherapy for nasopharyngeal carcinoma - transition from two-dimensional to three-dimensional methods. Radiother Oncol 2004;73(2):16372.

3. Mendenhall WM, Amdur RJ, Palta JR. Intensity-modulated radiotherapy in the standard management of head and neck cancer: promises and pitfalls. $J$ Clin Oncol 2006;24(17):2618-23.

4. Palm A, Johansson KA. A review of the impact of photon and proton external beam radiotherapy treatment modalities on the dose distribution in field and out-of-field; implications for the long-term morbidity of cancer survivors. Acta Oncol 2007; 46(4):462-73.

5. Olsen DR, Bruland OS, Frykholm G, Norderhaug IN. Proton therapy - a systematic review of clinical effectiveness. Radiother Oncol 2007; 83(2):123-32.

6. DeLaney TF, Trofimov AV, Engelsman M, Suit HD. Advanced-technology radiation therapy in the management of bone and soft tissue sarcomas. Cancer Control 2005;12(1):27-35.

7. Lee N, Puri DR, Blanco Al, Chao KS. Intensity-modulated radiation therapy in head and neck cancers: an update. Head Neck 2007;29(4):387-400.

8. Schoen PJ, Raghoebar GM, Bouma J, Reintsema H, Burlage FR, Roodenburg JLM, et al. Prosthodontic rehabilitation of oral function in head-neck cancer patients with dental implants placed simultaneously during ablative tumour surgery: an assessment of treatment outcomes and quality of life. Int J Oral Maxillofac Surg 2008; 37(1):8-16.

9. Cawood JI, Stoelinga PJW. International academy for oral and facial rehabilitation Consensus Report. Int J Oral Maxillofac Surg 2006; 35(3):195-8.

10. Weinlaender M, Beumer $\mathrm{J}^{3 \mathrm{rd}}$, Kenney EB, Lekovic V, Holmes R, Moy PK, et al. Histomorphometric and fluorescence microscopic evaluation of interfacial bone healing around 3 different dental implants before and after radiation therapy. Int $\mathrm{J}$ Oral Maxillofac Implants 2006; 21(2):212-24.

11. Granström G, Tjellström A, Brånemark P-I. Osseointegrated implants in irradiated bone: a case-controlled study using adjunctive hyperbaric oxygen therapy. $J$ Oral Maxillofac Surg 1999; 57(5):493-9.

12. Visch LL, Van Waas MAJ, Schmitz PIM, Levendag PC. A clinical evaluation of implants in irradiated oral cancer patients. J Dent Res 2002; 81(12):856-9.

13. Granström G. Osseointegration in irradiated cancer patients: an analysis with respect to implant failures. J Oral Maxillofac Surg 2005; 63(5):579-85.

14. Yerit KG, Posch M, Seemann M, Hainich S, Dortbudak O, Turhani D, et al. Implant survival in mandibles of irradiated oral cancer patients. Clin Oral Implants Res 20062;17(3): 337-44.

15. Marx RE. Osteoradionecrosis - A new concept of its pathophysiology. J Oral Maxillofac Surg 1983; 41(5):283-8

16 Parliament M, Alidrisi M, Munroe M, Wolfaardt J, Scrimger R, Thompson H, et al. Implications of radiation dosimetry of the mandible in patients with carcinomas of the oral cavity and nasopharynx treated with intensity modulated radiation therapy. Int $J$ Oral Maxillofac Surg 2005; 34(2):114-21. 
17. Kippenes H, Gavin PR, Parsaei H, Phillips MH, Cho PS, Leathers CW, et al. Spatial accuracy of fractionated IMRT delivery studies in canine paraspinal irradiation.Vet Radiol Ultrasound 2003; 44(3):360-6.

18. Ben-David MA, Diamante M, Radawski JD, Vineberg KA, Stroup C, Murdoch-Kinch CA, et al. Lack of osteoradionecrosis of the mandible after intensity-modulated radiotherapy for head and neck cancer: likely contributions of both dental care and improved dose distributions. Int J Radiat Oncol Biol Phys 2007; 68(2):396-402.

19. Lee N, Xia P, Fischbein NJ, Akazawa P, Akazawa C, Quivey JM. Intensity-modulated radiation therapy for head-and-neck cancer: the UCSF experience focusing on target volume delineation. Int J Radiat Oncol Biol Phys 2003; 57(1):49-60.

20. Nutting CM, Rowbottom CG, Cosgrove VP, Henk JM, Dearnaley DP, Robinson MH, et al. Optimalisation of radiotherapy for carcinoma of the parotid gland: a comparison of conventional, three-dimensional conformal, and intensity-modulated techniques. Radiother Oncol 2001; 60(2):163-72.

21. Eisbruch A, Levendag PC, Feng FY, Teguh D, Lyden T, Schmitz PI, et al. Can IMRT or brachytherapy reduce dysphagia associated with chemoradiotherapy of head and neck cancer? The Michigan and Rotterdam experiences. Int J Radiat Oncol Biol Phys 2007; 69 (2 Suppl): S40-2.

22. Shiboski CH, Hodgson TA, Ship JA, Schiødt M. Management of salivary hypofunction during and after radiotherapy. Oral Surg Oral Med Oral Pathol Oral Radiol Endod 2007; 103 (Suppl): S66.e1-19.

23. Verdonck HWD, Meijer GJ, Laurin T, Nieman FH, Stoll C, Riediger D, et al. Assessment of vascularity in irradiated and non-irradiated maxillary and mandibular alveolar minipig bone using laser Doppler flowmetry. Int J Oral Maxillofac Implants 2007; 22(5):774-8.

24. Verdonck HWD, Meijer GJ, Kessler P, Nieman FH, de Baat C, Stoelinga PJW. Assessment of bone vascularity in the anterior mandible using laser Doppler flowmetry. Clin Oral Impl Res 2008, accepted for publication. 



\section{CHAPTER 7}

Summary and address to the aims

Conclusions and future perspectives 


\section{Summary and address to the aims}

Chapter 1 sets out to introduce the concept of using dental implants to support or retain dental prostheses. This treatment has evolved since the early seventies and has achieved a high degree of sophistication. The current implants are made of titanium and are supposed to firmly integrate into the jaw bones. The placement of implants in the most favourable position has really been enhanced by using CT scans and implant planning programs. This method has improved the accuracy and predictability with regard to implant position.

Implant supported prostheses have also improved the means of rehabilitation for patients with head and neck tumours. Facial and oral prostheses can nowadays be fixed to implants placed in strategic positions. These implant retained oral and facial prostheses have resulted in a significant enhancement of quality of life when compared with the old adhesive-retained prostheses.

Patients with head and neck tumours, however, often undergo radiotherapy either as an adjunct after ablative surgery or as a single mode of treatment. Irradiation, however, causes hypoxity, hypocellularity and hypovascularity of the jaw bones, which in turn causes implant loss or may even cause osteoradionecrosis.

In order to reduce the risk of implant failure it would be advisable for clinicians to know to what degree the jaw bones are affected by the irradiation treatment. In principle there are four means of assessing the bone quality, including: assessment of bone mineral density ( BMD), assessment of implant stability and assessment of bone vascularity of intended implant recipient sites. It is also possible in certain circumstances, particularly when treating oro-pharyngeal tumours, to decrease the irradiation dose to a recipient site of implants. For this reason this study was set up to quantify the above mentioned parameters using quantative computed tomography ( QCT) to measure bone mineral density, resonance frequency analysis (RFA) for measuring implant stability and laser Doppler flowmetry (LDF) to measure bone vascularity.

Radiation oncologists currently use intensity modulated radiotherapy (IMRT) to treat oro-pharyngeal tumours. This method potentially puts the anterior mandible at risk if no measures are taken to reduce the irradiation dose in this part of the mandible. For this reason a study was carried out to measure the irradiation dose at the anterior mandible of patients 
with oro-pharyngeal cancer and to investigate the possible dose constraint at the anterior mandible.

Aims:

1. To measure vascularity in irradiated maxillary and mandibular alveolar bone compared to non-irradiated bone using LDF

2. To demonstrate that $L D F$ is a reproducible method for the assessment of alveolar bone vascularity.

Chapter 2 reports on an experimental animal study evaluating a method of measuring bone vascularity. The purpose of this animal study was to confirm that laser Doppler flowmetry (LDF) is a reproducible method for the assessment of maxillary and mandibular alveolar bone vascularity and that there is less vascularity in irradiated mandibular and maxillary bone compared to non-irradiated bone. All maxillary and mandibular premolars and molars of 6 Göttingen minipigs were extracted. After a 3month healing period, 3 minipigs received irradiation at a total dose of 24 Gy. Three months after irradiation, 5 holes were drilled in the residual alveolar ridge of each edentulous site in each minipig. Local microvascular blood flow around all 120 holes was recorded by LDF prior to implant placement. In one irradiated and one non-irradiated minipig, an additional hole was drilled in a right maxillary site to enable repeated LDF recordings. The alveolar bone appeared less vascularized in irradiated than in nonirradiated minipigs. The effect of radiation appeared more pronounced in the mandible than in the maxilla. LDF was demonstrated to be a reproducible method for assessing alveolar bone vascularity. The hypotheses regarding LDF and vascularity were supported.

Aim:

To measure stability of implants placed in irradiated and non-irradiated bone, at placement and during osseointegration.

In chapter 3 the same minipigs were used as in chapter 2 to measure stability of implants placed in both irradiated and non-irradiated bone. 
The study was designed to monitor and test implant stability immediately after implant placement and during osseointegration in minipig alveolar bone.

After assessment of bone vascularity by laser Doppler flowmetry recordings, carried out in the initial holes, a total of 120 implants were placed in the six minipigs. Subsequently, and at 8,16 , and 24 weeks after implant placement, implant stability was recorded by resonance frequency analysis (RFA). RFA values were expressed as an implant stability quotient (ISQ).

$I S Q$ values recorded immediately after implant placement showed no differences between irradiated and non-irradiated minipigs. Repeated measurements at the four recording moments showed a decrease of ISQ values in all minipigs, being more pronounced in irradiated bone, when compared with non-irradiated bone. The results at the third and fourth recording moments showed a stabilization or even a slight increase of $I S Q$ values.

The results document the negative effect of irradiation on bone vascularity and hence on the stability of the implants.

Aim:

To measure bone mineral density $(B M D)$ in irradiated and non-irradiated bone by quantative computer tomography (QCT)

The same animals as used in chapter 2 and 3 were used in chapter 4 to measure bone mineral density using quantitative computer tomography. The objective of this part of the study was to analyse the effect of irradiation on bone mineral density (BMD).

At 3 months after irradiation, quantitative computed tomography (QCT) was performed. As a reference, a calibration bone phantom with pre-determined BMD was attached to the head of the minipigs. The QCT data were imported into a software program to calculate the BMD of the alveolar bone and the calibration bone phantom. In order to compare $B M D$ values of individual minipigs, the so called bone mineral density quotient (BMDQ) was created, dividing the BMD value of the alveolar bone by the BMD value of the calibration bone phantom.

Mean BMDQ values appeared to be higher in irradiated than in nonirradiated minipigs. However, the difference was not significant. In both irradiated and non-irradiated minipigs, the average mandibular BMDQ 
values were statistically significantly higher than the average maxillary BMDQ values. It could be concluded that, 3 months after irradiation, the BMD of irradiated alveolar minipig bone was increased, when compared with non-irradiated alveolar minipig bone. This increase, however was not statistically significant.

Aim:

To measure vascularity in the human anterior mandible by $L D F$, to define a human standard for vascularity in this part of the mandible

In irradiated bone, a method of measuring vascularity of the intended implant site would be of importance as to assess the quality of the recipient bone. This could potentially be helpful in defining a threshold beyond which implants cannot be used anymore. At present, assessing bone vascularity, using laser Doppler flowmetry (LDF), is possible. Chapter $\mathbf{5}$ describes the clinical study in which twenty-three randomly selected nonirradiated edentulous patients scheduled for treatment with oral implants in the anterior mandible were incorporated. The hypotheses of this study were that bone vascularity in the human anterior mandible can be assessed during implant insertion by LDF and that the recorded LDF values are providing standard data for bone vascularity in the human anterior mandible. There were 12 men and 11 women. The duration of edentulousness and the resorption pattern of the residual alveolar ridges were registered. In the pilot holes of the planned implant insertion the bone vascularity was measured, using LDF and expressed in perfusion units (PU). The statistical distribution and characteristics of the LDF values were defined separately for men and women.

A total of 41 pilot sites were recorded with a mean LDF value of 25.80 PU. No obvious gender differences were found and LDF values did not show a relationship with patient's age or duration of edentulousness. The hypotheses that bone vascularity in the human anterior mandible can be assessed during implant insertion by LDF and that the recorded LDF values are providing standard data for bone vascularity in the human anterior mandible, were confirmed. 
Aim:

To study irradiation dose distribution and possible dose constraint at the anterior mandible

New techniques in radiotherapy such as intensity-modulated radiotherapy (IMRT) are allowing lower dosage and better dose distribution at nontarget tissues and organs. This may have great implications when planning for implant insertion after irradiation treatment. This is particularly the case when primarily treating oro-pharyngeal tumours. Implant survival percentages in irradiated bone are known to be lower than in nonirradiated bone, particularly if the irradiation dose exceeds 50 Gray. Chapter 6 describes the study in which the possibility of dose constraint at the anterior mandible is investigated. The hypothesis of this study is that adequate planning of IMRT allows for sufficient dose reduction at the anterior mandible, the most used implant site, allowing for save implant insertion after irradiation treatment. Ten randomly selected patients with oro-pharyngeal cancer treated by IMRT were included in this study. First, at five positions divided over the anterior mandible, the applied radiation doses were calculated in the original treatment plan of the ten patients. Second, for each patient a new treatment plan was made, taking into account that the anterior mandible was designated as a critical area to protect. The criteria for the new treatment plan were the same as for the first plan, implying that the tumour target dose of $70 \mathrm{~Gy}$ and the maximum mean doses of the organs at risk had to be respected. The data reveal a considerable, statistical significant, irradiation dose reduction in the anterior mandible. As a result of the outcome of this study it is strongly advised to consider possible dose constraint in the anterior mandible when planning irradiation on oro-pharyngeal cancer patients using IMRT.

\section{Conclusions and future perspectives}

Patients who have undergone radiation therapy in the head and neck area are seriously at risk when implants have to be placed in the jaws to support a prosthesis. This is particularly true when the irradiation dose has exceeded $50 \mathrm{~Gy}$. This risk implies implant loss because of failure to integrate in the bone and may even lead to osteo-radionecrosis. Implants are usually necessary to provide these patients with reasonably stable 
prostheses, that contribute to their well being, as is borne out in various studies that measure their quality of life after this treatment. For the maxillofacial prosthodontist this presents a dilemma, because he or she is generally not aware whether the dose received has caused an impairment of the vascularisation of the bone that precludes the successful insertion and/or survival of implants. This is especially true for the area where implants are usually wanted i.c. the anterior mandible. Till present, no means was available to assess the quality of the receiving bone other than the information about the dose received. This information, however, does not always relate to the chance of success or failure of the implants. The only knowledge currently available points towards an increased risk when implants are placed in irradiated jaws with a dose of more that 4050 Gy.

Based on the results of this study it may be concluded that the best and clinically most suitable instrument to measure the influence of irradiation on bone vascularity is LDF. The measurement of bone mineral density and implant stability did support the notion that irradiation has a detrimental effect on the integration of implants in the bone, but these parameters are less capable to assess beforehand whether the bone is suitable to receive implants, without running the risk of implant loss. LDF certainly does have this capacity and might turn out to be the only parameter to assess the vascularity of the potential recipient bone. When using LDF to measure bone vascularity, however, standardization of instrument and measuring method is required in order to be able to compare results between different laser Doppler measurements. Probes and equipment parameters must be consistent, and the instrument must be calibrated according to the manufacturer's instructions.

This study paved the way for further research in this field, which will mainly have to consist of building up a data base of LDF measurements on irradiated patients and non-irradiated patients in different areas of the jaws. This way a link can be made between objectively determined vascularity, irradiation dose at the planned implant site and implant survival. Ultimately, when enough data are collected, it should be possible to determine whether implants can be inserted in patients that have undergone irradiation therapy. This would imply a major step forwards in the planning of prosthetic rehabilitation of occlusion and articulation of these severely handicapped patients. 
The results of this study give rise to the following considerations. In order to place implants in irradiated bone it is desirable to estimate the chances of implant survival. This is of paramount importance, since successful implant support for prosthetic devices, for a large part, defines the quality of life of these patients. It also avoids frustrating experiences for both the patient and the maxillofacial prosthodontist.

These chances may be improved by two measures that have a different background.

First, when planning on primary irradiation of oro-pharyngeal cancer it would be recommendable to involve the maxillofacial prosthodontist in the planning of the post- radiation treatment to restore oral function. When implant placement is foreseen for this treatment, the radiotherapist should be made aware of the preferred implant sites as to try to constrain the irradiation dose in these areas, when using IMRT. This would require close cooperation between these two specialists, because the irradiation planning data should also be used for the planning of the implant positions.

Second, when implants are planned to be inserted in patients who underwent irradiation therapy, LDF measurements are to be recommended via probe holes created at the preferred implant sites. This policy serves two purposes. Firstly, it gives the clinician an objective impression on the vascularity status of the recipient bone, that he can correlate to the failure or success of the implant. This is particularly important since as yet not enough historical data are available to define the critical threshold value for successful implant insertion in certain areas of the jaws. Secondly, by accumulating these LDF data, expertise will be build up to eventually be able to define the thresholds in every area of the jaws.

In the near future, when enough data are collected, clinicians will be able to exactly define the acceptable vascularity threshold in all areas of the jaws to assure safe implant insertion. That will change the protocols from trial and error into evidence based practice. 


\section{CHAPTER 8}

Samenvatting en evaluatie van de doelstellingen Conclusies en toekomstperspectief 


\section{Samenvatting en evaluatie van de doelstellingen}

In hoofdstuk 1 wordt in het kort de evolutie van het gebruik van orale implantaten beschreven. Deze implantaten zijn gemaakt van titanium en hun oppervlak is tegenwoordig voorzien van een coating waardoor ze gemakkelijk integreren in bot. Het gebruik van implantaten heeft een ware revolutie teweeggebracht in de tandheelkunde en vooral in de wijze waarop tegenwoordig gebitsprothesen op de implantaten kunnen worden bevestigd. Het bepalen van de beste positie van implantaten in het kaakbot wordt mogelijk gemaakt door gebruik te maken van een CT-scan, waarvan de data worden gebruikt in een software-programma voor implantaatplanning. Deze methode heeft de nauwkeurigheid van het plaatsen van implantaten sterk vergroot en daarmee ook de voorspelbaarheid van het resultaat.

Implantaatgedragen prothetische constructies hebben ook de mogelijkheden vergroot om patiënten te rehabiliteren bij wie een resectie van een deel van de kaak of van het aangezicht is uitgevoerd in verband met een maligne tumor. Aangezichts- en gebitsprothesen kunnen tegenwoordig verankerd worden op implantaten die zijn geïntegreerd in het bot. Dit heeft geleid tot een bewezen, aanzienlijke verbetering van de levenskwaliteit van deze uitermate gemutileerde en in orale functie beperkte mensen. Patiënten met maligne tumoren in de mond, de kaak of het aangezicht krijgen vaak aanvullend radiotherapie of krijgen zelfs primair radiotherapie. Door de radiotherapie wordt de kwaliteit van het bot ernstig aangetast omdat er een verminderde vascularisatie ontstaat en het aantal vitale cellen vermindert. Dit kan leiden tot osteoradionecrose waarbij delen van het bot spontaan worden afgestoten. Een gering trauma, waaronder het plaatsen van een implantaat, kan deze osteoradionecrose initiëren. In het algemeen integreren implantaten slecht in bot dat bestraald is met een dosis boven 40-50 Gray.

Ten einde het risico van het verlies van implantaten te verkleinen, zou het nuttig zijn om te kunnen bepalen hoe groot de mate van de door radiotherapie veroorzaakte schade is. In principe zijn er 3 methoden om de botkwaliteit te bepalen: het meten van de botdichtheid, het meten van de stabiliteit van een implantaat en het meten van de vascularisatie van het bot. Daarom was het de opzet van dit onderzoek deze parameters te kwantificeren met behulp van achtereenvolgens kwantitatieve computertomografie ('quantitative computer tomography'; QCT), resonantiefrequentieanalyse (RFA) en laser Doppler flowmetrie (LDF). 
Om orofarynxtumoren te behandelen, gebruiken radiotherapeuten steeds vaker 'intensity modulated radiotherapy' (IMRT). Dit brengt met zich mee dat het voorste deel van de onderkaak vaak een grote dosis straling krijgt, tenzij er beschermende maatregelen genomen kunnen worden. Om deze reden werd ook een onderzoek uitgevoerd bij een aantal patiënten met een maligne orofarynxtumor. Hierbij werd de bestralingsdosis in dit gebied gemeten met het doel te onderzoeken of dosisreductie mogelijk zou zijn.

\section{Doelen:}

1 Het meten van de vascularisatie in zowel bestraald als niet-bestraald bot van de boven- en de onderkaak met behulp van LDF.

2 Aantonen dat LDF een reproduceerbare methode is om de vascularisatie van kaakbot te meten.

In hoofdstuk 2 wordt een experimenteel onderzoek beschreven ter evaluatie van een methode om de vascularisatie van kaakbot te meten. Het doel was te bevestigen dat LDF een reproduceerbare meetmethode is en vast te stellen of de vascularisatie in bestraald bot minder is dan in nietbestraald bot.

Bij 6 Göttinger minivarkens werden zowel in de boven- als in de onderkaak alle kiezen verwijderd. Na een genezingsperiode van 3 maanden werden de boven- en de onderkaken van 3 minivarkens bestraald met een totale dosis van $24 \mathrm{~Gy}$. Drie maanden na de bestraling werden per tandeloze kaakhelft bij ieder varken 5 voorlopige implantaatschachten geprepareerd met behulp van een boor van het Biocomp implantaatsysteem. In elk van deze in totaal 120 voorlopige implantaatschachten werd met LDF de vascularisatie van het omringende bot gemeten. In 1 bestraald en 1 niet-bestraald minivarken werd in de rechterbovenkaak een extra schacht geprepareerd om hierin herhaalde metingen te kunnen verrichten. De vascularisatie van het bestraalde bot bleek significant minder te zijn dan die van het niet-bestraalde bot. Dit verschil bleek groter in de onderkaak dan in de bovenkaak. Aangetoond werd dat LDF een reproduceerbare methode is om de vascularisatie van kaakbot te meten. De hypothesen met betrekking tot vascularisatie van kaakbot en LDF werden bevestigd. 
Doel:

Het meten van de stabiliteit van implantaten in bestraald en niet-bestraald bot, zowel ten tijde van het plaatsen van de implantaten als gedurende de periode van osseoïntegratie.

In hoofdstuk 3 werden dezelfde minivarkens gebruikt als beschreven in hoofdstuk 2, nu om de stabiliteit van implantaten te meten in bestraald en niet-bestraald bot bij plaatsing van de implantaten en gedurende de daaropvolgende maanden na de initiële integratie in het kaakbot.

$\mathrm{Na}$ het meten van de vascularisatie (hoofdstuk 2) werden bij de 6 minivarkens in de voorlopige implantaatschachten in totaal 120 implantaten geplaatst en direct aansluitend werd de primaire stabiliteit gemeten met RFA. Deze metingen werden 8, 16 en 24 weken daarna herhaald. De stabiliteit van de implantaten werd uitgedrukt in het implantaatstabiliteitquotiënt ('implant stability quotient'; ISQ). De ISQ-waarden op het moment van plaatsing van de implantaten verschilden niet tussen bestraalde en niet-bestraalde minivarkens. De herhaalde metingen toonden echter bij de implantaten van alle minivarkens een vermindering van de stabiliteit aan. Deze vermindering was bij de bestraalde minivarkens significant groter dan bij de niet-bestraalde minivarkens. De resultaten van de derde en vierde meting lieten een stabilisatie of zelfs geringe stijging van de ISQ-waarden zien. De resultaten bevestigden het negatieve effect van radiotherapie op de vascularisatie van kaakbot met als gevolg verlies van stabiliteit van implantaten.

Doel:

Het meten van de botdichtheid ('bone mineral density'; BMD) in bestraald en niet-bestraald bot met behulp van QCT.

In hoofdstuk 4 werd gebruik gemaakt van dezelfde minivarkens als in de hoofdstukken 2 en 3, maar nu om de BMD te meten met QCT.

Drie maanden na de bestraling werd van alle minivarkens een CTscan gemaakt waarbij als referentie een fantoom met bekende BMD, dat was bevestigd aan de kop van de minivarkens, werd meegescand. De QCT-data werden in een softwareprogramma ingevoerd om de BMD van het kaakbot en het fantoom te berekenen. Om de BMD-waarden van de individuele minivarkens te kunnen vergelijken, werd het botdichtheids- 
quotiënt ('bone mineral density quotient', BMDQ) berekend door de BMDwaarde van het bot te delen door de BMD-waarde van het fantoom. De gemidelde BMDQ-waarden bleken hoger te zijn in bestraald dan in nietbestraald bot. Het verschil was echter niet significant. Wel waren zowel in bestraald als in niet-bestraald bot de gemiddelde BMDQ-waarden in de onderkaak significant groter dan in de bovenkaak.

De conclusie was dat 3 maanden na bestraling de botdichtheid van het kaakbot van bestraalde minivarkens groter was dan van nietbestraalde minivarkens. Dit verschil was echter statistisch niet significant.

Doel:

Met behulp van LDF de vascularisatie meten in het voorste deel van de onderkaak van tandeloze patiënten om te komen tot een standaard voor de vascularisatie van dit deel van de onderkaak.

Een methode om in bestraald bot de vascularisatie ter plaatse van geplande implantaatposities te kunnen meten, zou van belang kunnen zijn om de kwaliteit van dit bot vast te stellen. Hiermee zou mogelijk een drempelwaarde vastgelegd kunnen waaronder implanteren als te risicovol moet worden beschouwd.

In hoofdstuk 5 wordt een klinisch onderzoek beschreven onder 23 nietbestraalde tandeloze patiënten die een indicatie voor implantatie in het voorste deel van de onderkaak hadden. De hypothesen van dit onderzoek waren dat het mogelijk is om de vascularisatie van humaan kaakbot te meten met LDF en dat de gemeten gemiddelde waarde een standaard vormt voor de vascularisatie van het voorste deel van de onderkaak. Het betrof 12 mannen en 11 vrouwen. De duur van hun tandeloosheid en het resorptiepatroon van hun kaak werden vastgelegd. In de met een boor geprepareerde voorlopige implantaatschachten werd de vascularisatie van het omringende bot gemeten met behulp van LDF. De meetwaarden werden uitgedrukt in perfusie-eenheden ('perfusion units'; PU). In totaal werden op 41 implantaatposities metingen verricht met als resultaat een gemiddelde waarde van 25,80 PU. Er werden geen geslachtsverschillen gezien en er bleek ook geen verband te bestaan met de leeftijd van de patiënten, de duur van de tandeloosheid en het resorptiepatroon van de kaak. 
De hypothesen dat de vascularisatie van het voorste deel van de onderkaak met LDF gemeten kan worden en dat de gemeten gemiddelde waarde een standaard vormt voor de vascularisatie van dit deel van de onderkaak, werden bevestigd.

Doel:

Het meten van de dosisverdeling en mogelijke dosisreductie in het voorste deel van de onderkaak.

Nieuwe bestralingstechnieken, zoals IMRT, maken een kleinere dosis en betere dosisverdeling buiten het doelgebied mogelijk. Dit kan grote gevolgen hebben voor het plaatsen van implantaten na radiotherapie, in het bijzonder bij de primaire radiotherapie van orofarynxtumoren. Het is immers bekend dat het overlevingspercentage van implantaten in bestraald bot lager is dan in niet-bestraald bot.

In hoofdstuk 6 worden de resultaten weergegeven van een onderzoek waarbij de haalbaarheid van dosisreductie bij radiotherapie in het voorste deel van de onderkaak werd onderzocht. De hypothese was dat IMRT een dosisreductie in het voorste deel van de onderkaak, het gebied waarin de meeste implantaten geplaatst worden, mogelijk maakt.

Bij 10 patiënten, die met IMRT voor een orofarynxtumor waren behandeld, werden op 5 vastgestelde punten in het voorste deel van de onderkaak de gegeven doses berekend. Vervolgens werd voor iedere patiënt een nieuw bestralingsplan gemaakt waarbij nu ook het voorste deel van de onderkaak werd ontzien met betrekking tot de te ontvangen bestralingsdosis. De doelstelling van het nieuwe plan was hetzelfde als van het originele plan, dat wil zeggen een adequate bestralingsdosis voor het gebied van de tumor, maar maximale reductie voor het voorste deel van de onderkaak. De gegevens met IMRT laten een significante dosisreductie zien in het voorste deel van de onderkaak ten opzichte van het eerste plan. Dit resultaat leidt tot het advies om, indien mogelijk, met IMRT een dosisreductie te bewerkstelligen bij patiënten die na radiotherapie in aanmerking komen voor het plaatsen van implantaten in het voorste deel van de onderkaak. 


\section{Conclusies en toekomstperspectief}

Het plaatsen van implantaten in bestraald bot bij patiënten met maligne tumoren in het hoofd-halsgebied houdt een zeker risico in. Het gaat daarbij om verlies van implantaten ten gevolge van het falen van de osseoïntegratie en om het ontstaan van osteoradionecrose. Verankering van gebitsprothesen op implantaten is bij deze patiënten vaak noodzakelijk voor een goed herstel van de functie. Bovendien, zoals uit meerdere onderzoeken gebleken is, leidt deze verankering tot een verbetering van de levenskwaliteit.Voor een tandarts-maxillofaciaalprothetist bestaat echter een dilemma omdat niet duidelijk is in hoeverre de vascularisatie van het kaakbot door de bestraling verminderd is. Een verminderde vascularisatie kan de osseoïntegratie van de implantaten verhinderen, met als gevolg verlies van implantaten of zelfs osteoradionecrose veroorzaken. Dit geldt vooral voor het voorste deel van de onderkaak omdat in dit gebied de implantaten meestal geplaatst worden. Tot nu toe was er geen middel voorhanden om een inschatting te maken van de botkwaliteit, behalve de informatie over de toegepaste hoeveelheid straling. Deze informatie is op zich onvoldoende om het succes of falen van de implantaten te bepalen. Het is alleen bekend dat hoe groter de dosis is, hoe groter het risico op verlies van de implantaten is. Dit speelt vooral een rol als de dosis boven 40-50 Gy komt.

Op basis van de resultaten van dit onderzoek mag geconcludeerd worden dat LDF een goed en ook klinisch geschikt instrument is om de invloed van radiotherapie op de vascularisatie van bot te meten. De metingen van de BMD en het ISQ ondersteunen de bevinding dat radiotherapie een negatief effect heeft op de osseoïntegratie van implantaten, maar deze parameters zijn minder geschikt om op voorhand te bepalen of het plaatsen van implantaten verantwoord is. LDF is hiervoor wel geschikt en is mogelijk het enige middel om de vascularisatie van kaakbot te meten. Hiervoor is het echter nodig om een standaardisering van instrument en meetmethode te gebruiken. De sondes van de LDFmeetinstrumenten moeten gelijk zijn en een LDF-meetinstrument moet volgens de aanwijzingen van de leverancier gekalibreerd zijn.

Dit onderzoek heeft de weg geëffend voor verder onderzoek op dit gebied. Hierbij zal het vooral gaan om het aanleggen van een "database" van LDF-metingen bij bestraalde en niet-bestraalde patiënten in verschillende gebieden van de onder- en de bovenkaak. Op deze manier kan een verband gelegd worden tussen objectief gemeten botvascularisatie, 
bestralingsdosis in het implantaatgebied en de kans op succesvol implanteren. Als genoeg data verzameld zijn, moet het uiteindelijk mogelijk zijn vast te stellen of het plaatsen van implantaten bij een bestraalde patiënt mogelijk en verantwoord is. Dit zou een grote stap vooruit zijn in het plannen van de prothetische behandeling van deze ernstig gecompromitteerde patiënten.

De resultaten van dit onderzoek geven aanleiding tot twee overwegingen.

Ten eerste is het aan te bevelen als radiotherapie gepland wordt, rekening te houden met de planning van de prothetische behandeling na de radiotherapie. Als het behandelplan voorziet in het plaatsen van implantaten dan dient de radiotherapeut geïnformeerd te worden over de lokatie van de toekomstige implantaten teneinde de bestralingsdoses in deze gebieden zoveel mogelijk te beperken. De huidige IMRT-techniek maakt een dergelijke dosisreductie in de meeste gevallen mogelijk. Een nauwe samenwerking tussen radiotherapeut en tandarts-maxillofaciaalprothetist is daarom een vereiste, mede ook om na de radiotherapie de bestralingsdata te kunnen betrekken bij het bepalen van de meest geschikte implantaatposities.

In de tweede plaats zou voorafgaand aan de plaatsing van de implantaten met behulp van LDF de mate van vascularisatie gemeten kunnen worden. Dat geeft niet alleen inzicht in de vascularisatie ter plaatse, maar levert uiteindelijk de informatie om de drempelwaarden te kunnen bepalen waaronder het plaatsen van implantaten moet worden afgeraden. Dit zal uiteindelijk kunnen leiden tot wetenschappelijk gefundeerde beslissingen met betrekking tot de rehabilitatie van patiënten met maligne tumoren in het hoofd-halsgebied. 


\section{Dankwoord}

Hooggeleerde promotoren Stoelinga en de Baat, beste Paul en beste Cees. Het was een genoegen om onder jullie bezielende leiding dit onderzoek te mogen doen. Ik ben jullie ongelooflijk veel dank verschuldigd en ben blij dat onze wegen elkaar kruisten.

Cees, jouw steun in de beginperiode was essentieel om te kunnen starten en jouw grondige en snelle revisies tijdens het verdere verloop van het project hebben mij veel geleerd.

Paul, jouw doortastende optreden had ik nodig om dit project tot een goed einde te brengen. Ook was het een eer om als tandarts-mfp met je te mogen samenwerken tijdens je periode als afdelingshoofd in Maastricht. Je hebt mij alle ruimte gegeven om mij verder te ontwikkelen.

Beste Gert Meijer, co-promotor, vele malen heb ik een beroep op je mogen doen als bij mij de twijfel over de juistheid van mijn handelen toesloeg. Jouw immer warme belangstelling heb ik altijd zeer op prijs gesteld.

Fred Nieman, met zeer veel geduld heb jij mij geholpen bij het verwerken van alle data. Mijn hartelijke dank hiervoor.

Thorsten Laurin, zonder jouw niet aflatende inzet tijdens het dieronderzoek was het zeker niet goed gegaan. Het was een heel bijzondere ervaring die ik niet snel zal vergeten.

Jos de Jong, hartelijk dank voor je medewerking en meedenken bij het opzetten van het IMRTonderzoek.

Marlies Granzier, zonder jouw grote inzet was het IMRTonderzoek zeker niet zo vlot verlopen. Mijn dank hiervoor.

Leo Visch, ik ben je nog steeds dankbaar dat je mij in het verleden de mogelijkheid hebt gegeven om door jou als tandarts-mfp in de Daniël den Hoed kliniek opgeleid te worden. Je hebt toen al geprobeerd mij te interesseren voor onderzoek bij patiënten met hoofd-halstumoren.

Zonder jou, Boudewijn Engel, was het nooit zover gekomen. Jij hebt mij in het verleden de leeuwen en beren van de weg leren halen zodat het mogelijk werd om de juiste keuze te maken.

Rita, Nicole en Ingrid, dank voor jullie niet aflatende steun en begrip. 



\section{Curriculum Vitae}

Henricus Wilhelmus Dymphena Verdonck was born on April $28^{\text {th }} 1955$ in Valkenswaard, the Netherlands. He attended highschool (Gymnasium ß) at the Hertog Jan College in Valkenswaard and graduated in 1973. He studied dentistry at the Radboud University Nijmegen and graduated in 1979. As from 1980 untill 2000 , he worked as a general dental practitioner in Best. In the early nineties he started training and education in Maxillofacial Prosthodontics at the Daniël den Hoed Cancer Center in Rotterdam, under the guidance of Leo Visch. Since the year 2000, he is a fulltime maxillofacial prosthodontist at the department of Oral and Maxillofacial Surgery of the University Medical Center in Maastricht. His main interest is the oral and facial rehabilitation of patients who were treated because of head and neck cancer. His research topics are advanced digital technology in head and neck oncology and implant dentistry in irradiated patients. He was many times an invited speaker at several national and international conferences and symposia. His main lecture topics are the application of computer-assisted planning and computerassisted treatments in oral and maxillofacial prosthodontics and implantsupported prostheses in the maxillofacial region, particularly in irradiated patients. 